PNL-6813

UC-2

\title{
Hanford and The Tri-Cities Economy: Review and Outlook, March 1989
}
M. J. Scott
D. M. Beck
D. B. Belzer
R. W. Schultz
S. J. Marsh
S. A. Harkreader

March 1989

Prepared for the U.S. Department of Energy under Contract DE-AC06-76RLO 1830

Pacific Northwest Laboratory Operated for the U.S. Department of Energy by Battelle Memorial Institute 


\title{
DISCLAIMER
}

This report was prepared as an account of work sponsored by an agency of the United States Government. Neither the United States Government nor any agency thereof, nor Battelle Memorial Institute, nor any or the r employees, makes any warranty, expressed or implied, or assumes any legal liability or responsibility for the accuracy, completeness, or usefuiness of any information, apparatus, product, or process disclosed, or represents that its use would not inf ringe privately owned rights. Reference herein to any specific commercial product, process, or service by trade name, trademark, manufacturer, or otherwise does not necessarily constitute or imply its endorsement, recommendation, or favoring by the United States Government or any agency thereof, or Battelle Memoria Institute. The views and opinions of authors expressed herein do not necessarily s:ate or reflect those of the United States Government or any agency thereof.

\author{
PACIFIC NORTHWEST LABORATORY \\ operated by \\ BATTELLE MEMORIAL INSTITUTE \\ for the \\ UNITED STATES DEPARTMENT OF ENERGY \\ under Contract DE-ACO6-76RLO 1830
}

\begin{tabular}{|c|c|}
\hline \multicolumn{2}{|c|}{ Printed in the United States of America } \\
\hline \multicolumn{2}{|c|}{ Available from } \\
\hline \multicolumn{2}{|c|}{ Natisnal Technical Intormation Service } \\
\hline \multicolumn{2}{|c|}{ United Statt's Department of Commerce } \\
\hline \multicolumn{2}{|c|}{5285 Porl Royal Road } \\
\hline \multicolumn{2}{|c|}{ Springtield, Virginia $2216: 1$} \\
\hline \multicolumn{2}{|c|}{ NTIS Price Codes } \\
\hline \multicolumn{2}{|c|}{ Mic rofiche A01 } \\
\hline \multicolumn{2}{|c|}{ Printed Copy } \\
\hline & Price \\
\hline Pages & Codes \\
\hline $001-025$ & $\mathrm{~A} 02$ \\
\hline $026-050$ & $\mathrm{~A} 03$ \\
\hline $051-073$ & $\mathrm{~A} 04$ \\
\hline $076-100$ & $\mathrm{~A} 05$ \\
\hline $107-125$ & A06 \\
\hline $126 \cdot 150$ & $\mathrm{~A} 07$ \\
\hline $151-175$ & $A D B$ \\
\hline $176-200$ & $\mathrm{~A} 09$ \\
\hline $201-225$ & A 10 \\
\hline $226-250$ & A11 \\
\hline $251-275$ & $\mathrm{~A} 12$ \\
\hline $276-300$ & $\mathrm{~A} 13$ \\
\hline
\end{tabular}



M. J. Scott
D. A. Beck
D. B. Belzer
R. W. Schultz
S. J. Marsh
S. A. Harkreader

March 1989

Prepared for the U.S. Department of Energy under Contract DE-AC06-76RLO 1830

Pacific Northwest Laboratory Richland, Washington 99352 
$\cdot$

.

,

. 


\section{ABSTRACT}

The economy of the Tri-Cities, Washington area (primarily, Benton and Franklin Counties) is in transition due to major changes in two Department of Energy programs at Hanford -- the abrupt ending of the Basalt Waste Isolation Project (BWIP) in December 1987 and the placing of the $N$ Reactor in "cold standby" status in February 1988. This report reviews the economic situation in the Tri-Cities during 1988 and presents forecasts for key economic indicators for 1989 . This report will be updated about every six months to review the changes in the area economy and forecast the near-term outlook. 


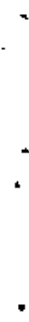




\section{PREFACE}

The federal government's Hanford Site is the major employer in the Tri-Cities Richland, Kennewick, and Pasco and the area encompassed by Benton and Franklin Counties. It is also, by virtue of its size, considered to be a major employer in the state of Washington. In December, 1987 Congress suddenly halted operations on the Basalt Waste Isolation Project (BWIP) at Hanford. In February 1988, the announcement was received that the $N$ Reactor, a key facility at the Site, was to be placed on "cold standby" status. Recognizing that these events would have significant implications for the Tri-Cities region, the Richland Operations Office of the Department of Energy (DOE-RL) and the Office of Economic Adjustment within the Department of Defense (OEA) initiated a three-year study to monitor, analyze, and forecast socioeconomic change in the Tri-Cities. Updates are planned twice a year on the local socioeconomic situation, including both updated data on economic and social impacts that have occurred and a forecast for the following 12 months.

Because this report is the first of its kind in the local area, the authors have had to anticipate the information needs of the report's readers. We welcome your comments and suggestions concerning report content and format. If you have comments or questions, please write Dr. Michael J. Scott, Pacific Northwest Laboratory K6-57, P.0. Box 999, Richland, Washington 99352 or call (509) 376-2458. We will try to incorporate your ideas in subsequent reports. 


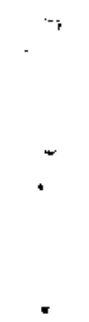

. 
EXECUTIVE SUMMARY

The economy of the Tri-Cities and the surrounding area within Benton and Frankl in Counties is an economy in transition. During the Federal Fiscal Year (FY) 1988, October 1987 through September 1988, the area received two major economic shocks related to the U.S. Department of Energy (DOE) Hanford Site--the abrupt ending of the Basalt Waste Isolation Project (BWIP) and the placing of the $N$ Reactor in "cold standby" status. These economic shocks have adversely affected the local economy during Calendar Year (CY) 1988, and will continue to have an effect throughout CY 1989 and beyond.

The changed status of $N$ Reactor and its potential effect on the local economy was anticipated and was previously discussed in a Pacific Northwest Laboratory (PNL) report entitled The Economic Effects of Closing Hanford's $N$ Reactor and Nuclear Materials Production Facilities (PNL-6295), published in August 1987. However, it focused on the forecasting of impacts of not restarting the $N$ Reactor, which had been shut down for safety improvements. lt did not purport to examine either the loss of the BWIP project or the effects of non-Hanford related changes in the economy of the Tri-Cities region.

CY 1988 proved to be a year of opportunity in the non-Hanford economy. Highlights included new construction projects, an excellent year in agriculture, increases in tourism, increases in the size of the retirement community, and the new location or expansion of several smaller employers in the Tri-Cities. These positive changes in the non-Hanford economy have had the effect of reducing, at least for the current period, the magnitude of economic disruption that otherwise would have been expected to accompany a significant loss of jobs at Hanford.

The question now is whether the relatively moderate impacts observed between the third quarter of 1987 and the fourth quarter of 1988 can be maintained as a result of continued stimulus from the non-Hanford sectors or whether the forces set in motion in early 1988 (including additional job losses at Hanford during 1989) will predominate, leading to more economic adversity in the region. Based on information available in January 1989, we expect the impacts of lower Hanford budgets and employment that began in CY 1988 to continue into CY 1989 and not to be offset to the same degree as in CY 1988. Thus, while the exact timing is uncertain, we expect noticeable job losses to occur in the local service sector beginning about the middle of the CY 1989 and to continue throughout the year.

\section{ES. 1 OVERVIEH OF CY 1988}

CY 1988 was a year of transition. By the first quarter of the year, the Hanford Site had already begun to feel the employment effects of consolidating the Hanford Site contractors from eight to four. More importantly, significant uncertainties hanging over the Department of Energy's programs at the Hanford Site were resolved. In December 1987, the Congress decided to narrow the focus for the nation's high-level nuclear waste repository site 
characterization program to a single site at the Nevada Test Site near Las Vegas, Nevada. This halted the Basalt Waste Isolation Project and the commercial waste isolation mission at Hanford. Associated job losses began to be felt in early CY 1988. In February 1988, citing a surplus of plutonium for defense purposes, the Department of Energy decided to place $\mathrm{N}$ Reactor on cold standby status. The economy began in March 1988 to adjust to the related loss of jobs at the $\mathbf{N}$ Reactor and in the Nuclear Materials Production mission. Partially offsetting these job losses, remediation of the Hanford Site has received increased attention and support.

The non-Hanford economic base has seen stability or growth in most sectors, offsetting some of the unfavorable economic news from Hanford. Offsetting events included a strong increase in agricultural income, tourism expenditures, and the retired population of the area. Minor increases in employment have occurred in Agriculture and Food Processing (Lamb-Weston headquarters employment and Iowa Beef Packers) and other manufacturing (Advanced Nuclear Fuels, Sandvik Special Metals, and Boise Cascade-Wallula). During the fourth quarter, larger increases occurred in regional retailing with the opening of the expanded Columbia Center and nearby coliseum.

Table ES.1 shows changes in quarterly average seasonally adjusted employment by sector in the Tri-Cities economy between third quarter of CY 1987 and fourth quarter of $C Y$ 1988. The first few lines of the table convert the end-of-quarter Hanford employment totals usually reported by DOE into quarterly average seasonally adjusted resident employment figures used in this report. Quarterly average seasonally adjusted figures are used for employment figures throughout this report to smooth out month-to-month fluctuations in employment and present a clearer picture of underlying changes in the local economy. The resident employment concept is used in order to focus on those workers who live in Benton and Franklin Counties. It excludes those workers who work in the two counties but live elsewhere (e.g., Yakima). Individual values in the table are rounded to the nearest 50 workers.

Table ES.l disaggregates employment and employment changes into their basic and service/secondary sector (non-basic) components. Regional economic growth is dependent on basic sector economic activity. The basic sector is comprised of those industries that sell goods and services outside of the area and bring in money from outside the two counties. Besides Hanford, this includes agriculture, food processing, Washington Public Power Supply System (WPPSS), regional retailing and tourist services, and a few other major employers. The service sector consists of the remaining industries, who serve the local population.

As Table ES.I indicates, there have been significant employment decreases at Hanford during CY 1988. Some (but not a11) of these decreases apparently have been reflected in decreased employment in the service industries in Benton and Franklin Counties. The methodology used in the August $1987 \mathrm{~N}$ Reactor Closure Study suggests that, in the long run (approximately 4 years) with no other changes in the non-Hanford basic sector, nearly 2,650 local secondary or service sector jobs could eventually be lost due to the 2,200 resident Hanford jobs lost from the third quarter of CY 1987 to the 
TABLE ES.1. Total Resident Employment, Tri-Cities Area, Recent History

\begin{tabular}{|c|c|c|c|c|c|c|}
\hline \multirow{2}{*}{ Enploment Indicator } & \\
\hline & $\begin{array}{l}\text { Sept. 30, } \\
1987 \\
\end{array}$ & $\begin{array}{l}\text { Dec. 31, } \\
1987 \\
\end{array}$ & $\begin{array}{l}\text { March } 31, \\
1988 \\
\end{array}$ & $\begin{array}{c}\text { June } 30, \\
1988 \\
\end{array}$ & $\begin{array}{l}\text { Sept. 30, } \\
1988 \\
\end{array}$ & $\begin{array}{l}\text { Dec. } 31, \\
1988 \\
\end{array}$ \\
\hline \multicolumn{7}{|l|}{ Darterly Average Residemt Employment: } \\
\hline $\begin{array}{l}\text { Henford End-of-Ouarter Enployment } \\
\text { Hanford Querterly Averege Employment } \\
\text { Less: Not Resident }\end{array}$ & $\begin{array}{l}14,500 \\
14,600 \\
-1,150\end{array}$ & $\begin{array}{l}14,100 \\
14,300 \\
-1,150\end{array}$ & $\begin{array}{l}13,500 \\
13,900 \\
-1,100\end{array}$ & $\begin{array}{l}12,900 \\
13,150 \\
-1,050\end{array}$ & $\begin{array}{l}12,400 \\
12,600 \\
-1,050\end{array}$ & $\begin{array}{l}12,200 \\
12,00 \\
-1,000\end{array}$ \\
\hline Henford Aversge Quarterly Resident Employment & 13,450 & 13.150 & 12,800 & 12,100 & 11,550 & $11, \mathbf{5 0}$ \\
\hline Morr Hanford Basic sector & 17.950 & 18.000 & 18,100 & 18,100 & 18,100 & 18,600 \\
\hline Subtotal & 31,400 & 31,150 & 30,900 & 30,200 & 29,650 & 29,650 \\
\hline $\begin{array}{l}\text { Service Industries (Secondary) } \\
\text { Total Resident Emplomment }\end{array}$ & $\frac{31,800}{63,200}$ & $\frac{32,000}{63,150}$ & $\frac{31.850}{62,750}$ & $\frac{31,200}{61,400}$ & $\frac{31,300}{60,950}$ & $\frac{31,300}{60,950}$ \\
\hline \multicolumn{7}{|l|}{ Cumulative Net Change } \\
\hline $\begin{array}{l}\text { Henford And Procuresents } \\
\text { Other Basic } \\
\text { Service Sector (Secondery) } \\
\text { Total }\end{array}$ & $\begin{array}{l}0 \\
0 \\
0 \\
0\end{array}$ & $\begin{array}{r}-300 \\
50 \\
200 \\
-50\end{array}$ & $\begin{array}{r}-650 \\
150 \\
50 \\
-450\end{array}$ & $\begin{array}{r}-1350 \\
150 \\
-600 \\
-1800\end{array}$ & $\begin{array}{r}-19000 \\
150 \\
-500 \\
-2250\end{array}$ & $\begin{array}{r}-2200 \\
450 \\
-500 \\
-2250\end{array}$ \\
\hline
\end{tabular}

fourth quarter of CY 1988 , a ratio of 1.2 service sector jobs to 1 Hanford job. However, owing to the successful management measures that delayed the Hanford job losses to reduce their adverse economic impact (and reduce the multiplier effect in the short run), the methodology projects that only about 1,000 of the total 2,650 potential job losses should have been expected by the fourth quarter of 1988, with the balance occurring in 1989 and beyond. Fortunately, the positive developments in the rest of the basic sector (including an increase of 450 employees) offset about 450 to 500 of these 1,000 potential lost service sector jobs. Overall, on a quarterly average basis, the employment changes over the period were: Hanford, down 2200 residents (from 13,450 to 11,250); non-Hanford basic, up 450 (from 17,950 to 18,400 ); service sector, down 500 (from 31,800 to 31,300 ), for a total net loss of 2,250 jobs. Average employment through the first three quarters was down $2.1 \%$ compared with 1987 . (In the state as a whole, average resident employment was up by $4.4 \%$ through the third quarter.)

The year 1988 al so saw other symptoms of a weaker local economy. Personal income in Benton and Franklin Counties (measured in constant 1988 dollars) fell, from $\$ 2.14$ billion in CY 1987 to between $\$ 2.10$ and $\$ 2.09$ bil7 ion in CY 1988, a loss of about $2.2 \%$. The earnings component was down $3.7 \%$ through the third quarter. (In contrast, the earnings component of State of washington personal income was up about $1.5 \%$ through the third quarter.) The average selling price of a single family home in the Tri-Cities fell by about 2.5\% during $\mathrm{CY} 1988$, al though the price had stabilized or risen during most of the second half of the year. As a group, local school districts sustained a net enrollment loss by the fall of 1988, a loss that would have been larger but for influx of kindergartners in Xennewick. The local area probably lost population as well due to outmigration. 
Movements in local tax bases have been mixed. Based on partial data through the third quarter of $\mathrm{CY}$ 1988, all local jurisdictions saw losses in their assessed values compared with a year earlier, while Kennewick's sales and use tax bases grew. Most other jurisdictions' sales and use tax bases appeared to either be down or roughly constant relative to CY 1987 .

\section{ES.2 NEXT 12 MONTHS}

The experience through the end of December, 1988 indicates that the loss of Hanford resident jobs was not met by the approximately proportional reduction in secondary jobs that would have been expected. The question that must be addressed is whether in the twelve months from January through December 1989 the forces set in motion as a result of the significant number of jobs lost at Hanford in the preceding five quarters will, together with the additional Hanford losses predicted in the forthcoming four quarters, overwhelm the offsetting influence of employment increases elsewhere in the local economy and result in significant net reductions in secondary employment.

Based upon the data gathered as a result of monitoring events during the preceding five quarters and the best estimates of economic activity in the Hanford and non-Hanford basic sectors of the economy, we expect to see continued reaction of the local economy to the reductions in force that have al ready occurred at Hanford, as well as the effects of some additional 300 to 650 resident Hanford jobs that are expected to be lost through redyctions in force and/or early retirements through the fourth quarter of 1989 . (d) (The number of Hanford jobs lost will depend upon Congressional actions that cannot be predicted at this time. Significant additional funding for site restoration is currently pending Congressional action. Approval would favorably influence the current employment forecast.) offsetting this to some degree will be the impact of the recentiy arrived headquarters of LambWeston, Inc., Cascade Columbia Foods, and increased regional retailing activity of the Columbia Center and nearby businesses.

Our predictions for CY 1989 assumed the following:

- The farm economy will remain strong but will not grow further.

- Food processing employment will increase by 100 due to the new Cascade Columbia food processing plant starting operation.

- There will be little increase in employment at other major employers (about 50 jobs).

(a) DOE, working on fiscal year basis, and discussing end-of-year magnitudes rather than averages, indicates that the FY 1989 losses will be 500 to 900 jobs. The DOE numbers are equivalent to those used in this forecast. About 200 of the projected DOE losses already occurred between September 30 and December 31,1988 . The remaining differences are due to quarterly averaging and to residency adjustments. 
- About 200 of the new jobs associated with the Columbia Center Expansion are assumed to be part of the community's "export" sector; that is, supported by shoppers outside of the Tri-cities. This number is assumed to grow by about 25\% in 1989.

- Total government payments to retirees will increase by about 3.5\%, as in recent years.

Table ES.2 summarizes the forecasts of some of the more significant economic indicators for $C Y$ 1989. Based upon the assumptions above, total non-basic Hanford employment is projected to increase by about 200 between the fourth quarter of 1988 and the fourth quarter of 1989 . The secondary sector, however, continues to experience job losses from the ongoing repercussions of the 1988 Hanford job losses, plus the expected Hanford reductions during 1989. Assuming the smaller number of Hanford reductions (the "high employment" case in Table ES.2), secondary employment is projected to fall

IABLE ES.2. Forecasts of Significant Economic Indicators, Benton and Frank1 in Counties, October 1988-December 1989

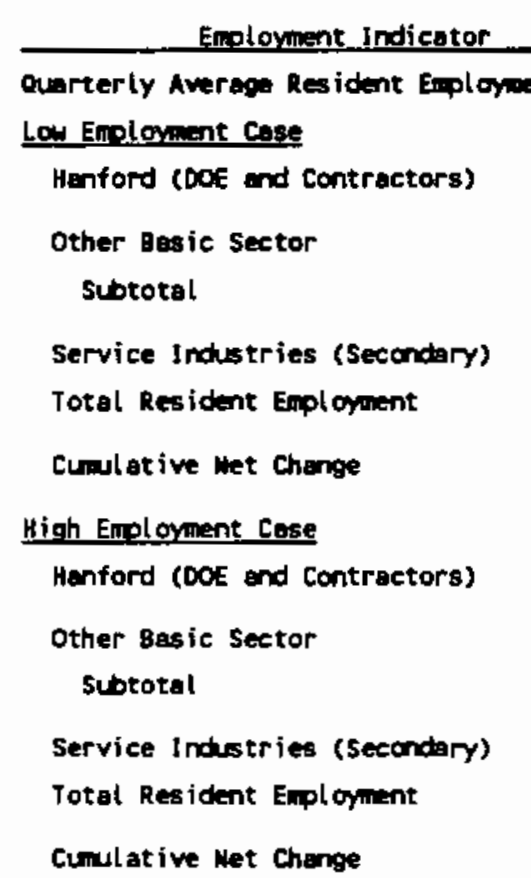

Personal Income, Benton and Frerklin counties (Anual Rate, Hillions of 1998 s)

Resident Population, Benton and Frankl in Counties (Aprit 1)

Single Family Housing Price

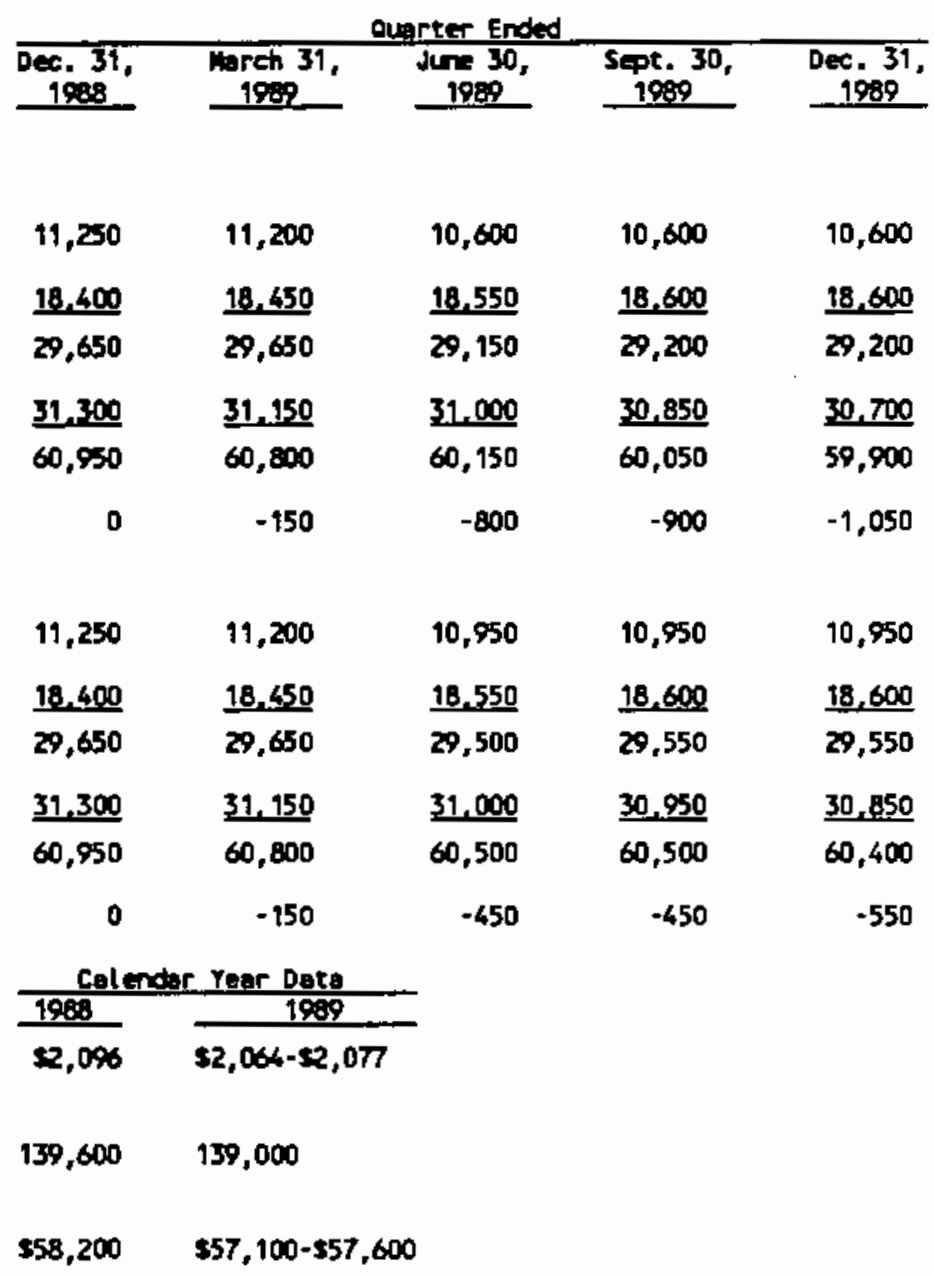


by 450 . Total area employment would fall in this case by 550 (-300 at Hanford, +200 in other basic, -450 secondary). Using the 1 arger estimates of Hanford job losses (the "low employment" case in the table), total Benton and Franklin County employment is projected to fall by 1,050 (-650 Hanford, +200 other basic, -600 secondary) .

Personal income in the two-county area is expected to fall by 0.9 to $1.5 \%$ after inflation, even though farm income will remain high for a second year in a row and government transfers to a growing retired population will increase by 3 to $4 \%$ in 1989 . This loss in overall income of the area will be reflected in weakening of retail sales and housing markets. A drop in retail sales and construction would reduce local tax revenues. Based on weaker income and the possibility of higher interest rates in 1989, Table ES.2 shows a decline of about 1 to $2 \%$ in average housing prices in the Tri-Cities during 1989. Although undesirable for current owners, lower housing and land costs may help attract additional businesses or retirees to the area.

We do not expect the lower-paying jobs currently being created elsewhere in the basic sector to entirely make up for the Hanford-related losses. Unless there is a further substantial increase in non-Hanford basic sector activity or an upturn in Hanford programs during CY 1989, we expect that the service sector losses will continue into 1990 as the multiplier effects play themselves out.

In summary, even if the expected positive developments outside of Hanford are fully realized, they are unlikely to completely offset the delayed repercussions of the 1988 layoffs and the 1989 job losses at Hanford. The Tri-City labor market, while displaying hopeful signs of long-term rebound as diversification proceeds, can be expected to be weaker a year from now than it is today. 


\section{CONTENTS}

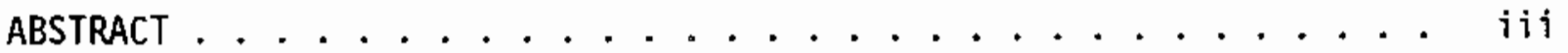

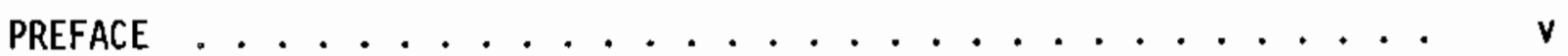

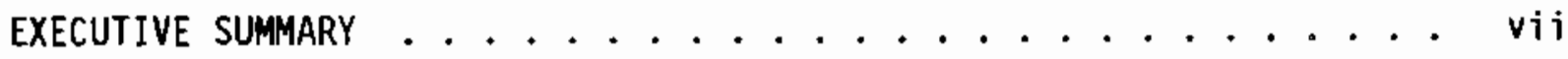

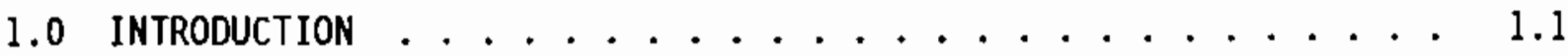

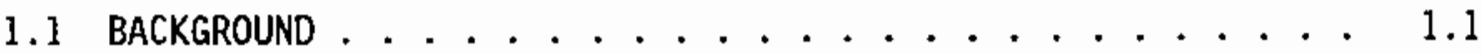

1.2 FEDERAL ACTIONS DURING OCTO8ER 1987-DECEMBER $1988 \ldots 1.2$

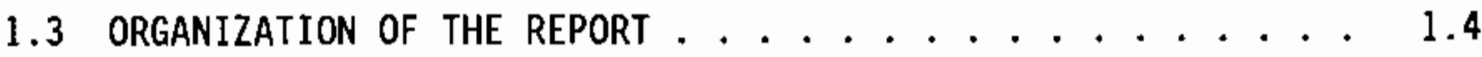

2.0 THE TRI-CITIES ECONOMY, OCTOBER 1987-DECEMBER $1988 \ldots \ldots 2.1$

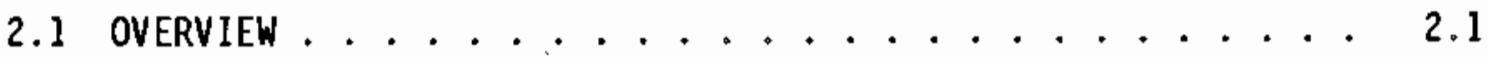

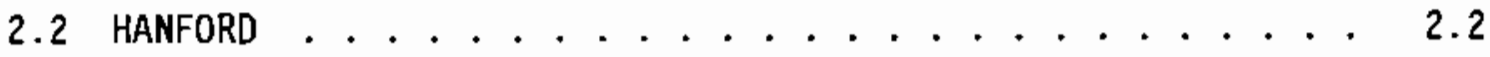

2.3 OTHER BASIC INDUSTRY . . . . . . . . . . . . . . . 2.4

2.4 STATE AND LOCAL EMPLOYMENT AND INCOME $\ldots \ldots \ldots \ldots$

2.4.1 Quarterly Employment by Sector ......... 2.8

2.4.2 Analysis of Recent Employment Changes . . . . 2. 2.9

2.5 POPULATION AND HOUSING ......................... 2.10

2.6 TRADE AND UTILITIES . . . . . . . . . . . 2.16

2.7 TAX BASE OF STATE AND LOCAL GOVERNMENT . . . . . . . . 2.17

2.8 PUBLIC SERVICE DEMANDS . . . . . . . . . . . . 2.19

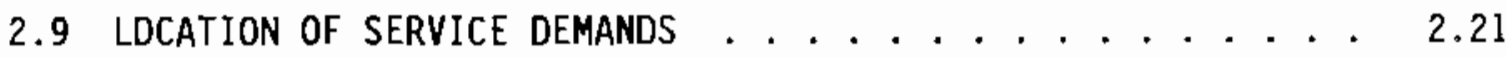

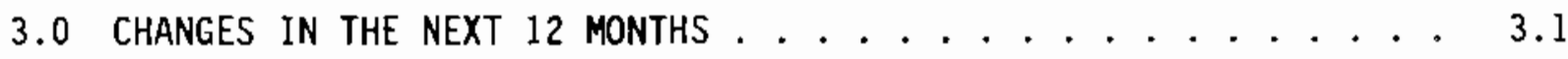

3.1 EXPECTED DEVELOPMENTS AT HANFORD DURING $1989 \ldots \ldots$

3.2 PROJECTED EMPLOYMENT IN THE TRI-CITIES . . . . . . 3.2

3.2.1 The Non-Hanford Basic Sector ........ 3.2

3.2.2 Projected Employment by Major Sector . . . . . 3.3

3.2 .3 offsetting Factors ........... 3.5 
3.2 .4 Personal Income . . . . . . . . . . 3.5 3.3 POPULATION $\ldots \ldots \ldots \ldots \ldots$

3.4 PROJECTEd hOUSING VALUES . . . . . . . . . . 3.8 4.0 REFERENCES ........................... 4.1 APPENDIX A - METHODOLOGY FDR EMPLOYMENT AND POPULATION FORECASTS . . . A.1 APPENDIX B - SURVEY DESIGN . . . . . . . . . . . . B.I APPENDIX C - DETAILS DF HANFORD EMPLOYMENT FORECAST . . . . . c c.1 


\section{FIGURES}

ES.1 Recent History and Forecast of Employment in Benton and Franklin Counties for January 1989-December 1989 . . . . . . . xi

2.1 Index of Selling Price for Single Family Houses in Tri-Cities Real Estate Market, 1977-1988 . . . . . . . . . 2.13

2.2 Indexes of Tri-Cities Area Taxable Retail Sales and Residential Telephone Utility Customers by Calendar Year, 1979-1988 . . . 2.17

A.1 Time-Phased Employment Multiplier . . . . . . . . . . . . A.6

B.l Original Hanford Worker Exit Survey Form . . . . . . . . . . B.2

B.2 Redesigned Hanford Worker Exit Survey Form . . . . . . . . . . . B.4 


\section{IABLES}

ES.I Total Resident Employment, Tri-Cities Area, Recent History . . ix

ES.2 Forecasts of Significant Economic Indicators, Benton and Frankl in Counties, October 1988-December 1989 ...... xi

1.1 Chronology of Key Hanford Events and Corresponding

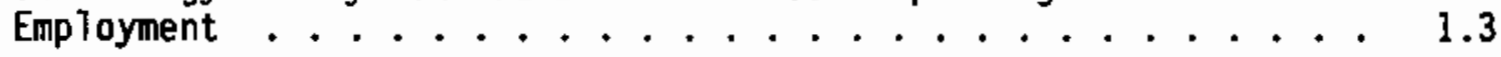

2.1 Hanford End-of-Year Employment, Payroll, Procurement, and Calendar Year Taxes, 1986 Through $1988 \ldots \ldots . \ldots 2$

2.2 End-of-Quarter Hanford Employment by Program and Quarter, Through the End of $\mathrm{CY} 1988 \ldots \ldots . . \ldots 2.3$

2.3 Characteristics of Former Hanford Employees Involved in Hanford Employment Reductions at Westinghouse Hanford

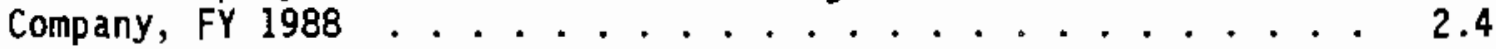

2.4 State and County Employment and Real Earnings, 1986, 1987 and Average for the First Nine Months of 1988 . . . . . . 2.8

2.5 Total Resident Employment, Tri-Cities Area, Recent History . . 2.8

2.6 Benton and Franklin County Resident Population, 1986

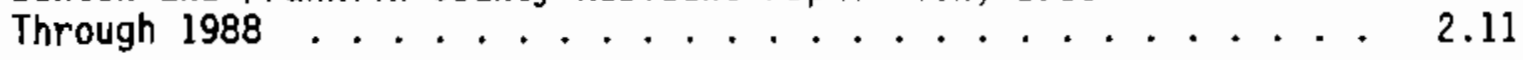

2.7 Population Changes, 1987 to September 1988, Based on Residential Telephone Customers ............. 2.11

2.8 School District Enrollments, 1987 and 1988 School Years . . . 2.12

2.9 Population Change, 8uilding Permits, and Vacancy Rates in Tri-Cities Rea] Estate Market, 1975-1988 ......... 2.14

2.10 Tri-Cities Population Change, Mortgage Interest Rates, Sales Volume and Average Selling Prices of Housing Units in the Tri-Cities Real Estate Market, by Calendar Year, 1978-1988 . . 2.15

2.11 Tri-Cities New Residential Construction, by Calendar Year, 1978 to 1988

2.12 Sales, Use, and Property Tax Base by Jurisdiction, and Calendar Year, Tri-Cities Area, 1981-1988 ........ 2.18

2.13 Annual Average Case Loads, Selected Social Service Functions in the Tri-Citjes Area, by Calendar Year, 1984-1988..... 2.20

2.14 Residence of Departing Hanford Workers Compared with Predicted Values, May 9-November 11, 1988. 
2.15 Residence of Exiting Hanford Workers Based on Westinghouse Hanford Company and Kaiser Engineers Hanford Company

Employment Records, January 1, 1988 to August 21, 1988 . . . . . 2.23

3.1 Anticipated Changes at the Hanford Reservation, Recent History and Next Tweive Months .............. 3. . . . .

3.2 Total Resident Employment, Tri-Cities Area, Recent History and Next Twelve Months, High Employment Case, Seasonaliy Adjusted ........................

3.3 Total Resident Employment, Tri-Cities Area, Recent History and Next Twelve Months, Low Employment Case, Seasonally Adjusted ....................... 3.4

3.4 Wage and Salary Income and Total Personal Income . . . . . . 3.6

3.5 Benton and Franklin County Population, History and Projections................... . . . 3.7

3.6 Changes in Tri-Cities Area Population: Recent History and Next Two Years, Low Employment Case............ 3.8

A.1 Comparison of Basic and Secondary Employment, 1986 Versus Third Quarter 1987

A.2 Total Employment and Seasonal Factors for Benton and Frankl in Counties, 1987-1988 ..............

A.3 Secondary Employment: Impact Versus Forecast, 1987:3 Through

A.4 Total Resident and Nonagricultural Jobs--Recent Monthly Estimates ................... A.14

A.5 Fourth-Quarter Change in Nonagriculture Employment, Fourth-Quarter 1987--Fourth-Quarter 1988

A.6 Components of Change in Personal Income, 1987-1988 and 1988-1989, Low Employment Case . . . . . . . . . . . . . .

A.7 Population and Employment Changes in Benton and Franklin Counties, 1980-1988

A.8 Use of Time-Phased Multipliers to Project Migration from

C.l Forecast of Hanford Site Employment Program, February 1988 


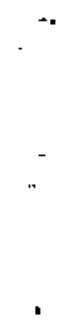




\subsection{INTRODUCTION}

This report was prepared at Pacific Northwest Laboratory, Richland, Washington. PNL is operated for the Department of Energy, Richland Operations (DOE-RL) by Battelle Memorial Institute. The report follows up on work done for DOE-RL on economic impacts of changes at Hanford, which was pub1 ished in August 1987 as The Economic Effects of Closing Hanford's N Reactor and Nuclear Materials Production Facilities (PNL-6295). The study that produced this report was requested and is being funded by DOE-RL and the office of Economic Adjustment in the U.S. Department of Defense.

\subsection{BACKGROUND}

The Tri-Cities Socioeconomic Monitoring and Analysis Study is part of a broad strategic planning effort to better understand and quant ify the role and importance of the Hanford mission to the State and regional economies. Specifically, this study will track the changes occurring at Hanford and elsewhere within the economy of the Tri-Cities area and document the effects that these changes have on the local and state economies. Using these data, this study will also provide near-real-time forecasts of the effects expected within the next tweive months. These forecasts will be of use to State agencies, affected local jurisdictions, and other organizations in preparing for and managing the anticipated changes in employment, population, economic activity, and public services and revenues.

The Tri-Cities Socioeconomic Monitoring and Analysis Study builds upon the socioeconomic information base that was originally developed in the N Reactor Closure Study and the Basalt Waste Isolation Program (BWIP) socioeconomic studies. The current effort focuses in more detail on the nearterm impacts occurring locally as a result of cancellation of BWIP and the declining activity at the $N$ Reactor, as well as other changes occurring in the non-Hanford economy.

Specifically, we will produce a semiannual monitoring and analysis report during the next three Federal fiscal years documenting the actual changes occurring in employment, population, private economic activity, and selected community services.

We will use the actual changes observed in the local area to make up-todate projections of the impacts expected to occur within the next four calendar quarters. Thus, all interested users of the report will have available to them a consistent set of continually updated data and projections with which to manage the effects of changes in the Tri-Cities economy.

We also plan to provide empirical data on the social impacts experienced, which will allow projections to be made of the retraining and social support needs of impacted workers and their families. State and local educational and social service agencies need this information to anticipate what retraining and services will be required as Hanford layoffs proceed. Currently these agencies lack some of the necessary detailed data with which to 
plan. For instance, no one knows how many people who lose their jobs will decide to stay in the area. Gathering this information will benefit community agencies who are currentiy trying to design mitigation programs.

Such information also serves a future local and perhaps even a national purpose. It provides DOE with a documented example that can be referred to in responding to future community concerns when plants are built, closed, or placed on standby. Therefore, our goal with the current study is to provide as much information as possible concerning changes in the Tri-Cities population as they occur, and to forecast these changes and their impacts as accurately as possible.

\subsection{FEDERAL ACTIONS DURING OCTOBER 1987-DECEMBER_1988}

In December 1987, Congress decided to halt further studies at the Basalt Waste Isolation Project, a major Hanford activity that employed approximately 1,300 workers at the end of FY 1987 (September 30, 1987). BWIP was rapidly reduced in size. By the end of FY 1988 (September 30, 1988) it employed only about 200 people. Employment at BWIP is expected to fall to about 50 persons by the end of FY 1989 (see Appendix C).

In February, 1988, citing the 1ack of need for plutonium, the Department of Energy announced that it was placing the $\mathbf{N}$ Reactor on cold standby status. Cold standby means that the reactor is ready to start but not expected to operate except in an emergency. Thus, the Hanford Site defense production mission has significantly declined in importance. The work force in the Hanford Nuclear Materials Production mission has declined from 6,400 at the end of FY 1987 to 5,100 at the end of FY 1988 (September 30, 1988), a loss of 1,300 . The change in the status of $\mathbf{N}$ Reactor is expected to result in the loss of 2,200 to 2,300 cumulative jobs at Hanford by the end of FY 1989 (September 30, 1989) (see Appendix C).

Increases in activity related to defense waste storage began to occur in FY 1988 that will partially mitigate the adverse impact of the two major closures. Hanford environmental remediation programs have begun to accelerate, resulting in an increase in employment in the Hanford Defense Waste Mission from 2,900 at the end of FY 1987 to 3,200 at the end of FY 1988. Further increases are expected, with defense waste jobs climbing to 3,450 to 3,650 at the end of FY 1989 (see Appendix C).

These changes in end-of-quarter job totals at Hanford translate into changes in the quarterly average employment in Benton and Frank1 in Counties. Quarterly average seasonally-adjusted resident employment is used in this report to analyze local economic change because some of the local industries such as agriculture are characterized by random monthly variation and regular seasonal cycles in employment that do not reflect any underlying economic change and would not be expected to affect service sector economic activity. Resident employment is used to account for the fact that Tri-Cities residents work outside of the Benton and Franklin Counties at businesses such as BoiseCascade at Wallula (Walla Walla County), but spend their paychecks in the Tri-Cities, affecting the Benton and Frank1 in Counties' service sector. At 
the same time, residents of Yakima County and other count ies who work at Hanford are more likely to spend their paychecks where they live and are less likely to affect 1ocal Tri-Cities employment.

Table 1.1 gives a chronology of key events at Hanford since September 30,1987 and shows the corresponding effect on end-of-quarter employment, average employment for the quarter, and average resident employment for the quarter.

TABLE_1.1. Chronology of Key Hanford Events and Corresponding Employment

\begin{tabular}{|c|c|c|c|c|}
\hline $\operatorname{Date}(s)$ & Event & $\begin{array}{l}\text { End-of- } \\
\text { Quarter } \\
\text { Hanford } \\
\text { Employment }\end{array}$ & $\begin{array}{c}\text { Average } \\
\text { Hanford } \\
\text { Employment } \\
\text { During Ouarter }\end{array}$ & $\begin{array}{c}\text { Average } \\
\text { Hanford } \\
\text { Resident } \\
\text { Employment } \\
\text { During Quarter }\end{array}$ \\
\hline $\begin{array}{l}\text { September } 30 \text {, } \\
1987\end{array}$ & End of FY 1987 & 14,500 & 14,600 & 13,450 \\
\hline $\begin{array}{l}\text { October- } \\
\text { December } \\
1987\end{array}$ & $\begin{array}{l}\text { Announced End of } \\
\text { 8WIP; Hanford Site } \\
\text { Consol idation }\end{array}$ & 14,100 & 14,300 & 13,150 \\
\hline $\begin{array}{l}\text { January- } \\
\text { March } \\
1988\end{array}$ & $\begin{array}{l}\text { Announcement of } \\
\text { Cold Standby for } \\
\text { N Reactor; Major } \\
\text { BWIP Job Losses }\end{array}$ & 13,500 & 13,900 & 12,800 \\
\hline $\begin{array}{l}\text { March-June } \\
1988\end{array}$ & $\begin{array}{l}\text { First Major } \\
\text { N Reactor Job } \\
\text { Losses; BWIP Job } \\
\text { Losses Cont inue }\end{array}$ & 12,900 & 13,150 & 12,100 \\
\hline $\begin{array}{l}\text { July- } \\
\text { September } \\
1988\end{array}$ & $\begin{array}{l}\text { Voluntary Early } \\
\text { Retirement Incen- } \\
\text { tives; N Reactor } \\
\text { Job Losses } \\
\text { Continue }\end{array}$ & 12,400 & 12,600 & 11,550 \\
\hline $\begin{array}{l}\text { October- } \\
\text { December } \\
1988\end{array}$ & $\begin{array}{l}\text { Additional Hanford } \\
\text { Job Losses }\end{array}$ & 12,200 & 12,250 & 11,250 \\
\hline
\end{tabular}

Sources: Calculated from data supplied by DOE-RL. 


\subsection{ORGANIZATION OF THE REPORT}

The remainder of this report is organized as follows. Section 2.0 describes the Tri-Cities economy and economic and socjal impacts that have occurred during the period September 1987 through December 1988 . Section 3.0 discusses our forecasts for the Tri-Cities over the next year (CY 1989). The report concludes with appendices discussing the methods used in the forecasts, the Hanford Worker Exit Survey being used to gather data on departing Hanford workers, and the latest DOE forecast of Hanford employment. 


\subsection{THE TRI-CITIES ECONOMY, OCTOBER 1987-DECEMBER 1988}

\subsection{OVERVIEW}

The Tri-Cities economy has now gone through the loss of the nuclear repository mission (Basalt Waste Isolation Project) and the first round of layoffs associated with shutdown of Hanford's $\mathrm{N}$ reactor. Approximately 2100 resident and nonresident positions were lost at Hanford between September 30, 1987 and September 30,1988. About 200 more were lost by December 31, 1988. The cumulative loss in resident Hanford employment from September 30, 1987 through December 31, 1988 has been 2200 jobs. At first gl ance, the corresponding response of the Tri-Cities economy has been less than expected, with about 500 resident job losses occurring thus far in the service sector through the quarter ending in December 31, 1988. Most of the losses appear to be in businesses directly supporting Hanford (e.g. architectural services, hotel and motel services) or in the public sector (e.g. the school districts and Benton County). Retail trade has shown few job losses and Tri-Cities taxable retail trade volume through September was actually up over the volume of a year ago.

We do not believe that this negates the importance of the Hanford Site job losses. Even with the large number of early retirements represented in the Hanford job losses, the direct loss of a projected \$80-plus million in annual payroll will have an effect, and we expect the effect to become clearer in the next six months. In a very real sense, the economy is waiting for "the other shoe to fall." (Our projections of total Tri-Cities employment for 1989 are discussed in Section 3.0.)

To complicate matters, during the last year the Tri-Cities service economy appears to have undergone a transition from a largely locally-based econony to a more resilient regionally-based one. The evidence for this is not conclusive; yet, we can point out indicators that the change has occurred.

First, there is the expansion of the Columbia Center mal1, the nearby location of a Costco store and a sports and special events coljseum, and the current construction of a Shopko store in the face of lost activity at Hanford. The reasons the investing firms give for this expansion indicate that major regional and national retailers are responding in part to the need for a regional retail center in the mid-Columbia region.

Second, the geographical reach of the local retajl sector seems to have increased. For example, Columbia Center mall merchants now indicate that they are drawing more of their customers from the Yakima and Pendleton areas. Perhaps even more important, some believe that they are now capturing a portion (perhaps 10-15\%, according to one estimate) of the local retail business that used to go to Seattle, Spokane, Yakima, or Portland. The rise in value of Kennewick's local taxable retail sales in 1988 may support this hypothesis.

If the transition is actually occurring, it is very important. What it portends is that the retail sector itself will begin to act as part of the 
economic base and will be less sensitive to major changes at Hanford. The Northwest Regional Autoplex in Pasco also draws a significant proportion (approximately one-fourth) of its $\$ 100$ million dollars in annual business from outside the local area, further regionalizing the local retail base. What this means is that a significant fraction of the jobs formerly dependent on Hanford and other basic sector activities for their continued existence are being transformed into basic sector jobs responsible directly for attracting dollars to the region from outside the Benton/Franklin County area.

\subsection{HANFORD}

Tables 2.1 through 2.3 provide key data on Hanford employment and financial status relevant to a discussion of the recent economic impacts. Data on declines in Hanford employment, payroll, procurement, and taxes for recent years is provided in Table 2.1. Note the distinction between fiscal years (October-September) and calendar years within the table. Table 2.2 shows Hanford end-of-quarter employment at the end of FY 1987 and for each quarter of FY 1988 by mission. It depicts the phasing down of Nuclear Materials Production ( $N$ Reactor) and BWIP, together with increased activity in defense

TABLE 2.1. Hanford End-of-Year Empioyment, Payro11, Procurement, and Calendar Year Taxes, 1986 Through 1988 (dollars in millions)

\begin{tabular}{|c|c|c|c|}
\hline & $\begin{array}{c}\text { September } \\
1986 \\
\end{array}$ & $\begin{array}{c}\text { September } \\
1987 \\
\end{array}$ & $\begin{array}{c}\text { September } \\
1988 \\
\end{array}$ \\
\hline \multirow[t]{2}{*}{$\begin{array}{l}\text { Budget (fiscal year) } \\
\text { Employment (end of fiscal year) } \\
\text { Annual Payroll (a) } \\
\text { Procurements in Washington State }\end{array}$} & $\begin{array}{r}\$ 1,010 \\
14,500 \\
\$ 505 \\
\$ 151\end{array}$ & $\begin{array}{r}\$ 1,053 \\
14,500 \\
\$ 505 \\
\$ 122\end{array}$ & $\begin{array}{r}\$ 930 \\
12,400 \\
\$ 448 \\
\$ 96\end{array}$ \\
\hline & 1986 & 1987 & 1988 \\
\hline $\begin{array}{l}\text { State Taxes and Fees Paid } \\
\text { By DOE and Hanford Contractors } \\
\text { By Employees (estimate) }\end{array}$ & $\begin{array}{r}\$ 12.5 \\
30.0 \\
\end{array}$ & $\begin{array}{r}\$ 10.8 \\
30.1 \\
\end{array}$ & $\begin{array}{r}\$ 10.9 \\
27.0 \\
\end{array}$ \\
\hline Total & $\$ 42.5$ & $\$ 40.9$ & $\$ 37.9$ \\
\hline $\begin{array}{l}\text { Local Taxes and Fees Paid } \\
\text { By DOE and Hanford Contractors } \\
\text { By Employees (est imate) }\end{array}$ & $\begin{array}{r}\$ 0.9 \\
22.1 \\
\end{array}$ & $\begin{array}{r}\$ 0.9 \\
22.4 \\
\end{array}$ & $\begin{array}{r}\$ 0.9 \\
20.2 \\
\end{array}$ \\
\hline Total & $\$ 23.0$ & $\$ 23.3$ & $\$ 21.1$ \\
\hline
\end{tabular}

(a) Converted to annual basis, based on fiscal year-end employment and wage level.

Source: Calculated from data supplied by DOE and Hanford contractors. 
TABLE 2.2. End-of-Quarter Hanford Employment (a) by Program and Quarter, Through the End of $\mathrm{CY} 1988$

\begin{tabular}{|c|c|c|c|c|c|c|}
\hline & $\begin{array}{l}\text { Sept. 30, } \\
1987 \\
\end{array}$ & $\begin{array}{l}\text { Dec. 31, } \\
1987 \\
\end{array}$ & $\begin{array}{l}\text { Merch 31, } \\
1988 \\
\end{array}$ & $\begin{array}{r}\text { June 30, } \\
1988 \\
\end{array}$ & $\begin{array}{c}\text { Sept. } 30, \\
1988 \\
\end{array}$ & $\begin{array}{l}\text { Dec. 31, } \\
1988 \\
\end{array}$ \\
\hline Nuclear Materials Production & 6,400 & 6,200 & 6,100 & 5,600 & 5,100 & 5,000 \\
\hline Defense Was te Managenent & 2,900 & 3,000 & 3,100 & 3,200 & 3,200 & 3,200 \\
\hline $\begin{array}{l}\text { Basalt thaste lsolation } \\
\text { Project }\end{array}$ & 1,300 & 1,000 & 400 & 200 & 200 & 100 \\
\hline Nuclear Energy R\&D & 1,300 & 1,300 & 1,300 & 1,300 & 1,300 & 1,300 \\
\hline Other & 2,600 & 2,600 & 2,600 & 2,600 & 2,600 & 2,600 \\
\hline $\begin{array}{l}\text { Total Henford (resident } \\
\text { plus nonresident) }\end{array}$ & 14,500 & 14,100 & 13,500 & 12,900 & 12,400 & 12,200 \\
\hline
\end{tabular}

(a) Quarterly average resident employment used for forecasting in section 3.0 is not availeble by mission. Source: DOE Richland Operations office.

waste management. Net losses in jobs totalled 2,200 to the end of CY 1988 year. Quarterly average resident employment, which is used for forecasting in this report, is not available on a mission-by-mission basis.

Table 2.3 provides a preliminary indication of the probable plans of former Westinghouse Hanford Company (Westinghouse Hanford) employees leaving employment at Hanford between May 1988 and early November 1988 . The Hanford Worker exit survey was also administered to departing employees of the site contractors other than Westinghouse, but the response rates for the other contractors were either very low (well under 50\%) or very uncertain (no information on the total number of persons receiving the questionnaire) or both. The response rate for Westinghouse Hanford was about $84 \%$, so this body of questionnaires was considered to be statistically representative of the underlying population. There also was some ambiguity in the wording of several of the questions that has caused difficulty in both responding to the questionnaire and in interpreting the answers. Table 2.3 interprets the answers of those actually answering the locational questions according to the most likely intentions of the respondents. The results should be considered suggestive rather than definitive; however it does appear from the table that retirees are far more likely to stay in the Tri-Cities than those quitting or being laid off.

While a significant number of employees left the Hanford Site between January 1988 and May 1988, the Hanford Worker exit survey form was not yet in the field. A separate body of information was collected on 836 of these former staff members employed by the Westinghouse Hanford Company at BWIP, most of whom were reductions in force or quits rather than retirees.

(a) Data were supplied to this study by the Westinghouse Hanford Company Human Resources Department. 
IABLE 2.3. Characteristics of Former Hanford Employees Involved in Hanford Employment Reductions at Westinghouse Hanford Company, FY 1988 (a)

\author{
Retired \\ Planning to stay in area \\ Planning to leave area \\ Plans uncertain \\ Subtota1 \\ Voluntary quit \\ Planning to stay in area \\ Planning to leave \\ Plans uncertain \\ Subtota]
Reduction of Force
PTanning to stay in area
Planning to leave area
Plans uncertain \\ Subtotal \\ Other Reductions (other reason given for \\ leaving, or residential preference left \\ blank)
}

Total
Percent

Number of Total

\begin{tabular}{rr}
81 & 75.0 \\
17 & 15.7 \\
10 & 9.2 \\
\hline 108 &
\end{tabular}

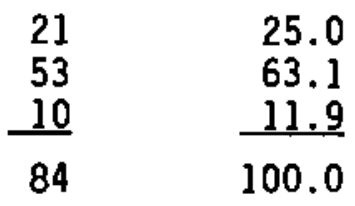

\begin{tabular}{rr}
90 & 27.4 \\
207 & 63.1 \\
31 & 9.5 \\
\hline 328 & 100.0
\end{tabular}

87

607

(a) Estimated from Hanford Worker Exit Survey, Westinghouse Hanford Company. Results May 9,1988 through November 11, 1988. Plans of retired based on retirement question. Plans of voluntary quits and ROFs based on residential preference.

About 382 or $45.7 \%$ were reemployed by other Hanford programs. of the remainder, 43 or $5.1 \%$ were employed elsewhere in the Tri-Cities area, 17 or $2 \%$ retired in the Tri-Cities area and 250 or $29.9 \%$ left the area. Not enough data were available to determine the location of $17.2 \%$ of the tota], a] though some were known to be employed or in school. No information is available to link staff members' stated plans to their subsequent actual decisions regarding whether or not to relocate.

\subsection{OTHER BASIC INDUSTRY}

As described in PNL's 1987 analysis of potential economic impacts of the closure of the $N$ Reactor, the procedure used to analyze employment changes 
distinguishes between a basic sector of the economy and a secondary or service sector. The basic sector includes those businesses that sell goods and services outside Benton or Frankl in County. The secondary sector is essentially a support sector; it sells goods and services locally to those involved in the basic sector and to others in the secondary sector. Although Hanford is the largest single component of the basic sector, other basic sector employers together employ about 1.5 times the number of people working at Hanford.

A] though no major growth occurred in non-Hanford basic sector employment during FY 1988, which ended September 30, 1988, the fourth quarter of CY 1988 saw the opening of the expanded Columbia Center, the opening of Lamb-Weston's headquarters, and the opening of the coliseum. Construction activity at the coliseum and Columbia Center and increased income from tourism and retirees and higher agricultural product prices helped offset the loss of Hanford jobs. The following paragraphs summarize activity in the non-Hanford basic sector during CY 1988.

Washington Public Power Supply System. One major event during CY 1988 was the closure of the Supply System's Hanford Generating Plant, which depended on steam from the $N$ Reactor. Most of the personnel were reassigned. No significant activity is expected at the partially-completed WNP-I civilian power reactor during the next year. Supply System employment and payroll in 1988 were slightly less than the year before, with 1,600 workers and approximately $\$ 59$ million in payroll.

Agriculture and Agricultural Processing. One of the most significant events in agriculture during 1988 was that Lamb-Weston, Inc. announced that its corporate headquarters were being moved from Portland, Oregon to Kennewick, Washington. The new headquarters has added about 130 djget jobs in the Tri-Cities, about 50 of whom are transferred from Portland.

Seventy-eight are new local hires. Agricultural processing employment in September of 1988 was the same as in September 1987. (D) Farm income in 1988 will be higher than it has been for the past several years, likely exceeding $\$ 70 \mathrm{million}$. Prices for three of the main commodities grown in Benton and Franklin counties--wheat, potatoes, and apples--are all up from 20 to $30 \%$ relative to 1987. Based upon an estimate of value of production for major crops in the bi-county area, farm income in 1988 may be up from 20 to $25 \%$ over 1987. (C) Ideally, we would like to have a more direct source of farm profitability, but official farm income estimates at the local level are 1argely constructed from statewide data of doubtful validity for 1ocal analysis and are available only after a one- or two-year time lag.

0ther Major Employers. The performance of the non-Hanford manufacturing base and other major employers al so continues to be strong, with about 3,400 total employment. Together, Advanced Nuclear Fuels, Sandvik Special Metals,

(a) Personal communication with $\mathrm{Mr}$. Dick Williams, Lamb-Weston, Inc., October 25, 1988.

(b) Source: Washington State Department of Employment Security.

(c) See Appendix A, Section A.2. 
Boise Cascade's Wallula plant, Iowa Beef Processors (IBP) in Wallula, and regional railroad operations have added approximately 80 workers in the last year.

Regional Retailing. Construction of a 6,000-seat sport and special event coliseum near Columbia Center, the $\$ 15$ million addition to the Columbia Center, and the building up of surrounding businesses are all expected to increase the draw of the Tri-Cities as a regional retailing center. According to one source, the new Sears store at Columbia Center employs approximately 175 (75 new) local workers while the new Lamonts employs about 65 new workers. (a) The Costco and ShopKo discount chains have also moved into the area (the former is already operating while the latter began construction in November 1988). Besides Sears and Lamonts, 34 other new stores will be added to Columbia Center, with a total expected addition to local employment of 297. While some of this activity clearly represents a geographical shift of loca] activity (Sears, for example, closed its Pasco store), much is expected to be new, basic sector activity. (D) Another example of regional retailing is the Northwest Regional Autoplex, a Pasco automobile, light truck, and recreational vehicle retailing center. The autoplex consists of four dealerships comprising 13 franchises that advertise jointly throughout Centra] Washington and Northeast Oregon. The Autoplex dealers est imated sales of about $\$ 100$ to $\$ 110$ million during 1988 , up from about $\$ 93$ million in I9B7.

Tourism. Data from the Tri-Cities Visitor and Convention 8ureau indicates that the pace of tourist traffic to the Tri-Cities has increased during the last two years. (C) For calendar year 1986, the Visitor and Convention Bureau reports an estimated 402 conventions, tournaments, and tours in the Tri-Cities, involving about 60,100 visitors who spent an estimated $\$ 12.4 \mathrm{mil}$ lion in the local economy. In 1987, this increased to 694 conventions, tournaments, and tours with 56,500 visitors who spent an estimated $\$ 17.8$ million. In the first half of 1988,395 groups came to the Tri-Cities with 39,000 visitors and an estimated $\$ 12.1$ million expenditures, which represents another significant increase over the 262 groups, 20,600 visitors, and estimated $\$ 6.3$ million in expenditures in the first half of 1987 .

Retirement Community. Retirees are also increasing in number. of the 2,100 jobs lost at Hanford during FY 1988, about one-sixth to one-fifth appear to be retirees. For example, in the group of 607 departing individuals at Westinghouse Hanford Company who filled out the Hanford Worker Exit Survey (about $84 \%$ of those leaving), 108 (18\%) retired, and of these, 81

(a) Tri City Herald, September 23, 1988, p. 1.

(b) The DeBartolo Corporation, the mal1's developers and owners, forecast that sales at the mall will double with the new addition, from $\$ 100 \mathrm{mil}-$ lion per year to $\$ 200$ million per year. See "Expansion Keeps Mall Dominant," Tri-City Herald, October 5, 1988.

(c) All data reported in this paragraph came from a telephone contact with Mary Lindsay, Tri Cities Visitor and Convention Bureau, October 11, 1988. 
(75\%) stated that they would probably stay in the area. (a) Many of the lost job slots in the coming six months will also be retirees. Westinghouse Hanford Company Personnel Department staff estimate that approximateiy 300 of the 520 individuals who signed up for early retirement under a special incentive program announced in July 1988 are still on staff and are scheduled to Teave by the end of March 1989. Each of these voluntary retirees had three years of age and service added to their basis for calculated retirement benefits and were guaranteed a monthly payment of $\$ 250$ until eligible to draw Social Security old age benefits. The average cost of the early retirement package was approximately $\$ 1,000$ per montpper retiree (as opposed to about $\$ 700$ per month for the "normal" retiree). (b) Much of this retirement income can be expected to remain in the area.

A new retirement center with 114 units opened in May 1988 in North Richland, adding significant additional space to a market with three existing centers. Occupancy of the new center is low, but growing steadily. The number of Socjal Security recipients in Benton and Franklin Counties grew at an average annual rafe of $3.5 \%$ per year between 1980 and 1987 and numbered about 17,700 in $1987 .($ ) This was $27 \%$ more than in 1980 and $46 \%$ more than in 1975 .

\subsection{STATE AND LOCAL EMPLOYMENT AND INCOME}

Table 2.4 depicts state and county employment and earnings for the last two calendar years and the first nine months of 1988. (Data were not all available for all of the fourth quarter at the time this report was prepared.) The most striking fact that shows up in the table is that the Benton and Franklin County economies appear to have shrunk by about 2.5 to $3.7 \%$ during the last year while the state economy has grown by $1.5 \%$ (as measured by earnings) or $4.4 \%$, as measured by employment.

Thus, while the shrinkage of the Tri-Cities' economy was not as severe as expected by many analysts, given the number of lost jobs at Hanford, it still stands in marked contrast to the much stronger performance of the state

(a) The strictly voluntary Hanford Worker Exit Survey was given to departing Hanford workers during the spring and sumer of 1988 . Methods for administering the survey and dates during which the survey was used varied by contractor. A total of 774 questionnaires were returned. Only at Westinghouse Hanford Company was there a sufficiently comprehensive and known response rate to make the results representative of the population of departing workers. See Appendix B for further discussion of the Exit Survey and the suggested revisions to it.

(b) Personal contacts with Mr. Al Hawkins, Westinghouse Hanford Human Resources Department, Personnel and Reassignment Services and Mr. Gary Clogston, Westinghouse Company Human Resources Department, Compensation and Benefits, October 18, 198B. Cost data from Mr. Glen Belew, Westinghouse Human Resources Department, November 17, 1988.

(c) Persona] contact with Mr. P. R. Lerner, Social Security Administration, Baltimore, Maryland, October 6, 1988. Data were not avaj1able for 1988 when this report was prepared. 
IABLE 2.4. State and County Employment and Real Earnjngs, 1986, 1987 and Average for the First Nine Months of 1988 (a)

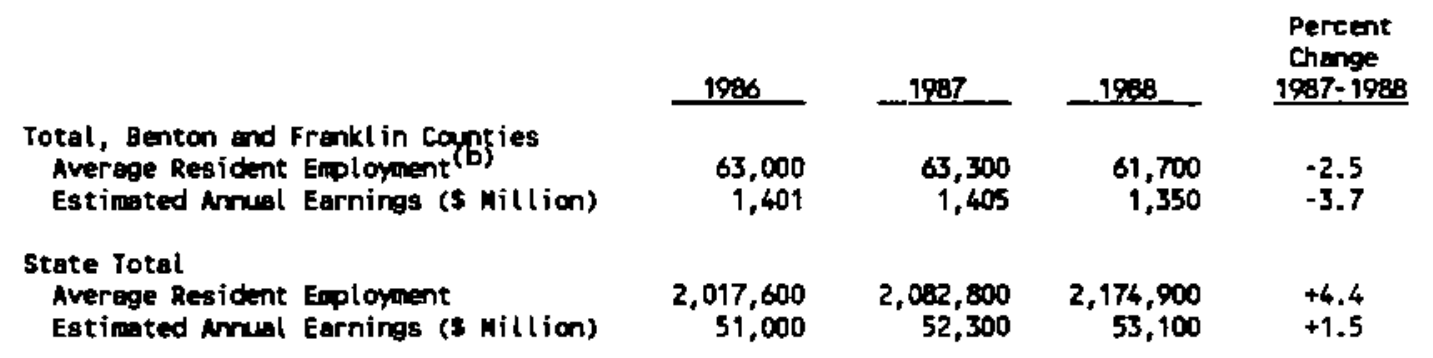

(a) All earnings figures in constent 1988 dollars.

(b) Partibl datb for 1988 is seasmally adjusted.

Sources: Date from DCE Richland Operations and Hanford Contractors, Haghinaton State Labor

Area Suluries (1986, 1987, 1988), Ueshington Labor Morket (1986, 1987, 1983),

U.S. Departient of Conerce, Bureau of Econmic Analysis, and Laghington State

Deportwent of Reverive (1988), scott et al. (1987).

as a whole. The other fact that is implicit in the table is that although the Tri-Cities' non-Hanford basic sector grew between 1986 and 1988, it has not made up for the loss in jobs and income at Hanford.

\subsubsection{Quarterly Employment by Sector}

Table 2.5 summarizes the changes in employment in the Tri-Cities that have occurred since the third quarter of 1987. As mentioned in Section 1 , all numbers in the tables represent quarterly average seasonally adjusted figures. The third quarter of 1987 is used as a reference period since it represents the quarter prior to the first round of layoffs at Hanford.

From the bottom the cumulative decline in the published resident employment was 2,250 from the third quarter of 1987 to the fourth quarter of 1988 . Hanford employment was down about 2,200 jobs over this time frame.

IABLE 2.5. Total Resident Employment, Tri-Cities Area, Recent History

\begin{tabular}{|c|c|c|c|c|c|c|}
\hline \multirow{2}{*}{ Employment Indicetor } & \multicolumn{6}{|c|}{ Quarter Ended } \\
\hline & $\begin{array}{l}\text { Sept. 30, } \\
1987 \\
\end{array}$ & $\begin{array}{l}\text { Dec. 31. } \\
1987 \\
\end{array}$ & $\begin{array}{l}\text { March 31, } \\
1968 \\
\end{array}$ & $\begin{array}{l}\text { June } 30 \\
1988 \\
\end{array}$ & $\begin{array}{l}\text { Sept. } 30, \\
1988 \\
\end{array}$ & $\begin{array}{l}\text { Dec. } 31 . \\
1988 \\
\end{array}$ \\
\hline $\begin{array}{l}\text { Quarterly Average Resident Enploniment } \\
\text { Hanford End-of-Cuarter Enploment }\end{array}$ & 14,500 & 14,100 & 13,500 & 12,900 & 12,400 & 12,200 \\
\hline $\begin{array}{l}\text { Henford Average Quarterly Resident Enployent } \\
\text { Nan-Henford Bas ic Sector }\end{array}$ & $\begin{array}{l}13,450 \\
17,950 \\
\end{array}$ & $\begin{array}{l}13,150 \\
18,000\end{array}$ & $\begin{array}{l}12,800 \\
18,100 \\
\end{array}$ & $\begin{array}{l}12,100 \\
18,100 \\
\end{array}$ & $\begin{array}{l}11,550 \\
18,100 \\
\end{array}$ & $\begin{array}{l}11,250 \\
18.400 \\
\end{array}$ \\
\hline Subtotal, Resident Basic & 31,400 & 31,450 & 30,900 & 30,200 & 29,650 & 29,650 \\
\hline Service Industries (Secondary) & 31.800 & 32,000 & 31.850 & 31.200 & 31,300 & 31,300 \\
\hline Total Resident Enployment & 63,200 & 63,150 & 62,750 & 61,400 & 60,950 & 60,950 \\
\hline $\begin{array}{l}\text { Cumulative Net Chenge } \\
\text { Henford And Procurenemts } \\
\text { other Basic } \\
\text { Service Sector (Secondary) }\end{array}$ & $\begin{array}{l}0 \\
0 \\
0 \\
\end{array}$ & $\begin{array}{r}-300 \\
50 \\
200 \\
\end{array}$ & $\begin{array}{r}-650 \\
150 \\
50 \\
\end{array}$ & $\begin{array}{r}-1,350 \\
150 \\
-600 \\
\end{array}$ & $\begin{array}{r}-1,900 \\
150 \\
-500 \\
\end{array}$ & $\begin{array}{r}-2,200 \\
450 \\
-500 \\
\end{array}$ \\
\hline Total & 0 & -50 & -450 & $-1,800$ & $-2,250$ & $-2,250$ \\
\hline
\end{tabular}


Employment in the non-Hanford basic sector was estimated to have increased by 450 jobs between the third quarter of 1987 and the fourth quarter of 1988 . The components of this increase can be roughly estimated and include the increase in local convention business that is estimated to have added about 100 jobs in the basic sector; and addition of about 200 jobs at Columbia Center that are assumed to be supported by sales to nonresidents.

As shown in the table, service sector (secondary) employment takes a sharp plunge in the second quarter of 1988 and basicaily remains flat for the rest of the year. In the fourth quarter of 1988, secondary employment is about 500 lower than the reference period of the third quarter of 1987 . Before too much is made of the quarter-to-quarter movements in secondary employment, some discussion of its estimation may be warranted. Secondary employment is estimated as a residual. That is, total basic employment is subtracted from total employment to yield an estimate of secondary employment. Although this procedure provides the most consistent picture of overall employment changes over long periods of time, it can display some weaknesses in a quarteriy framework shown here. Any errors in overall employment or basic sector employment, together with the seasonal adjustment procedures, are reflected in the secondary sector estimates.(a) Thus, our judgment is that the drop in the second quarter is spurious. The deciline of 500 by the fourth quarter is roughiy consistent with other employment information by industry (See Appendix A, Section A.3).

\subsubsection{Analysis of Recent Employment Changes}

In light of PNL's $N$ Reactor Closure Study released in the summer of 1987, a question that is being increasingly asked is why hasn't there been more of an impact on the rest of economy from the Hanford cutbacks? Many readers of that study may recall that a major finding of that study was that about 1.2 other jobs would be lost in the Tri-Cities for every job lost at Hanford. From the 2,200 jobs lost at Hanford thus far, one interpretation of the previous study is that we should have seen a decline in service sector employment of 2,650. Instead, the published employment figures indicate that only several hundred jobs have been lost outside of Hanford.

Several issues must be addressed to try to resolve this apparent inconsistency. The first issue relates to the time phasing of the response of jobs in the secondary sector to changes in the basic sector. As is sometimes overlooked in the 1987 study, the full impact of any Hanford cutbacks was expected to take several years or longer to be fully realized. A second issue involves the behavior of segments of the economy outside of Hanford.

(a) Unfortunately, local economic statistics cannot directly provide a detailed breakdown of the other basic and secondary sectors. The general approach is to estimate the secondary sector as a residual; that is secondary employment is calculated as total employment less Hanford less other basic employment. 
As Table 2.5 shows, the non-Hanford basic sector is estimated to have grown by 450 jobs between the third quarter of 1987 and the fourth quarter of 1988 . As intimated in section 2.3, increases in farm income, growth in the general retirement population, and early retirement programs for Hanford workers also all helped to maintain overall spending in the Tri-Cities during 1988.

With these issues in mind, a natural question is how can we explain the events of 1988. By using the time-phased multipliers and estimates of the components of the basic sector, the employment projection model was used to take an historical look at the period from the third quarter of 1987 through the fourth quarter of 1988 .

Although this procedure is explained in detail in Appendix $A$, the major results can be easily summarized. Using time-phased multipliers and the assumption of no change in the remainder of non-Hanford basic sector, one could have expected a reduction of about 1,000 workers in the secondary sector by the end of 1988 . Actual job losses were in the neighborhood of 500 . Thus, the effects of the non-Hanford basic sector offset about an equal number of jobs or about 500 .

\subsection{POPULATION AND HOUSING}

Most population indicators for the Tri-Cities area show that the resident population declined slightly in 1987 and early 1988, although area population may still be above its 1986 level. There are several such indicators, including the state's annual April l estimate of local population, the number of residential telephone customers, observed house and apartment vacancy rates, the school district enrollment, and others. Table 2.6 shows the resident population estimated by the state's Office of Financial Management as of Apri] 1 for the past three years. The table indicates that the immediate Tri-Cities area lost about 425 persons between Apri1 1, 1987 and Apri1 1, 1988 , although population in Benton and Frankl in counties was constant. The bi-county area grew slightly in population over the two-year period.

Calculations based on more recent telephone customer data in Table 2.7 indicate that the local population downturn that began late in 1987 probably has continued, though not at as fast a pace as employment has declined at Hanford. The table produces a very rough estimate, in part because residential telephone customers do not bear a one-to-one correspondence to the number of households within a service area, and also because the boundaries of telephone service areas do not match the boundaries of their corresponding cities. As long as the losses in telephone customers and population are similarly distributed, however, the telephone customer data should provide a good indication of population outmigration. There has been little measurable effect to date, however, on the school districts or on the retajl sector.

Table 2.8 shows that total school district enrollments in the Tri-Cities have generally decreased only slightly between 1987 and 1988 . Enrollment is down in Richland, but up in Pasco and Kennewick. Much of the increase, however, can be attributed to the influx of kindergartners into the schools. The cohort of students in grades K-1l during the 1987 school year in the 
IABLE 2.6. Benton and Frankl in County Resident Population, 1986 Through 1988

\begin{tabular}{l} 
Jurisdiction \\
\hline Richland \\
Kennewick \\
Pasco \\
Subtotal \\
West Richland \\
Benton City \\
Prosser \\
Total, Tri-Cities Area \\
Other-Benton or \\
Franklin Counties \\
Total
\end{tabular}

\begin{tabular}{|c|c|c|c|}
\hline$\frac{\text { April }}{1986}$ & $\begin{array}{l}\text { esident F } \\
1987\end{array}$ & $\begin{array}{l}\text { lation } \\
1988 \\
\end{array}$ & $\begin{array}{c}\text { Change } \\
1987-198 \\
\end{array}$ \\
\hline $\begin{array}{l}30,240 \\
36,600 \\
18,420\end{array}$ & $\begin{array}{l}30,280 \\
37,320 \\
18,520\end{array}$ & $\begin{array}{l}30,140 \\
37,180 \\
18,430\end{array}$ & $\begin{array}{l}-0.5 \\
-0.4 \\
-0.5 \\
\end{array}$ \\
\hline 85,260 & 86,120 & 85,750 & -0.4 \\
\hline $\begin{array}{l}3,720 \\
1,820 \\
4,010 \\
\end{array}$ & $\begin{array}{l}3,700 \\
1,815 \\
4,000 \\
\end{array}$ & $\begin{array}{l}3,670 \\
1,800 \\
3,990 \\
\end{array}$ & $\begin{array}{r}-0.8 \\
-0.8 \\
-0.2 \\
\end{array}$ \\
\hline 94,810 & 95,635 & 95,210 & -0.4 \\
\hline 44,490 & 43,965 & 44,390 & +1.0 \\
\hline 139,300 & 139,600 & 139,600 & 0.0 \\
\hline
\end{tabular}

Sources: State of Washington Office of Financial Management.

IABLE 2.7. Population Changes, 1987 to September 1988, Based on Residential Telephone Customers

\begin{tabular}{|c|c|c|c|c|c|}
\hline City & $\begin{array}{l}1987 \\
\text { Residential } \\
\text { Customers } \\
\end{array}$ & $\begin{array}{c}1987 \\
\text { April } 1 \\
\text { Population } \\
\end{array}$ & $\begin{array}{l}\text { Population } \\
\text { Per Customer }\end{array}$ & $\begin{array}{c}1987 \text { to } \\
\text { September } \\
1988 \\
\text { Change in } \\
\text { Customers } \\
\end{array}$ & $\begin{array}{l}\text { Estimated } \\
\text { Change in } \\
\text { Population }\end{array}$ \\
\hline $\begin{array}{l}\text { Richland } \\
\text { Kennewick } \\
\text { Pasco }\end{array}$ & $\begin{array}{r}13,210 \\
19,700 \\
9,610 \\
\end{array}$ & $\begin{array}{l}30,280 \\
37,320 \\
18,520 \\
\end{array}$ & $\begin{array}{r}2.2 \\
1.89 \\
1.93 \\
\end{array}$ & $\begin{array}{r}-326 \\
-128 \\
-69 \\
\end{array}$ & $\begin{array}{l}-746 \\
-241 \\
-133 \\
\end{array}$ \\
\hline Subtotal & 42,520 & 86,120 & -- & -523 & $-1,120$ \\
\hline $\begin{array}{l}\text { West Richland } \\
\text { Benton City }\end{array}$ & $\begin{array}{l}1,780 \\
1,457\end{array}$ & $\begin{array}{l}3,700 \\
1,815\end{array}$ & $\begin{array}{l}2.08 \\
1.25\end{array}$ & $\begin{array}{l}-21 \\
-14\end{array}$ & $\begin{array}{l}-44 \\
-18\end{array}$ \\
\hline $\begin{array}{l}\text { Local Service } \\
\text { Area }\end{array}$ & 45,757 & 91,635 & -- & -558 & $-1,182$ \\
\hline
\end{tabular}

Sources: Estimated from data supplied by the Washington State Office of Financial Management, General Telephone and Electric, and Pacific Northwest Bell. 
IABLE 2.8. School District Enrollments, 1987 and 1988 School Years

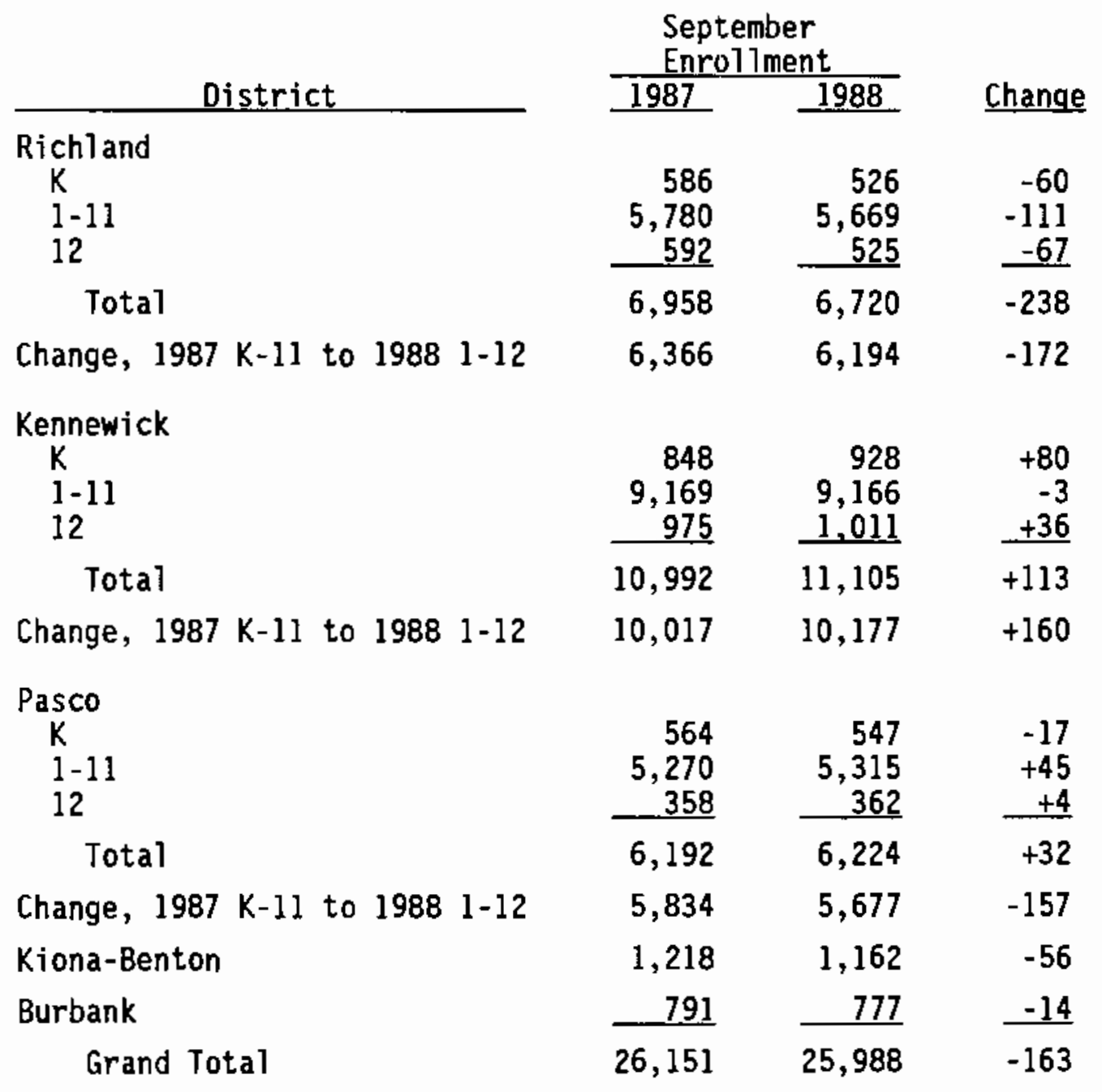

Source: Data supplied by individual districts. 
three core disfrjcts (Richland, Kennewick, and Pasco) declined by 169 students by 1988 . (a) The individual changes were -172 in Richland, +160 in Kennewick, and -157 in Pasco. However, the kindergarten increases in Kennewick and the apparent improved retention of seniors in Kennewick and Pasco (grade 12 population increased) offset this loss to some degree, resulting in a net loss of only 93 students in the three districts. Enrollment fell in Kiona-Benton and Burbank districts, adding to a total net loss in September enrollment of 163.

Figure 2.1 indicates average selling prices for single-family homes recorded by the Multiple Listing Service (MLS) and the Tri-City Board of Realtors have continued to fall during 1988 from their 1981 peak, declining about $2.5 \%$ for the year. However, monthly average selling price data from the Board of Realtors prices have been increasing since April 1988. Simi1 arly, indications from a recent report by the local real estate appraisal community, based on comparable arms-length sales of single-family houses, are that prices declined at about $0.5 \%$ per month, or $6 \%$ per year, through the first half of the year. Thereafter, low inventories of units caused prices to stabilize. A significant number of houses on the market (about onefourth) are for sale "for debt only," or are being offered by financial

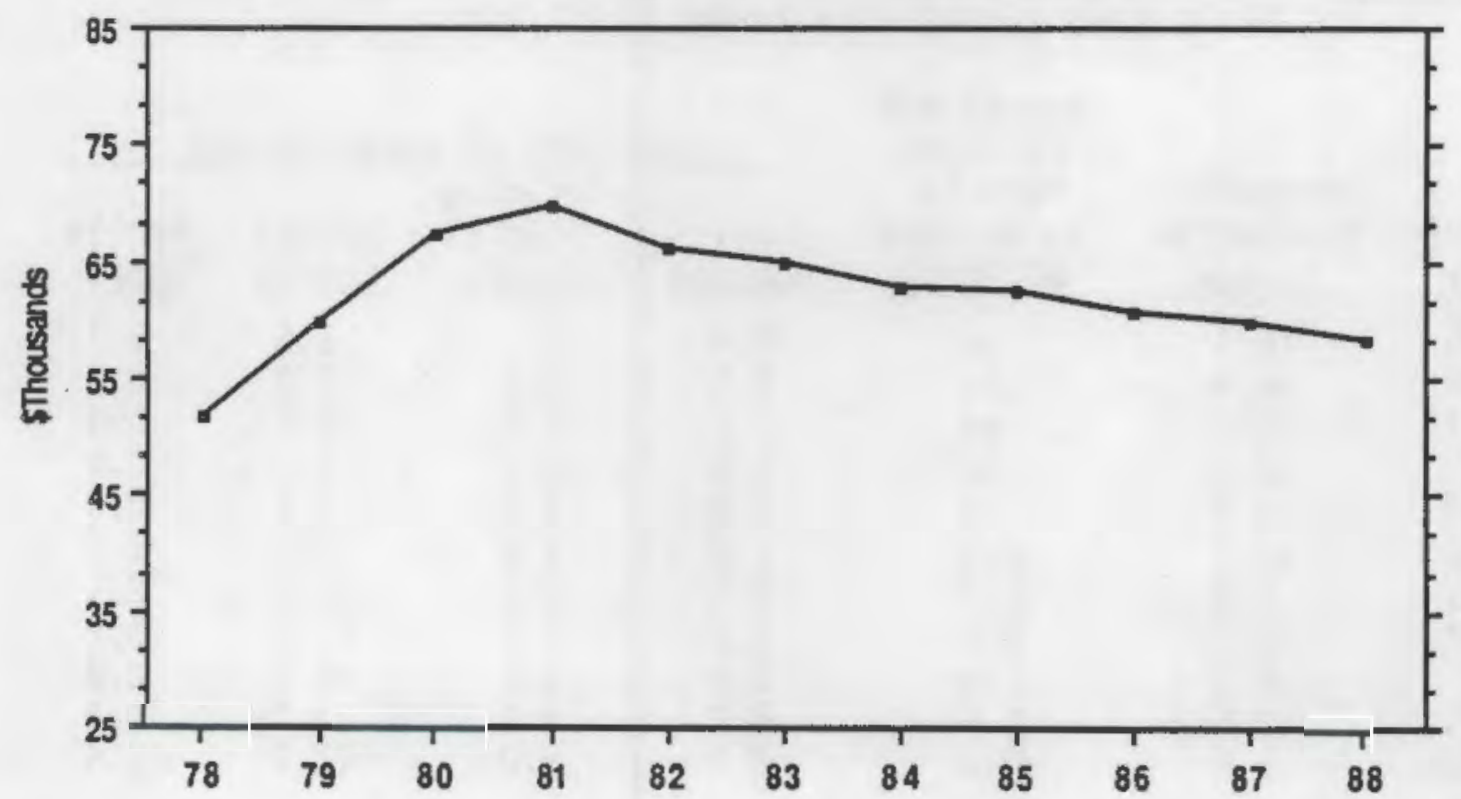

FIGURE 2.1. Index of Selling Price for Single Family Houses in Tri-Cities Real Estate Market, 1977-1988

(a) The $1987 \mathrm{~K}-11$ cohort represents those students who would ordinarily be in grades 1-12 in 1988. Net loss in this cohort represents both net outmigration of school-age children and dropouts. 
institutions and relocation companies. (a) These are, in effect, distress offerings and may indicate additional market softness.

Table 2.9 shows that the Tri-Cities housing market may not yet have adjusted to the steady population declines that have occurred in the area since 1981, even though building permits data indicate very small additions to the stock. The last three housing vacancy surveys (April 1983, October 1985, June 1988) show that in the post-WPPSS era, the vacancy rate has persisted at above $8 \%$, and that vacancy rates for single family housing and mobile homes have continued to increase. Multifamily housing units (apartments) vacancy rates may have stabilized, but it is difficult to tell because the last three surveys were all taken at different times of the year.

Table 2.10 shows historical information on population changes, interest rates, sales volume, housing prices, and turnover in Tri-Cities housing stock (number of days on market). In the late 1970s, because mortgage interest rates lagged behind inflation, effective mortgage interest rates were actually negative. This was accompanied by rapid population growth. Under these

TABLE 2.9. Population Change, Building Permits, and Vacancy Rates in Tri-Cities Real Estate Market, 1975-1988

\begin{tabular}{|c|c|c|c|c|c|c|}
\hline \multirow[b]{2}{*}{$\begin{array}{l}\text { Date of } \\
\text { Survey }\end{array}$} & \multirow[b]{2}{*}{$\begin{array}{l}\text { Percent } \\
\text { Population } \\
\text { Change } \\
\end{array}$} & $\begin{array}{c}\text { Annual New } \\
\text { Building }\end{array}$ & \multicolumn{4}{|c|}{ Percent of Units Vacant } \\
\hline & & $\begin{array}{l}\text { Permits } \\
\text { as Percent } \\
\text { of Stock }\end{array}$ & $\begin{array}{c}\text { All } \\
\text { Housing }\end{array}$ & $\begin{array}{l}\text { Detachec } \\
\text { Single } \\
\text { Family } \\
\end{array}$ & $\begin{array}{l}\text { Multi- } \\
\text { Family } \\
\end{array}$ & $\begin{array}{l}\text { Mobile } \\
\text { Homes }\end{array}$ \\
\hline ay 75 & +8.4 & na & 0.6 & 0.5 & 1.6 & 0.7 \\
\hline ay 76 & +6.4 & na & 0.8 & 0.6 & 1.8 & 0.6 \\
\hline Nov 77 & +8.0 & na & 1.7 & 0.9 & 4.1 & 0.9 \\
\hline Dec 78 & +8.1 & na & 1.3 & 0.9 & 2.7 & 0.6 \\
\hline Oct 79 & +5.6 & na & 2.0 & 1.2 & 4.4 & 0.9 \\
\hline Apr 80 & +3.9 & 0.9 & 2.8 & 1.2 & 7.0 & 1.6 \\
\hline Apr 81 & -1.5 & 1.0 & 4.3 & 1.5 & 11.4 & 2.1 \\
\hline Apr 82 & -2.2 & 0.6 & 5.1 & 2.5 & 12.1 & 3.2 \\
\hline 83 & -0.5 & 0.6 & 8.6 & 3.6 & 19.1 & 8.8 \\
\hline 85 & -2.6 & 0.5 & 8.2 & 4. & 17.7 & 10.4 \\
\hline Jun 88 & -0.9 & 0.2 & 8.9 & 5.0 & 17.7 & 11.4 \\
\hline
\end{tabular}

Sources: Tri-Cities, Washington Housing Vacancy Survey, June 1988, Federal Home Loan Bank of Seattle, June 1988. Building permits collected from permit-issuing jurisdictions. Estimated stock from Washington State office of Financial Management.

(a) Classification of Richland and Kennewick houses listed for sale through the Multiple Listing Service as of October 7, 1988 supplied by Henderson, Vining, and Associates, Kennewick, Washington. 
TABLE 2.10. Tri-Cities Population Change, Mortgage Interest Rates, Sales Volume and Average Selling Prices of Housing Units in the Tri-Cities Real Estate Market, by Calendar Year, 1978-1988

\begin{tabular}{|c|c|c|c|c|c|c|c|c|}
\hline \multirow[b]{2}{*}{ Date } & \multirow{2}{*}{$\begin{array}{l}\text { Percent } \\
\text { Populatigen } \\
\text { Change (b) } \\
\end{array}$} & \multirow{2}{*}{$\begin{array}{c}\begin{array}{c}\text { Existing Home } \\
\text { Mortgage Interest } \\
\text { Rate } \\
(c)\end{array} \\
\end{array}$} & \multirow{2}{*}{$\begin{array}{c}\text { Sales } \\
\text { Volume, Single- } \\
\text { Family Houses } \\
\text { (Units Sold } \\
\text { During Year) } \\
\end{array}$} & \multicolumn{3}{|c|}{$\begin{array}{l}\text { Average Price Detached } \\
\text { Single-family House }\end{array}$} & \multirow{2}{*}{$\begin{array}{c}\text { Percent } \\
\text { Change, } \\
1988 \\
\text { Dollars } \\
\end{array}$} & \multirow{2}{*}{$\begin{array}{l}\text { Average } \\
\text { Days on } \\
\text { Market (a) }\end{array}$} \\
\hline & & & & $\begin{array}{l}\text { As } \\
\text { Reported }\end{array}$ & $\begin{array}{c}1988 \\
\text { Dollars }\end{array}$ & $\begin{array}{l}\text { Percent } \\
\text { Change }\end{array}$ & & \\
\hline 1978 & +8.0 & 9.40 & 2,356 & $\$ 51.7$ & 593.7 & NA & NA & NA \\
\hline & & & & & & & & MA \\
\hline 198 & +5.6 & 12. & & 67.3 & 96. & 12.4 & -1.0 & NA \\
\hline 198 & +3.9 & 14. & 1,082 & 69.7 & 90.6 & 3.6 & -6.1 & 129 \\
\hline & -1.5 & & & 66. & & -5.3 & -10.8 & 82 \\
\hline & -2.2 & 12. & 1,0 & 64 & $\pi 7$ & -1.7 & -4.7 & 105 \\
\hline & -0.5 & 12.00 & 1,070 & 62. & 71. & -3.4 & -7.4 & 99 \\
\hline & -2.2 & 11.18 & 985 & 62. & 68 & -0.3 & -3. & 85 \\
\hline & -1.1 & & 1,266 & 60.7 & 65. & -2.9 & -4.7 & 91 \\
\hline & +0.2 & 8. & 1,168 & & 62. & -1.7 & -5.1 & 95 \\
\hline 19 & 0.0 & 9.11 & 1,262 & $58.2^{(d)}$ & 58.2 & -2.5 & -6.3 & 89 \\
\hline
\end{tabular}

(a) Tri-Cities Real Estate Research Report and Tri-City Board of Realtors.

(b) Mashington State Office of Financial Managenent. Change in MSA population from April 1 of year listed from April 1 of the preceding year. Local city population is doun slightly since July 1987.

(c) Rates from Survey of Current Business, Novenber 1988, p. S-6, Business Statistics 1986, P. 65, and Monthly Labor Review, May 1988, P. 95 and December 1987, p. 87.

(d) Includes several repossession sales, which lowered the average sel ling price during the year. This was a result of a once-only "achievement recognition" program anong local real tors.

circumstances, it is not surprising that it was possible for potential buyers to bid up the real price of housing, a situation that existed in the rest of the nation as well as in the Tri-Cities. The peak nominal price was reached in 1981 although the peak real value was reached somewhat earlier. Mortgage interest rates increased significantly in the early 1980 s and population growth turned negative in the Tri-Cities in 1981-1982. This had two effects. In the first place, the real price of housing in the Tri-Cities fell sharply. In the second place, the average time required to sell a house probably increased, and sales volume temporarily collapsed. Since their peak about 1983, however, mortgage interest rates have been slowly declining. This has been matched by a slow decrease in the rate at which real (inflation-adjusted) housing prices have fallen in the face of falling local population. Fluctuations in the interest rate appear to be matched by fluctuations in average selling price, time on market, or both. Thus, declining interest rates may have tended to reduce the buyer cost associated with a given-sized mortgage and may have held a floor under local housing market prices. Any substantial future increases in interest rates can be expected to negatively affect price, as will any future population declines.

Building activity in Benton County and the City of Pasco has been highly correlated with the trends in selling prices, units sold, interest rates, and population changes reported in Tables 2.9 and 2.10 . Changes in building activity, in fact, appear to have behaved as a "leading indicator," probably reflecting rising inventories and vacancies and anticipating by one or more years the declines in nominal housing prices, as demonstrated in Table 2.11. Thus, during the late 1970 s when effective interest rates were at extremely 
TABLE 2.11. Tri-Cities New Residential Construction, by Calendar Year, 1978 to 1988

\begin{tabular}{|c|c|c|c|c|c|c|c|c|c|c|c|}
\hline \multirow[b]{2}{*}{ Year } & \multicolumn{5}{|c|}{ Benton County Building Permits } & \multicolumn{5}{|c|}{ Pasco Building Permits } & \multirow[b]{2}{*}{$\begin{array}{l}\text { Grand } \\
\text { Total } \\
\end{array}$} \\
\hline & $\begin{array}{l}\text { Single } \\
\text { Family } \\
\end{array}$ & Duplex & $\begin{array}{l}\text { Multi- } \\
\text { Family }\end{array}$ & $\begin{array}{l}\text { Mobile } \\
\text { Home }\end{array}$ & Total & $\begin{array}{l}\text { Single } \\
\text { fanily }\end{array}$ & Duplex & $\begin{array}{l}\text { Multi- } \\
\text { Family }\end{array}$ & $\begin{array}{l}\text { Mobile } \\
\text { Home }\end{array}$ & Total & \\
\hline 1978 & 743 & 106 & $\cdots$ & 213 & 1,062 & 36 & 6 & 56 & 27 & 125 & 1,187 \\
\hline 197 & 309 & 102 & $\because$ & 294 & 705 & 80 & $\cdots$ & 448 & 34 & & 1,267 \\
\hline 1980 & 115 & 14 & 14 & 198 & 339 & 43 & 24 & 46 & 20 & 133 & 472 \\
\hline 1981 & 108 & 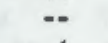 & $\cdots$ & 279 & 387 & 38 & 26 & 19 & 28 & 111 & 49 \\
\hline 1982 & 61 & 4 & $\cdots$ & 183 & 248 & 21 & 6 & - & 16 & 43 & 29 \\
\hline 1983 & 68 & $\cdots$ & 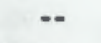 & 192 & 260 & 17 & - & $\cdots$ & 12 & 29 & 28 \\
\hline 1984 & 51 & -- & $\cdots$ & 189 & 240 & 5 & $\cdots$ & $\cdots$ & 9 & 14 & 25 \\
\hline 1985 & 39 & 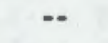 & $\cdots$ & 175 & 214 & 3 & $\cdots$ & $\cdots$ & 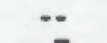 & 3 & 21 \\
\hline 1986 & 34 & $\cdots$ & $\cdots$ & 170 & 204 & 6 & - & $\cdots$ & 7 & 13 & 21 \\
\hline 198 & 32 & $-\cdot$ & $\cdots$ & 139 & 171 & 4 & - & $\cdots$ & 6 & 10 & 18 \\
\hline $1988^{(a)}$ & 16 & -. & -. & 77 & 93 & 2 & .. & - & .. & 2 & \\
\hline
\end{tabular}

(a) Figures for 1988 reflect activity for January 1988 through August 1988 only.

Sources: Benton County Building Department; Building Inspector's Office, Pasco, Uashington.

low or even negative levels, population growth was strong and average prices of single family homes were high and growing in both real and nominal terms, the construction of single family homes began to fall precipitously. For example, in 1979 the number of building permits for single family homes fell sharply (by 390 units) from the previous year's value of 779 even though annual population growth was at its peak value and real prices had not reached their peak value. Whether housing starts serve as an effective leading indicator of positive changes in the housing market of the Tri-Cities area is an open and unanswered question. It is noteworthy that downward trends in building activity for all types of dwellings in the Tri-Cities market have continued through the first 8 months of 1988 . Real estate agents and appraisers report very low inventories of houses for sale in the last part of 1988. This may encourage building in 1989.

\subsection{TRADE AND UTILITIES}

Changes in the economic health and population in the Tri-Cities can also be measured by the level of retail sales and number of utility customers. Both are imperfect indicators. Retail sales data, for example, do not correlate perfectly with local personal income because of changes in the personal savings rate, changes in the amount of out-of-town purchases, and changes in the number and spending habits of out-of-town customers coming to the Tri-Cities.

Sales tax data also provide an uncertain picture of consumer purchases because many "retail" sales, including several large sales, are sales involving industrial equipment or construction projects. In Richland, for example,

(a) To the extent that Oregon shoppers make use of their tax cards (which exempt Oregon residents from Washington sales tax), their purchases in the Tri-Cities will not show up in taxable retail sales figures. Sales will less closely correlate with local incone. 
the largest "retail" sales in 1987 and 1988 have been posted by WPPSS, General Telephone, Advanced Nuclear Fuels, and several construction firms. Moreover, two key components of consumer spending--food and most personal services--are not subject to the retail sales tax. Growth in the export component of retail sales would tend to mask any downturn in local purchasing.

Changes in the number of residential telephones appear to correlate well with estimates of population change in most localities. However, increases in the number of multiple lines to single residences (the so-called "teenager effect") could again mask small changes in population.

Figure 2.2 shows indicators of regional business activity (taxable retail sales) and population (residential telephone customers). Both sources show relatively constant business activity and population over the three years ending in 1987. However, preliminary data through September 1988 indicate that 1988 local population and business activity may be down slightly since 1987.

\subsection{TAX BASE OF STATE AND LOCAL GOVERNMENT}

While not all local government jurisdictions are equally dependent upon sales and use taxes and property taxes to fund their services and programs, these taxes provide a large portion of the financial base of every local government in Benton and Franklin Counties. In addition, growth or decline

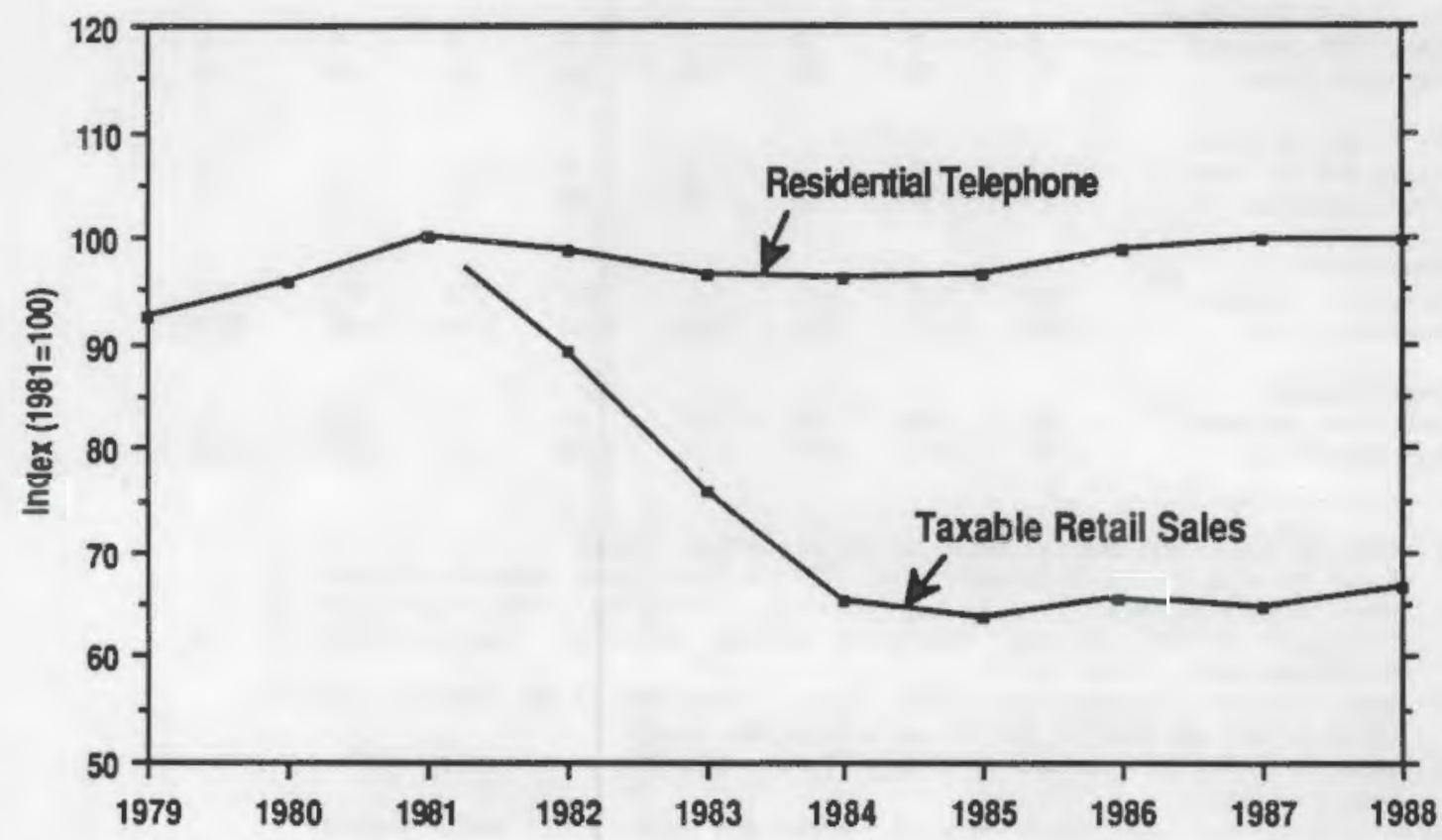

FIGURE 2.2. Indexes of Tri-Cities Area Taxable Retail Sales and Residential Telephone Utility Customers by Calendar Year, 1979-1988 
in the tax bases for these taxes provide yet another indicator of the current level of economic activity (sales and use tax base) and an indicator of property values (assessed valuation).

Table 2.12 shows the historical year-to-year changes in the major tax bases of the principal local governments in Benton and Franklin Counties. As can be seen by the table, Kennewick, Richland, and Pasco all experienced increases in their sales and use tax bases since 1981, while their property tax bases declined. Benton County, Benton City, and West Richland have had steep declines in their sales and use tax bases since 1981 and Benton County's assessed value has also declined. While Kennewick suffered from the post-WPPSS decline in business sales and property values, its tax base

TABLE 2.12. Sales, Use, and Property Tax Base by Jurisdiction and Calendar Year, Tri-Cities Area, 1981-1988 (\$ Million)

\begin{tabular}{|c|c|c|c|c|c|c|c|c|}
\hline Jurisdiction & 1981 & 1982 & $\underline{1983}$ & 1984 & 1985 & 1986 & $\underline{1987}$ & 1988 (a) \\
\hline $\begin{array}{l}\text { City of Richland } \\
\text { Sales and Use Base } \\
\text { Assessed Value }\end{array}$ & $\begin{array}{r}\$ 189 \\
1102\end{array}$ & $\begin{array}{l}\text { s } 201 \\
1117\end{array}$ & $\begin{array}{r}213 \\
1004\end{array}$ & $\begin{array}{l}5192 \\
933\end{array}$ & $\begin{array}{l}512 \\
921\end{array}$ & $\begin{array}{r}212 \\
926\end{array}$ & $\begin{array}{r}224 \\
915\end{array}$ & $\begin{array}{r}5214 \\
899\end{array}$ \\
\hline $\begin{array}{l}\text { City of Kennewick } \\
\text { Sales and Use Base } \\
\text { Assessed Yalue }\end{array}$ & $\begin{array}{l}325 \\
982\end{array}$ & $\begin{array}{r}339 \\
1034\end{array}$ & $\begin{array}{l}332 \\
935\end{array}$ & $\begin{array}{l}328 \\
910\end{array}$ & $\begin{array}{l}330 \\
862\end{array}$ & $\begin{array}{l}344 \\
864\end{array}$ & $\begin{array}{l}344 \\
887\end{array}$ & $\begin{array}{l}380 \\
877\end{array}$ \\
\hline $\begin{array}{l}\text { ty of Pasco } \\
\text { Sales and Use Base }\end{array}$ & $\begin{array}{l}234 \\
451\end{array}$ & $\begin{array}{l}253 \\
483\end{array}$ & $\begin{array}{l}258 \\
448\end{array}$ & $\begin{array}{l}256 \\
455\end{array}$ & $\begin{array}{l}240 \\
432\end{array}$ & $\begin{array}{l}261 \\
401\end{array}$ & $\begin{array}{l}264 \\
393\end{array}$ & $\begin{array}{l}270 \\
371\end{array}$ \\
\hline $\begin{array}{l}\text { ity of West Richland } \\
\text { Sales and Use Base } \\
\text { Assessed Value }\end{array}$ & $\begin{array}{l}6 \\
74\end{array}$ & $\begin{array}{l}7 \\
78\end{array}$ & 95 & $\begin{array}{l}6 \\
95\end{array}$ & $\begin{array}{r}5 \\
85\end{array}$ & $\begin{array}{r}6 \\
84\end{array}$ & $\begin{array}{r}5 \\
80\end{array}$ & $\frac{4}{79}$ \\
\hline $\begin{array}{l}\text { City of Benton Cit } \\
\text { Sales and Use Ba } \\
\text { Assessed Value }\end{array}$ & 28 & $\begin{array}{r}8 \\
29\end{array}$ & 36 & $\begin{array}{r}5 \\
35\end{array}$ & $\begin{array}{r}6 \\
32\end{array}$ & 31 & 25 & $\begin{array}{r}7 \\
22\end{array}$ \\
\hline $\begin{array}{l}\text { Benton County } \\
\text { Sales and Use Base }{ }^{(b)} \\
\text { Assessed Value }\end{array}$ & $\begin{array}{r}737 \\
3262\end{array}$ & $\begin{array}{r}550 \\
3479\end{array}$ & $\begin{array}{r}418 \\
3264\end{array}$ & $\begin{array}{r}245 \\
3156\end{array}$ & $\begin{array}{r}242 \\
3025\end{array}$ & $\begin{array}{r}246 \\
3000\end{array}$ & $\begin{array}{r}224 \\
2957\end{array}$ & $\begin{array}{r}230 \\
2870\end{array}$ \\
\hline $\begin{array}{l}\text { Frankl in County } \\
\text { Sales and Use Base }{ }^{(c)} \\
\text { Assessed Value }\end{array}$ & $\begin{array}{r}72 \\
1161\end{array}$ & $\begin{array}{r}80 \\
1235\end{array}$ & $\begin{array}{r}82 \\
1171\end{array}$ & $\begin{array}{r}93 \\
1176\end{array}$ & $\begin{array}{r}81 \\
1154\end{array}$ & $\begin{array}{r}78 \\
1118\end{array}$ & $\begin{array}{r}76 \\
1100\end{array}$ & $\begin{array}{r}81 \\
1083\end{array}$ \\
\hline
\end{tabular}

(a) Base for sales and use tax based on the percentage change in the base from first three quarters of calendar year 1987 to first three quarters of calendar year 1988 for Richland, Pasco, and Kennewick. Other estimates are based on the first half of 1987 and 1988 . Estimated assessed values for property tax are as of mid-November, 1988.

(b) Based on sales and use base in the unincorporated area of the county, plus $15 \%$ of sales and use base in the cities within the county.

(c) Based on sales and use base outside of Pasco, plus $15 \%$ of the sales and use base in Pasco.

Sources: Washington State Department of Revenue and Benton and Franklin County Assessors. Assessed value is the assessed value, net of open space and other exemptions, by the county assessor of all real and personal property within the jurisdiction for the general expense tax levy. 
stabilized and even increased in the last three years. This is at least partially due to growth in business volume and business property value in the immediate vicinity of the Columbia Center, (a) but may al so be partially the result of an aggressive annexation policy that has added population and residential areas formerly located in the unincorporated county. Richland and Pasco both have experienced some turnaround in business volume since 1985, but no increase in assessed property value. Almost all the remaining jurisdictions have shown some losses. Benton County (which depends for aimost a third of its use and sales tax revenue on direct Hanford contractor activity) and Benton City, in which a large number of Hanford or WPPSS workers Tive, have been particularly hard hit.

The estimated 1988 sales and use tax figures presented in the table are not final numbers, since they represent only results through the third quarter of calendar year 1988 for Richland, Pasco, and Kennewick (fourth quarter figures by jurisdiction were not available from the Washington State Department of Revenue). West Richland, Benton City, Benton County, and Franklin County jurisdiction estimates are based on first and second quarter figures, due to unavailability of data. While first and second quarter sales were up in most of the jurisdictions, the figures reveal that sales were down through the third quarter in Richland, while Kennewick and Pasco showed some increases through the third quarter.

The assessed values in the various jurisdictions in 1988 for the 1989 tax year also contain some significant uncertainties. For example, in the absence of any sales data for downtown Pasco property, the Franklin County Assessor's office based their assessed valuation on a downward market adjustment. Some limited sales information has become available since the valuation that suggest the market adjustment was too large and may have to be reversed for the 1990 tax year.

\subsection{PUBLIC SERVICE DEMANDS}

Public service demands have shown a mixed response to the changes in the local economy. It appears, for example, that local hospital admissions may be down more than would be predicted by the national declining trends in inpatient medical procedures, although it is difficult to attribute the change entirely to Hanford. Applications have increased at the local food banks, although they have not for state unemployment insurance.

Table 2.13 provides information on a number of indicators of social service demand in the Tri-Cities. The number of unemployment insurance

(a) For example, Columbia Center's retail sales increased from about $\$ 80$ million to $\$ 100$ million between 1987 and 1988 . The Columbia Center yielded $\$ 840,000$ in sales tax revenue and $\$ 65,000$ in property tax revenue during 1987. Property taxes are expected to increase by $\$ 44,000$ for 1989 with the new $\$ 15$ million addition. See "Miracle in the Desert," Tri-City Herald, October 5, 1988, p. B1. 
TABLE 2.13. Annua] Average Case Loads, Selected Social Service Functions in the Tri-Cities Area, by Calendar Year, 1984-1988

$\begin{array}{lrrrrrr}\text { Agency or Program_ } & \frac{1984}{\text { NA }} & \frac{1985}{\text { NA }} & \frac{1986}{N A} & \frac{1987}{2,755} & \frac{1988}{2,785} \\ \begin{array}{l}\text { Unemployment } \\ \text { Insuranfe Benefici- } \\ \text { aries (a) }\end{array} & & & & & & \\ \text { Food Stamp Recipients } & 2,746 & 3,088 & 3,566 & 3,882 & 4,238 \text { (b) } \\ \text { AFDC-R Caseload } & 1,428 & 1,756 & 3,082 & 2,239 & 2,249 \text { (b) } \\ \text { AFDC-E Caseload } & 132 & 247 & 350 & 389 & 354 \text { (b) }\end{array}$

(a) Benton and Franklin County data were not available prior to May 1986. Al1 12 months are included in 1988 figures.

(b) 1988 estimates are based on a comparison of the first 11 months with the first 11 months of 1987.

Sources: Washington State Departments of Employment Security and Social and Health Service.

claimants has not increased appreciably in 198B on a year-to-year basis, somewhat surprising in view of the number of Hanford job losses. It appears that those who left Hanford either have already left the area to take new jobs (which would be expected, given the high proportions of scientists and engineers thus far), have retired, or have simply not applied. This situation can be expected to change if large numbers of blue-collar Hanford workers and service sector workers begin to lose their jobs. Case loads for AFDC-R (regular program, Aid to Families with Dependent Children) and AFDC-E (AFDC program for families with at least one employable adult) have both remained constant, while food stamp recipients have been up in at least some recent months, possibly reflecting some increased economic distress. State Department of Social and Health Services staff speculate that one reason for the decline in AFDC- $R$ is the Immigration Reform Act (being a welfare recipient is a barrier to qualification).

The Tri-Cities food banks report that the number of people requiring assistance increased from 1986 to 1987 , from about 48,600 to nearly 50,000 . During 1988 their impression is that, while the number of customers served has not increased significantly, many of the customers require more frequent help. This has been a result of many of these people working on an on-call or part-time basis, making them periodically ineligible for government programs while still in need of assistance.

A brief telephone survey of local social service agencies was conducted by staff of the Governor's Office in October and November, 1988, and yielded the following additional information concerning local social service 
demands. (a) Child Protective Services in Pasco noted an increase of complaints and families in conflict figures (2721 for 1988 , versus 2001 in 1987), as well as an increase in the severity of cases and a loss of foster homes. Carondelet Psychiatric Care Center, which performs mainly long term mental health care, has seen little change in activity, but Lutheran Social Services, which performs short term crisis intervention, has seen a significant increase. Legal Aid reports increases in requests for help with evictions for nonpayment of rent, bankruptcy, and foreclosure (Legal Aid does not assist with the latter two categories). Tri-Cities Chaplaincy reports that their referral rate is up by $33 \%$ due to layoffs. Catholic Family Services has noticed a drop in volunteers, but since they serve mainly lower income groups who are generally not Hanford employees, they have seen little or no change in case load.

The overall picture that emerges is that those services most likely to be impacted by direct job Tosses at Hanford appear to have been affected, but except for a few cases, the general community has not yet felt the impact. Most of the agencies emphasized that during the late winter months a different picture may begin to emerge as households begin to exhaust their savings and other resources. The $\mathbf{N}$ Reactor Closure Study noted, for example, that impacts on AFDC show up 18 months to two years following job losses.

\subsection{LOCATION OF SERVICE DEMANDS}

Table 2.14 shows that the geographical pattern of job losses for direct Hanford employees was very close to the values predicted for Nuclear Materials Production in the $\mathbf{N}$ Reactor Closure Study, despite the fact that many of the actual losses occurred in the BWIP mission. The slightly heavier concentration of the actual values in the Tri-Cities themseives (especially Richland) can be attributed to the fact that many (58\%) of the scientists and engineers and senior managers at Hanford live in the core municipalities near Hanford. Nearly 40\% of those workers answering the exit survey were in these categories. Scott, et al. noted that scientists and engineers made up over half of the BWIP workforce at the end of FY 1986 (September 1986).

A different body of data on residences of exiting Westinghouse Hanford and Kaiser Engineers Hanford (KEH) workers was compiled from company employment records between January 1 and August 21, 1988 and is shown in Table 2.15. From this larger body of data, a very similar picture emerges. In the raw data, there was a very large component of the workers reported living outside of Benton, Frank] in, and Yakima Counties (about 15.5\%). Investigation of the method of data compilation showed that many of these workers were reported at a forwarding address rather than their previous local address. When the distribution of existing workers was adjusted to account for this fact, the result is very close to the predicted value, as shown in the last column of Table 2.15.

(a) Data supplied by Mr. Dan Silver, Tri Cities Coordinator, Office of the Governor, November 23, 1988. 
TABLE 2.14. Residence of Departing Hanford Workers Compared with Predicted Values, May 9-November 11, 1988

Richland
Kennewick
Pasco

Subtotal

Hest Richland

Benton City

Prosser

Other-Benton or

Franklin Counties

Total, Benton and Franklin Counties

Other Locations and Missing Total

$\frac{\text { Predicted Value (a) }}{\text { Number }} \quad \begin{aligned} & \text { Percent } \\ & \text { of Total }\end{aligned}$

253

178

49

480

41.6

29.4

8. 0

79.0

30

25

11

\section{0}

4.2

1.8

$\frac{0}{546}$

$\frac{0.0}{90.0}$

10.0

100.0

61

607 \begin{tabular}{cc} 
Actual Value \\
\hline Number & Percent \\
of Total
\end{tabular}

284

176

33

46.8

29.0

5.4

493

81.2

31

20

5.1

3.3

0.8

5

0.8

$\frac{5}{554}$

91.3 $\frac{53}{607}^{(b)}$

8.7

100.0

(a) Predicted values based on percentages of direct employees working in nuclear materials production at Hanford in November 1986 as recorded in the $\mathrm{N}$ Reactor Closure Study (Scott, et al. 1987). Actual values were those Westinghouse Hanford workers leaving the company between May 9 and November 11, 1988.

(b) A total of 1 missing values was recorded for current residence of the Westinghouse Hanford respondents. Most "other locations" were in the Yakima Valley.

Source: Scott, et a1., 1987, Table B.14, and Hanford Worker Exit Survey Results, May 9-November 11, 1988. 
IABLE 2.15. Residence of Exiting Hanford Workers Based on Westinghouse Hanford Company and Kaiser Engineers Hanford Company Employment Records, January 1, 1988 to August 21, 1988

Richland

Kennewick

Pasco

Subtotal

West Richland

Benton City

Prosser

Other-8enton or

Frankl in Counties

Tota1, Benton and

Frank1 in Counties

other Locations

and Missing

Total

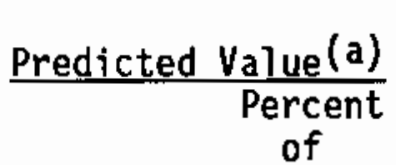

Number

676

478

130

1,284

81

68

28

$\frac{0}{1,461}$

162

1,624
Adjusted

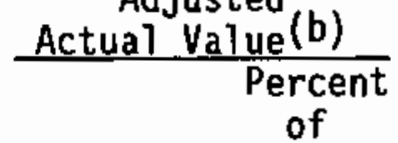

Number Total

Total

710

496

43.7

29.4

8.0

79.0

$-139$

1,345

30.5

8.6

82.8

5.0

4.2

1.7

68

4.2

4.0

68

1.7
0.5

93.3

(a) Predicted values based on percentages of direct employees working in nuclear materials production at Hanford in November 1986 as recorded in the N Reactor Closure Study (Scott, et a). 1987), Table B.14. Actual values were those Hanford workers leaving Westinghouse and Kaiser between January 1 and August 21, 1988.

(b) Adjusted values were obtained by proportionately reallocating 236 workers shown as living outside of Benton, Franklin, and Yakima counties in the raw values to locations in the three counties. 



\subsection{CHANGES IN THE NEXT 12 MONTHS}

A year after the start of major layoffs at Hanford, the Tri-City economy is showing surprising resilience. The new addition to Columbia Center has recently opened, the Coliseum is completed, and several food processing firms have either moved into the area or have announced plans to do so. For Benton and Frankl in County farmers, the agricultural picture is brighter than it has been for the past several years. In spite of these welcome developments, the prospects are for greater reductions in non-Hanford employment over the next year.

\subsection{EXPECTED DEVELOPMENTS AT HANFORD DURING 1989}

The next twelve months are expected to show some additional net decrease in the level of employment at Hanford. Working on a fiscal year basis, DOE's Richland Operations Office forecasts that between 500 and 900 Hanford job slots will be lost between September 30, 1988 and September 30; 1989 (FY 1989). The exact Hanford budget by program, and the consequent timing and number of job losses is dependent on reallocations of Department of Energy funds for which Congressional approval is required. Consequently, the extent and timing of job losses at Hanford is uncertain at this time (see Table 3.1). Hanford Site payroll can be expected to fall by approximately the same proportion as site jobs; however, the presence of 300 voluntary retirees in this group can be expected to reduce the potential negative effects of the lost positions on the local service sector. Also, many of the job losses are not expected until the end of the second quarter of the fiscal year (March 30, 1989), delaying the potential "ripple effect" on the rest of the comnunity.

TABLE 3.1. Anticipated Changes at the Hanford Reservation, Recent History and Next Twelve Months

\begin{tabular}{|c|c|c|c|c|c|}
\hline \multirow[b]{2}{*}{ Category of Direct Effect } & \multirow[b]{2}{*}{$\begin{array}{l}\text { Sept enber } \\
30.1987 \\
\end{array}$} & \multirow[b]{2}{*}{$\begin{array}{l}\text { Sept naber } \\
30.1988 \\
\end{array}$} & \multicolumn{3}{|c|}{ Projected Values. FY 1989} \\
\hline & & & $\begin{array}{l}\text { Decenber } \\
31.1988 \\
\end{array}$ & $\begin{array}{l}\text { March 31, } \\
1909 \\
\end{array}$ & $\begin{array}{c}\text { June-septenber } \\
1989\end{array}$ \\
\hline $\begin{array}{l}\text { Henford Employent by Mission:(a) } \\
\text { Nuclear Materibls Production } \\
\text { Defense Material and Emiron- } \\
\text { mental Restoration }\end{array}$ & $\begin{array}{l}6,400 \\
2,900\end{array}$ & $\begin{array}{l}5,100 \\
3,200\end{array}$ & $\begin{array}{l}5,000 \\
3,200\end{array}$ & $\begin{array}{l}4,900 \\
3,300\end{array}$ & $\begin{array}{l}\text { Progren Detail } \\
\text { Not Available }\end{array}$ \\
\hline $\begin{array}{l}\text { Basal t Waste Isolation Project } \\
\text { Nuclear Energy RED } \\
\text { Other }\end{array}$ & $\begin{array}{l}1,300 \\
1,300 \\
2,600 \\
\end{array}$ & $\begin{array}{r}200 \\
1,300 \\
2,600 \\
\end{array}$ & $\begin{array}{r}100 \\
1,300 \\
2,600 \\
\end{array}$ & $\begin{array}{r}100 \\
1,300 \\
2,600 \\
\end{array}$ & \\
\hline Total & 14,500 & 12,400 & 12,200 & 12,200 & $11,500-11,900$ \\
\hline $\begin{array}{l}\text { Average Ourterty Henford } \\
\text { Resident Enployment }\end{array}$ & 13,500 & 11,550 & 11,250 & 11,200 & $10,600-10,950$ \\
\hline
\end{tabular}

(a) Enplopment projections relate to the end of the qurter.

Source: Computed from data supplied by Doe Richland operations office. 


\subsection{PROJECTED EMPLOYMENT IN THE TRI-CITIES}

This section presents projections of employment and personal income for 1989. As mentioned above, the possibility of additional funding from Congressional actions during FY 1989 creates a degree of uncertainty that necessitates two employment projections. This pair of cases was considered to examine the sensitivity of total area employment to potential changes at Hanford during 1989. (Significant additional funding for site restoration is currently pending Congressional action. Approval would favorably influence the current employment forecast.)

A "high employment" case assumes total FY 1989 job losses at Hanford are about 500. Using quarterly average employment levels, this assumption translates into a drop of about 300 resident workers between the fourth quarter of calendar 1988 and the fourth quarter of calendar 1989 (see Table 3.1). A "low employment" case assumed Hanford job losses over the fiscal year of 900 . As in the first case, these losses were translated into quarterly averages for the estimated number of Hanford workers living in Benton or Franklin counties. From the fourth quarter of 1988 to the fourth quarter of 1989, this translation yields a projected decline of about 650 workers. Without any specific information for the final quarter of calendar 1989, it was assumed Hanford employment levels would remain constant.

\subsubsection{The Non-Hanford Basic Sector}

Only slight growth is expected in the rest of the basic sector during 1989. About 100 jobs are assumed to be added to total food processing industry, brought about by the opening of the Cascade Columbia Foods plant in Kennewick. (8) Based upon telephone contacts with the other major firms in the Tri-Cities (WPPSS, Boise-Cascade, Sandvik Special Metals, and Advanced Nuclear Fuels), total employment as a group is expected to rise only marginally during 1989 , perhaps by 50 jobs.

The expansion of Columbia Center is a bright spot in the Tri-Cities employment picture. After accounting for the jobs lost at the old Sears store in Pasco, approximately 400 new jobs have been created with in the new portion of the mall thus far. We have assumed that half of these jobs continue to be supported by the additional business that is attracted from outside the area. For 1989 , we have assumed that this figure would increase by about $25 \%$, or about 50 jobs. This judgement was based on additional business that may be attracted by the opening of Shopko and by scheduled events at the Coliseum.

No other important changes are expected in the rest of the basic sector employment during calendar 1989. There will be some delayed effect of the increase in agricultura] income during calendar year 1988. As discussed in Appendix $A$, the local economy continues to get a modest boost from the growth in government retirement payments.

(a) An underlying assumption regarding food processing is that a normal crop year is experienced in 1989. 


\subsubsection{Projected Employment by Major Sector}

Table 3.2 summarizes the projections for the high employment case through the fourth quarter of $\mathrm{CY}$ 1989. Table 3.3 refers to the low employment case and is identical with the exception of the last three quarters. A]1 numbers in the tables represent quarterly average figures; as mentioned in section one, quarterly averages help to smooth out some of the month-tomonth fluctuations that show up in the historical monthly data.

The projections are contingent upon the assumptions regarding Hanford and the remainder of the basic sector, as discussed above. The most uncertainty revolves around the projection of employment in the secondary sector--primarily housing construction, trade, finance, services, and government. Based on the examination of historical employment information and state-level economic models, we estimate that in the high employment case that about 450 jobs will be lost in this sector over the coming year. With a greater employment losses at Hanford, that figure might climb to about 600 over the same period (see Table 3.3). Most of these losses are due to the repercussions of the Hanford reductions that have already taken place. Thus, the reductions in secondary employment in 1989 in the two cases are not highly sensitive.

IABLE 3.2. Total Resident Employment, Tri-Cities Area, Recent History and Next Twelve Months, High Employment Case, Seasonally Adjusted

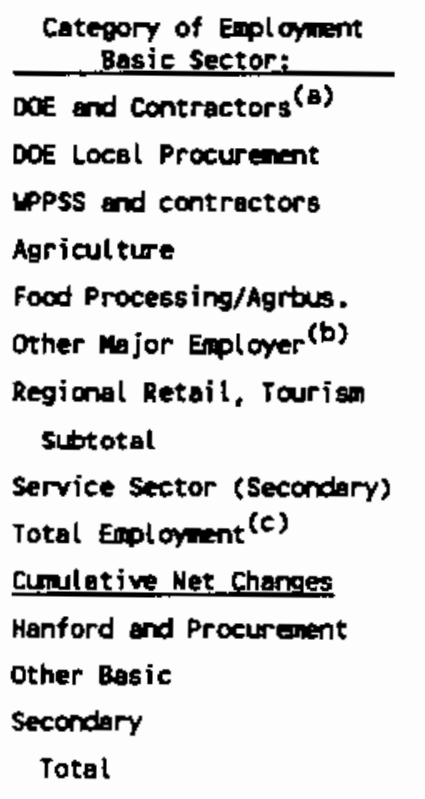

\begin{tabular}{|c|c|c|c|c|}
\hline $\begin{array}{l}\text { Decenber } \\
30,1988 \\
\end{array}$ & $\begin{array}{l}\text { March } \\
31.1989\end{array}$ & $\begin{array}{c}\text { June } \\
30, \quad 1989 \\
\end{array}$ & $\begin{array}{l}\text { Septeiber } \\
30.1980\end{array}$ & $\begin{array}{l}\text { Decesiber } \\
30,1989\end{array}$ \\
\hline 11,250 & 11,200 & 10,950 & 10,950 & 10,550 \\
\hline 800 & 800 & 800 & 800 & 800 \\
\hline 1,600 & 1,600 & 1,600 & 1,600 & 1,600 \\
\hline 5,900 & 5,900 & 5,900 & 5,900 & 5,900 \\
\hline 3,950 & 3,950 & 4,000 & 4,050 & 4,050 \\
\hline 3,950 & 3,950 & 4,000 & 4,000 & 4,000 \\
\hline 2,200 & 2,250 & 2,250 & 2,250 & 2,250 \\
\hline 29,650 & 29,650 & 29,500 & 29,550 & 29,550 \\
\hline 31,300 & $3 t, 150$ & 31,000 & 30,550 & 30,850 \\
\hline 60,950 & 60,800 & 60,500 & 60,500 & 60,400 \\
\hline & -50 & -300 & -300 & -300 \\
\hline & 50 & 150 & 200 & 200 \\
\hline & $-\uparrow 50$ & -300 & -350 & -450 \\
\hline & -150 & -450 & -450 & -550 \\
\hline
\end{tabular}

\footnotetext{
(B) Eight percent of total Hanford exployment subtracted as o residence adjustrent to account for coninters from Yakins canty.

(b) Includes exploywent at IBP (I awa Beef) and soise Cascade at Hallula, both in Halle Mel la canty.

(c) Includes only employment in Benton and frankl in Canties.
} 
expected to show up during 1989. The extent of additional impacts depends upon the severity of the job losses at Hanford in 1989.

\subsection{3 offsetting Factors}

What factors would serve to offset these impacts over the next year? Several can be cited. The first involves any major underestimate of changes within the basic sector. As we mentioned above, we have no reliable--and current--information on the farm sector. In 1986 farm proprietors' income in Benton and Franklin counties was nearly $\$ 70$ million dollars. After a relatively poor year in 1987, many farm product prices were up in 1988. Farm income is estimated to have approached record levels in 1988. Although there is the possibility that farm income might increase again in 1989, we have assumed in the forecast that farm income will remain at current levels.

The second factor involves the possibility of an increased percentage of purchases that are made locally. The growth of the retail sector around Columbia Center not only attracts more visitors from outside the Tri-Cjties but also helps to retain more spending within the community by local residents. This is especially the case as retail competition increases and the variety of goods and services expands. It is difficult to measure the impact that any shift in spending patterns might have. Over the next year, it is unlikely that this effect would do much more than support some of the new jobs just created at the Center. We estimate any effect would result in the increase of fewer than 100 jobs.

In summary, these factors, even if fully realized, are unlikely to completely offset the delayed repercussions of the 1988 layoffs at Hanford. The simple fact is that these job losses have reduced personal income and purchasing power within the Tri-Cities economy that is essential to maintaining stability in local earnings and employment. Unless new basic sector activities are found to replace these losses and/or the leakages of spending goods and services on secondary goods and services to establishments outside the bi-county area are effectively reduced, the overall employment picture will continue to weaken. The Tri-City labor market currently displays hopeful signs of a long-term rebound as economic diversification proceeds. Nevertheless, even if additional Hanford activity during 1989 can offset many of the job losses associated with the $\mathrm{N}$-Reactor (as exemplified in the high employment scenario) the overall employment picture can be expected to be even weaker a year from now than it is today.

\subsubsection{Persona] Income}

The projected declines in total area employment are mirrored in the projections of wage and salary income and total personal income. In 1986, the last year for which official estimates are available, wage and salary income in Benton and Franklin Counties was about $\$ 1.3$ billion (about 1.4 billion in 1988 dollars). Total personal income, which in addition to wages and 
salaries includes fringe benefits, interest, dividends, proprietors' income, and government transfer payments, was $\$ 1.9$ billion (about 2.1 billion in 1988 dollars).

Table 3.4 shows annual estimates and projections of wage and salary income and total personal income over the perjod 1986 through 1989. The figures are all expressed in terms of constant 1988 dollars to remove the effect of overall price inflation. The historical figure for 1987 can only be considered approximate since we have no direct information for most of the individual components. The personal income projections for 1988 and 1989 are driven by projected changes in wage income, government transfer payments, and farm proprietors' income. Between calendar year 1988 and 1989 wage and salary income in the area is projected to decline between $2.6 \%$ (high employment case) and $3.5 \%$ (low employment case). The projected reduction in personal income is somewhat less than that (ranging from 0.9 to $1.5 \%$ ), since several other sources are somewhat independent of the area's wage and salary income. Increases are expected in government and private pension payments. On a calendar year basis, farm income is projected to be higher in 1989 that during 1988 ( see Appendix A).

\subsection{POPULATION}

As it has for most of the 1980s the Tri-City area faces the prospect of continuing declines in total population over the next few years. Outmigration, as a consequence of fewer job opportunities, will likely be greater than the natural increases in the population from demographic factors.

Projecting migration changes is subject to a high degree of uncertainty. In the $1987 \mathrm{~N}$ Reactor Closure Study a migration-employment "multiplier" was used to estimate the long-run impact on population from a loss in jobs at Hanford. Specifically, we assumed that about 1.3 people would leave the area for every job lost. This estimate was derived from an analysis of population-employment changes in Benton and Franklin counties from 1981 to 1986 associated with the downturn at WPPSS and from survey information related to the likelihood employees within certain broad occupational categories would migrate.

TABLE 3.4. Wage and Salary Income and Total Personal Income (millions of 1988 dollars)

$\begin{array}{lccc}\text { Year } & \begin{array}{c}\text { Wage and } \\ \text { Salary Income }\end{array} & & \begin{array}{c}\text { Total Personal } \\ \text { Income }\end{array} \\ 1986 & \$ 1,401 & & \$ 2,133 \\ 1987 & 1,405 & 2,143 \\ 1988 & 1,344 & 2,096 \\ 1989 & 1,309 & 2,077 \text { High Employment } \\ & 1,297 & 2,064 \text { Low Employment }\end{array}$


Several factors complicate the task of making projections of population migration over a short forecast horizon. First, the previous analysis did not focus on the time-phased response of migration to employment. A decision to migrate hinges on various factors, including: 1) job markets in other areas of the country, 2) the local housing market, and 3) expectations of recovery in the local economy. All three would influence how long before a move out of the area would be made after loss of a job. Given these factors, we believe that projections based on the previous experience from WPPSS downturn can be judged only as suggestive.

A second factor concerns the behavior of outmigration in 1986 and 1987 , prior to the recent Hanford layoffs. The estimates provided by the Washington State Office of Financial Management indicate that outmigration was still occurring in Benton and Franklin counties in the last few years, in spite of marked improvements in the overall employment picture. Whether this migration is the tail end of a long adjustment process from the WPPSS downturn, a result of other demographic trends affecting other more rural counties within the state, or is simply a result of statistical errors in the estimation procedure, cannot be determined.

Table 3.5 shows the Apri1 1 population estimates for the historical period 1985-1988 and projections for 1989 and 1990, while Table 3.6 shows the distribution of the changes among cities. As explained in Appendix A, estimates of outmigration from the declines in area employment are superimposed on top of three other components: 1) births, 2) deaths, and 3) a constant outmigration reflecting underlying trends. The magnitudes of all of these components are based on 1986-1988 data.

The population projections shown in Table 3.6 apply only to the low employment case. In the high employment case, approximately 200 additional people would be spread across these jurisdictions.

TABLE 3.5. Benton and Franklin County Population, History and Projections (April 1 estimates)

\begin{tabular}{ll} 
Year & \multicolumn{1}{c}{ Population } \\
\cline { 2 - 2 } 1985 & 144,000 \\
1986 & 140,000 \\
1987 & 139,600 \\
1988 & 139,600 \\
1989 & 139,000 \\
1990 & 138,300 (High employment case) \\
& 138,100 (Low employment case)
\end{tabular}


TABLE 3.6. Changes in Tri-Cities Area Population: Recent History and Next Two Years, Low Employment Case

\begin{tabular}{|c|c|c|c|c|c|}
\hline \multirow[b]{2}{*}{ City or County } & \multirow[b]{2}{*}{$\begin{array}{c}\text { Apri1 } 1, \\
1986 \\
\end{array}$} & \multirow[b]{2}{*}{$\begin{array}{c}\text { Apri1 1, } \\
1987 \\
\end{array}$} & \multirow[b]{2}{*}{$\begin{array}{c}\text { April 1, } \\
1988 \\
\end{array}$} & \multicolumn{2}{|c|}{ Projected Values } \\
\hline & & & & $\begin{array}{c}\text { April 1, } \\
1989 \\
\end{array}$ & $\begin{array}{c}\text { Apri1 } 1, \\
1990 \\
\end{array}$ \\
\hline $\begin{array}{l}\text { Richland } \\
\text { Kennewick } \\
\text { West Richland } \\
\text { Benton City } \\
\text { Prosser } \\
\text { Benton County } \\
\text { Pasco } \\
\text { Frankl in County }\end{array}$ & $\begin{array}{r}30,240 \\
36,600 \\
3,720 \\
1,820 \\
4,010 \\
104,000 \\
18,420 \\
35,300\end{array}$ & $\begin{array}{r}30,280 \\
37,320 \\
3,700 \\
1,815 \\
4,000 \\
104,100 \\
18,520 \\
35,500\end{array}$ & $\begin{array}{r}30,140 \\
37,180 \\
3,670 \\
1,800 \\
3,990 \\
104,100 \\
18,430 \\
35,500\end{array}$ & $\begin{array}{r}29,800 \\
36,950 \\
3,650 \\
1,770 \\
3,980 \\
103,550 \\
18,350 \\
35,450\end{array}$ & $\begin{array}{r}29,400 \\
36,630 \\
3,590 \\
1,730 \\
3,970 \\
102,800 \\
18,220 \\
35,300\end{array}$ \\
\hline
\end{tabular}

\subsection{PROJECTED HOUSING VALUES}

The decline in housing values experienced in the Tri-Cities during 1988 is expected to continue at a more modest pace into 1989 . Besides the recent modest increases in mortgage interest rates, which will affect the ability of some borrowers to qual ify for loans, the prospects in the local economy are for continued decline in jobs and income, especially in the second half of the year, which will put additional downward pressure on prices. Although about 300 of the Hanford jobs scheduled to be "lost" by residents of Benton and Franklin counties during FY 1989 actually will be retirements and therefore will have a lesser effect on the housing market, other Hanford and service sector job slots will be lost and should result in more houses on the market as these people leave. The recent stabilization in prices probably will prevail for the first part of calendar year 1989. However, it is expected that the additional Hanford job losses and ancillary service sector job losses, together with the expected decline in population, will result in a decrease in average housing prices about half as large as 1988's decrease. This decrease should occur toward the latter half of the year. The average price on single family homes will probably decline from a 1988 value of $\$ 58,200$ to between $\$ 57,100$ and $\$ 57,600$. 


\subsection{REFERENCES}

Benton County Assessor. Issues 1981-1988. Benton County Taxes. Prosser, Washington.

Federal Home Loan Bank of Seattle. 19B8. Washington Housing Vacancy Survey. (June). Seattle, Washington.

Frankl in County Assessor. 1988. 1987 Assessments for 1988 Taxes. (Plus previous six issues, 1981-1986 Assessments.) Pasco, Washington.

Scott, M.J., D.B. Belzer, R.J. Nesse, R.W. Schultz, P.A. Stokowski, and D.C. Clark. 1987. The Economic and Community Impacts of Closing Hanford's N Reactor and Nuclear Materials Production Facilities, PNL-6295. Pacific Northwest Laboratory, Richland, Washington.

State of Washington, Office of Financial Management (OFM). 1988. 1988 Population Trends for Washington State, PB8-09, Population Estimating and Forecasting Unit, 0Tympia, Washington.

State of Washington, Employment Security Department. Monthly issues from January 1987-November 1988. Washington State Labor Area Summaries. 01ympia, Washington.

State of Washington, Economic and Revenue Forecast Council. 1988. Economic and Revenue Forecast for Washington State (September 1988). Olympia, Washington.

U.S. Department of Commerce. 1986. Business Statistics. U.S. Government Printing Office, Washington D.C.

U.S. Department of Commerce. 1988. Survey of Current Business. (June). Bureau of Economic Analysis, Washington D.C.

U.S. Department of Labor. 1988. Monthly Labor Review. (May). U.S, Government Printing Office, Washington, D.C. 

APPENDIX A

METHODOLOGY FOR EMPLOYMENT AND POPULATION FORECASTS 


\section{APPENDIX A}

\section{METHODOLOGY FOR EMPLOYMENT AND POPULATION FORECASTS}

This appendix provides a description of how the forecasts of employment, population, and tax revenues were constructed. The forecast methodology in general follows the same approach as PNL's 1987 analysis of economic impacts of a possible $N$ Reactor closure (Scott et al., 1987). The work in this ongoing monitoring effort differs from the earlier study in several ways: 1) the basic economic information is updated from 1986, and 2) more concern is given to short-run timing of impacts.

Section A.1 describes the updates and revisions in the information used to identify the basic and secondary sectors. Section A.2 discusses the approach used to forecast secondary employment. Section A.3 compares predicted employment with actual employment for the four quarters starting with the fourth quarter of 1987. Sections A.4 and A.5 describe how the personal income, and population forecasts were linked to the predicted changes in total employment.

\section{A.I UPDATED ESTIMATES OF THE BASIC AND SECONDARY SECTORS}

In PNL's previous analysis of the $N$ Reactor closure, an attempt was made to provide a detailed breakdown of the Trj-Cities economy into basic and secondary sectors for a recent period. In that study calendar year 1986 was chosen as a reference point. In this first monitoring report, the third quarter of 1987 is chosen as a reference period.

Table A.l compares the previous estimates of the basic and secondary sectors with revised and updated data for the third quarter of 1987 (1987:3). Major differences are highlighted below.

DOE and Contractors (Hanford). Prior to the recent major layoffs, DOE and contractor employment in the third quarter of 1987 was only slightly higher than the average for 1986. Based upon the personnel location analys is performed in the previous report, $8 \%$ of total employment was assumed to live outside the Tri-Cities area (Benton or Franklin Counties). Thus, the 13,200 and 13,450 figures both represent $92 \%$ of all workers who work for any one of the DOE prime contractors or in DOE's Richland operations office.

In fiscal year 1986 (October 1985 through September 1986), DOE and its contractors purchased approximately $\$ 50$ million of goods and services in the Tri-Cities. The 1987 study estimated that this procurement supported about 800 jobs in Benton and Franklin counties. Given that direct Hanford employment changed little between 1986 and the third quarter of 1987 , it is assumed in the present study that the same number of jobs were being supported in the local economy from procurements. 
TABLE A.1. Comparison of Basic and Secondary Employment, 1986 Versus Third Quarter 1.987 (1987:3)

\begin{tabular}{|c|c|c|}
\hline Basic & 1986 Employment (a). & 1987:3 Employment \\
\hline $\mathrm{DOE}$ and Contractors & 13,200 & 13,450 \\
\hline $\begin{array}{l}\text { Loca) Procurement } \\
\text { (direct employment) }\end{array}$ & 800 & 800 \\
\hline WPPSS and Contractors & 1,700 & 1,650 \\
\hline \multicolumn{3}{|l|}{ Agriculture } \\
\hline $\begin{array}{l}\text { Proprietors } \\
\text { Employees } \\
\text { Agri-Business } \\
\text { Food Processing }\end{array}$ & $\begin{array}{l}2,500 \\
3,900 \\
1,200 \\
2,400\end{array}$ & $\begin{array}{l}2,300 \\
3,600 \\
1,200 \\
2,650 \text { (b) }\end{array}$ \\
\hline Other Major Employers & 1,930 & 3,850 \\
\hline Tourism & 1,900 & 1,900 \\
\hline Retirees & N/A & N/A \\
\hline Total Basic & 29,530 & 31,400 \\
\hline Total Secondary & $\underline{32,570}$ & $\underline{31,700}$ \\
\hline $\begin{array}{l}\text { Total Resident } \\
\text { Employment }\end{array}$ & 62,100 & 63,100 (b) \\
\hline
\end{tabular}

(a) Source is Table B.6 in (Scott, et al. 1987). Primary sources are given in the 1987 report.

(b) Seasonaliy adjusted from quarterly averages published by Washington State Employment Security Department.

Washington Public Power Supply System (WPPSS). Employment at the Washington Public Power Supply System dropped only slightly between 1986 and the third quarter of 1987. Part of this decline is from the loss of jobs at the Hanford Generating Plant (HGP); this plant utilized by-product steam from the $\mathrm{N}$ Reactor to produce electricity.

Agriculture. In the 1987 report, agricultural employment was estimated in four separate components. Data on farm proprietors and employees were taken from the U.S. Department of Commerce's Regional Economic Information System. The differences in Table A.l do not reflect a change in employment levels, but are due to revisions in the commerce estimates. The latest Commerce data are for calendar year 1986. Without having any other source of information, these estimates were assumed to be approximately the same for the third quarter of 1987. In using the annual figure, we implicitly assume 
that this is a seasonally adjusted estimate. Actual farm employment in the third quarter was certainly higher than this figure. For agri-business, the third component listed under agriculture, the estimate of 1200 jobs was held at the 1986 value for lack of more recent information. The final component, food processing, shows slightly higher employment in the third quarter of 1987 as compared to all of 1986. The 1987:3 figure is seasonally adjusted; the actual (published) employment was 2900.

Other Major Employers. The scope of other major employers has been expanded to include IBP (Iowa Beef Processors) in Wallula. IBP employs some 1,500 workers, most of whom live in the Tri-Cities. Also added was the estimated employment associated with Battelle's private (non-DOE) contract research (about 400 employees). As in the 1987 study, this category also includes Advanced Nuclear Fuels, Sandvik Special Metals, Boise-Cascade, and the railroads. (a) The total figure was adjusted downward by 300 to account for workers at IBP and Boise-Cascade who live outside Benton and Franklin Counties. This is an estimate based upon discussions with the personnel offices in these firms.

Tourism. The 1987 N Reactor closure study used an estimate of approximately 1,900 jobs supported by travel and tourism in 1986 in the Tri-Cities. Although convention business has increased since 1986 according to the Tri-City Visitor and Convention 8ureau, no attempt was made to estimate how many additional jobs this may have created in 1987. A particular difficulty with this category is that we have no single sector of the econgpy for which we can track quarter-to-quarter changes in travel-related jobs.

Retirees. As stated in the 1987 study, approximately 12,000 people over the age of 65 live in Benton or Frankl in County. In the methodology of the 1987 study, the transfer income received by these individuals was factored along with basic sector payroll in the determination of a static local multiplier. After adjustment for inflation (by use of the overall Consumer Price Index), government transfer payments increased by neariy 7\% between 1984 and 1986, largely due to the growth in the number of beneficiaries. Assuming this rate of growth has remained nearly the same since then, transfer payment income in the third quarter would have been about $\$ 141 \mathrm{million}$. As will be discussed below, an adjustment to the employment projection procedure was made to account for the Westinghouse early retirement program.

\section{A.2 METHOD USED TO PROJECT SECONDARY SECTOR JOB IMPACTS}

This section describes the general method by which secondary job impacts were projected. Five topics are discussed: 1) long-term multipliers,

(a) The source of the employment data in the present report is from a special aggregation of these firms supplied by Dean Schau of the Washington State Employment Security Department.

(b) In 1988, however, some additional employment was attributed to the increase in the number of conventions in 1988 over 1987. See Section A.3. 
2) time-phasing of multiplier response, 3) computational approach, 4) seasonal adjustment, and 5) income and other adjustments to basic employment changes.

\section{A.2.1 Long-Term Multipliers}

As in the $1987 \mathrm{~N}$ Reactor Study, the general method of determining job impacts from the loss of jobs in the basic sector is through the use of an employment "multiplier." The multiplier is a ratio, defined generally as:

Change in the Total Number of Jobs Change in Jobs in the Basic Sector

The focus of much of the 1987 study was to develop estimates of such multipliers, both at the state and local levels. A variety of economic models were used to estimate these multipliers and an effort was made to reconcile the various values generated by the different approaches. Most of the emphasis in the 1987 study was on long-term total employment multipliers, e.g., the ultimate impact on the total number of jobs after al1 economic interactions have had time to be completed. The information produced by several of the modeling approaches suggested that these interactions may require as long as three to five years to be completed.

Based upon the various model results and subsequent analysis, point estimates of the most probable long-term total local and state multipliers were made. At the state level a value of 2.5 was used and at the local (bicounty) level a value of 2.2 was used. Another way of looking at the local multiplier is that for every resident of Benton or Franklin County who loses his job at Hanford, 1.2 other (secondary) jobs in these two counties will al so eventually be lost. Thus, in contrast to a total multiplier which includes the direct job loss, a secondary employment multiplier can be defined as $2.2-1.0=1.2$.

In the current study, parts of the basic dat; have been revised and updated, as reflected in Table A.l discussed above. One of the economic models was rerun to determine the change in the estimated multipliers. The differences were deemed insufficient to warrant any major reassessment of the long-term multipliers.

\section{A.2.2 Time Phasing of Multiplier Response}

Unfortunately, the various models used in estimating the long-term multipliers shed little light on how these multipliers would be manifested over time. That is, if the secondary employment multiplier is 1.2 and 1,000 jobs are lost in the basic sector, how fast will the projected 1,200 jobs in the secondary sector be lost?

The available information on the pattern of responses over time of secondary employment to basic employment comes from two sources. The first is the quarterly WASHMOD econometric model of the State of Washington. The 
second is regression analysis of historical annual Tri-City employment data. In the short-run forecast methodology, we have put somewhat more emphas is on the latter source.

The regression analysis performed in the $1987 \mathrm{~N}$ Reactor study suggested that about half of the secondary job impact would be felt in the first year of any Hanford layoffs. The remainder of the impact was estimated to occur over an extended period, according to a slowly declining geometric sequence. A problem is that inferring the timing on a quarterly basis is blurred by the use of only annual data. (a) Some experimentation with annual aggregations of quarterly data suggested that on a strict quarterly basis, somewhat more than half of the response would occur in the first four quarters after a drop in basic employment in a particular quarter. For this study, we have assumed that the impacts on secondary employment will extend four years and that about $55 \%$ of the response is in the first year.

Even after these assumptions are made, there is considerable uncertainty as to how the responses in the first year are spread out. In the 1987 study, the responses were assumed to be equal across all quarters of the year following the drop in basic employment. In the current analysis, we assume that the responses begin to decline after the first six months or so. (B) We also assume that the response in the second quarter following any change in basic employment is higher than the first. This assumption stems from the presumption that unemployment insurance and previous savings would help to maintain expenditure levels higher in the first months after a layoff, as compared to subsequent time periods.

The resulting pattern of time-phased secondary employment multipliers is shown in Figure A.1. The first quarter's multiplier is 0.09 ; the second quarter's multiplier is 0.20 , and so on. The cumulative response after any quarter is simply the sum of the previous multipliers. Thus, to use the oneyear reference point as described above, the sum of the first four multipliers is $\mathbf{0 . 6 5}$. The total sum of the time-phased multipliers is 1.2 , the value corresponding to the long-run secondary employment multiplier.

\section{A.2.3 Computational Approach}

To use the time-phased multipliers to estimate the effects of quarterto-quarter changes in basic sector jobs, the study uses the following procedure. The projection of secondary job changes involves calculating the

(a) The optimal solution to this problem is to reestimate these equations on a quarterly basis. Unfortunately, some of the basic data to estimate Supply System and contractor employment levels by quarter would be very difficult to reconstruct. In addition, some thorny problems with deseasonalizing the data would have to be overcome.

(b) This time pattern of behavior is consistent with the results of the state econometric model, WASHMOD. 


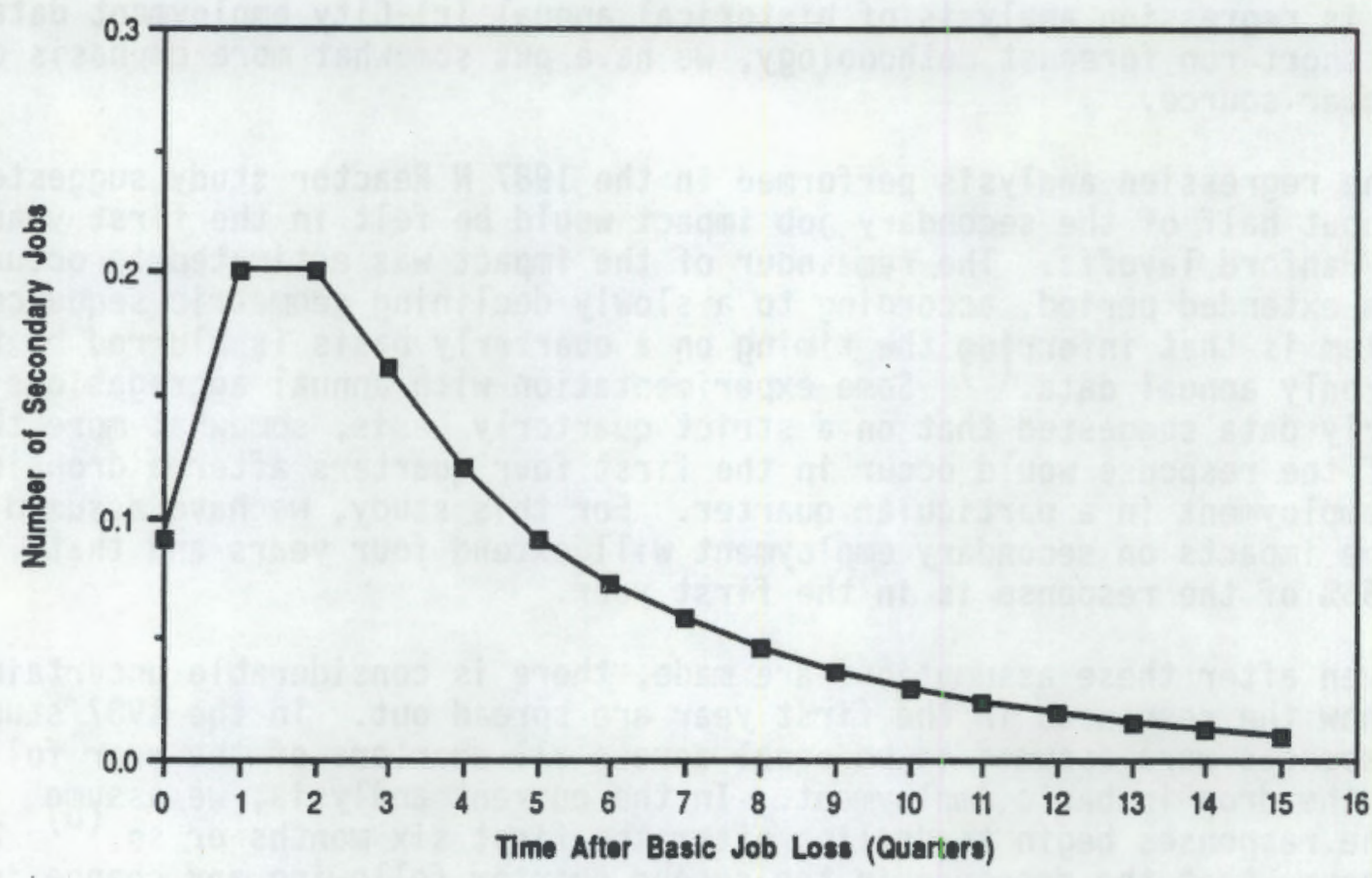

FIGURE A.1. Time-Phased Employment Multiplier

product of the time-phased multipliers with basic sector employment levels in previous quarters. Formally, secondary employment is calculated by the following expression:

$$
\begin{aligned}
S_{t} & =a+\text { Summation }\left[m_{i} * B_{t-j}\right] \\
\text { where } i & =0,1,2 \ldots 15 \\
S_{t} & =\text { secondary employment in quarter "t" } \\
a & =\text { constant term } \\
& =\text { time-phased multiplier for quarter } t-i \\
m_{i} & =\text { gasic employment in quarter } t-i \\
B_{t-i} & =\text { baster } t, \\
(\text { e.g., } B t & =\text { employment in quarter } \\
B_{t-1} & =\text { employment in quarter prior to quarter } t \text {, etc.) }
\end{aligned}
$$

To initiate the process, the third quarter of 1987 was chosen as the base period and basic employment estimates for the previous fifteen quarters were constructed. The above equation was then used to generate an estimate of secondary employment in the base period (1987:3). This involves calculating the cross product of the time-phased multipliers with the lagged 
values of basic employment. The constant term (a) is then adjusted to make the calculated value equal to the historical value in the third quarter of 1987.

The forecast for the four quarters beginning in the fourth quarter of 1987 is made in the same manner. The equation above utilizes the given (current) quarter's value of basic employment together with the previous fifteen quarters of basic employment. The year starting in 1987:3 provides a foundation upon which to examine the forecasting accuracy of the simple economic base approach. This topic is discussed below.

The forecasts presented in Section 3 of the report start from a base period of the fourth quarter of 1988 . The constant term is adjusted again to yield a zero error in that quarter. Thus, the forecast of secondary employment changes is based on both the changes in basic employment that are projected to occur into 1989 and the history of basic employment changes that have occurred since 1985.

\section{A.2.4 Seasonal Adjustment}

All quarterly employment figures in the report are shown on a seasonally adjusted basis. Some attention to seasonal adjustment is necessary, primarily due to the large agricultural component in Benton and Frankl in Counties. Retail, education, and service sectors also display significant seasonal shifts by quarter.

Seasonal factors for total resident employment were estimated on the basis of quarterly data from 1983 forward. Additive seasonal factors were estimated by use of a difference from moving average technique. (a) Table A.2 shows total reported employment, seasonal factors, and seasonally adjusted employment for 1987 and 1988 .

In constructing the historical series of basic employment that was used in the forecasting equation, employment in food processing was seasonally adjusted in a similar manner. The remaining components of the basic sector were assumed to be al ready seasonaliy adjusted. Thus, for example, projected increases in retail employment are assumed to occur on top of any normal seasonal change that could be expected.

(a) Seasonal factors were computed using the SEAS (A) procedure in the TSP Micro-econometric package (from Quantitative Micro Software, Irvine, California). These factors would be similar, but likely not exactly match, those calculated from the more elaborate $X-11$ procedure used by the Census Bureau. Note that the seasonal factors reflect the difference of each quarter from the annual average. Thus, to obtain, the seasonally adjusted figure, one subtracts the seasonal factor from the published value. 
TABLE A.2. Total Employment and Seasonal Factors for Benton and Frankl in Counties, 1987-1988 (quarterly averages)

\begin{tabular}{lccc} 
Quarter & $\begin{array}{c}\text { Published } \\
\text { Employment }\end{array}$ & $\begin{array}{c}\text { Seasonal } \\
\text { Factor }\end{array}$ & $\begin{array}{c}\text { Seasonally } \\
\text { Adj. Employment }\end{array}$ \\
$1987: 1$ & 59900 & -3620 & 63520 \\
$1987: 2$ & 68200 & 4917 & 63283 \\
$1987: 3$ & 64100 & 936 & 63164 \\
$1987: 4$ & 60900 & -2233 & 63133 \\
$1988: 1$ & 59100 & -3620 & \\
$1988: 2$ & 66300 & 4917 & 62720 \\
$1988: 3$ & 61900 & 936 & 61383 \\
$1988: 4$ & 58700 & -2233 & 60964 \\
\hline
\end{tabular}

Note: Published employment is the quarterly average of monthly figures estimated by the Washington State Employment Security Department, rounded to the nearest 100 jobs.

The forecast of total employment in Table 3.3 is constructed as a seasonally adjusted estimate. To determine the actual changes in employment from one quarter to the next, the changes in seasonal factors shown in Table A.2 would have to be incorporated.

\section{A.2.5 lncome and Other Adjustments}

One major difference between the previous study and the current one involves the definition of the basic sector employment. In the 1987 study only changes in the Hanford employment were considered. The focus was on determining the impact of employment changes at Hanford on the local and state economies. The current study includes a forecast of Tri-City employment, which depends upon changes in employment and income in other basic sectors besides Hanford. For example, government transfer payments to retirees constitute an important element of the basic sector, even though no employment is associated with this income. To maintain the multiplier concept of the prior study, the basic sector employment actually used in the forecasting procedure is adjusted to account for this income and other factors. The major adjustments to the basic sector employment are described below.

Accounting for Relative Wage Differences. The employment multipliers developed in the $1987 \mathrm{~N}$ Reactor study were designed to apply to changes in Hanford employees only. The present study expands the scope of the earlier work by projecting the response to the entire basic sector, in which changes occur in both Hanford and non-Hanford employment. The key issue is whether the multiplier is the same for a Hanford worker earning $\$ 35,000$ per year as compared to a retail store employee who earns half or less of that figure. 
Lacking any other information, the assumption for this study is that the multiplier impact for non-Hanford workers is roughly proportional to their average annual (wage) income. In essence, the basic sector employment used in the forecasting equation above is put in terms of "Hanford-equivalent" employees. Average annual wages in 1987 for DOE and contractor employees was about $\$ 35,000$. Thus, an employee in a sector in which average wages are about \$17,000 would be measured as one half of a Hanford employee. In other words non-Hanford workers are weighted in proportion to their average earnings as compared to an average Hanford employee.

The earnings weights for the non-Hanford employees are based roughly on the earnings data collected in the $1987 \mathrm{~N}$ Reactor report. (a) In assigning weights to non-Hanford categories of the basic sector, the judgment was that great precision was not called for in light of the degree of uncertainty in the overall procedure. Accordingly, the following weights were assigned to the non-Hanford employment categories:

$\begin{array}{ll}\text { Procurement-related } & 0.75 \\ \text { Food processing } & 0.50 \\ \text { Other major employers } & 0.75 \\ \text { Tourism/Retail } & 0.50\end{array}$

Government Transfer Payments. As discussed in the 1987 study, retirees make up a significant portion of the economic base of the community. In 1986, it was estimated that government transfer payments in the form of retirement benefits made up nearly $15 \%$ of the total basic sector income. According to information from the Social Security Administration, the number of social security recipients in Benton and Franklin Counties has been growing on average by about $3.5 \%$ per year since 1983 . Using $\$ 138 \mathrm{mil1}$ ion dollars as a measure of government pension benefits in calendar year 1986, the growth in the beneficiary population translates into about a $\$ 1.2 \mathrm{million}$ dollar increase in aggregate income per quarter from this source.

To incorporate the impact from this source, this income has been converted to an "Hanford-equivalent" employment measure by dividing government pension income by $\$ 35,000$. Using this approach, the growth in the beneficiary population is equivalent to an increase of about 35 Hanford-related jobs per quarter. One can speculate as to various reasons why the multiplier impacts from these two sources would differ per dollar of income. However, without evidence to the contrary, we assumed that their impacts on secondary employment are roughly the same.

Farm Income. According to Department of Commerce estimates, 1986 farm proprietors' income in Benton and Franklin counties was $\$ 68$ million. More

(a) See Table B.6 in (Scott et al., 1987).

(b) Average annual earnings in the 1986 report for this category was estimated to be $\$ 33,700$. The weight was assumed to be only 0.75 in this study because of the addition of relatively lower paid workers at IBP. 
recent estimates from this source are not expected until 1990. (a) To extrapolate the 1986 estimate, we developed a rough measure of total farm production value in the two counties for 1986, 1987, and 1988. Based on data from the Washington State Department of Agriculture, values of production were summed for the following crops: 1) wheat, 2) barley, 3) corn, 4) hay, 5) potatoes, 6) asparagus, 7) sweet corn (b 8 ) onions, 9) apples, 10) cherries, 11) concord grapes, and 12) wine grapes. (b) The five 1argest crops are estimated to be potatoes, corn, wheat, apples, and grapes.

The value of farm production based upon this data was estimated to have declined about $10 \%$ between 1986 and 1987 and to have risen nearly $25 \%$ between 1987 and 1988. Less confidence must be attached to the 1988 estimates since we do not have the latest production estimates for all crops nor season average prices. Nevertheless, these estimates are consistent with anecdotal evidence that farm income is up in 1988 relative to the past several years. Prices for wheat, potatoes, and apples are all up substantially from a year ago. An unknown element of error is associated with using value of production as a direct indicator of changes in net farm income.

To incorporate farm income into the forecasting methodology, the annual estimates were interpolated to quarterly values through the end of 1987 . The $25 \%$ increase from the 1987 to 1988 was phased in through 1988 in the following manner: 1988:2, up $5 \%$; $1988: 3$, up $15 \%$, and 1988:4, up $25 \%$. Tota] farm income used in the projection of secondary employment was then:

$\begin{array}{ll}1988: 1 & \$ 59.9 \text { million } \\ 1988: 2 & \$ 62.9 \text { million } \\ 1988: 3 & \$ 68.9 \text { million } \\ 1988: 4 & \$ 74.9 \text { million }\end{array}$

Values for 1989 were held at the fourth quarter 1988 levels.

Similar to government pension income, this income was been converted to a "Hanford-equivalent" employment measure by dividing farm proprietors' income by $\$ 35,000$. Using this approach, the growth in farm income during 1988 was equivalent to an increase of about 400 Hanford-related jobs. Again, one can speculate as to various reasons why the multiplier impacts from these two sources would differ per dollar of income. However, without evidence to the contrary, we assumed that their impacts on secondary employment are roughly the same.

(a) The Department of Commerce estimates of personal income, from which farm proprietors' income is separately estimated, are made every other year on a county basis. The 1986 estimates were released in April 1988.

(b) Information was taken primarily from Washington Agricultural Statistics, 1985-1986 and 1986-1987 editions. Most price data for 1988 was taken from the October 18 issues of "Washington Agri-Facts," a monthly news release prepared by the Washington Agricultural Statistics Service. 
Early Retirement Program. As part of the consolidation of the Hanford contractors and in the face of declining program budgets, the Westinghouse Hanford Company instituted an early retirement program in the summer of 1988 . As of the end of fiscal year 1988 (September 30) approximately 200 workers had left jobs at Hanford under this program. About 300 additional workers have also signed up for this program. To take advantage of the provisions of the program, they must resign by March 30, 1989.

Because of the compensation provisions of the early retirement program, and given the fact that most workers taking advantage of this program would likely be in relatively higher pay scales, it has been assumed that the pension incomes of these new retirees would be comparable to the total wage income of an equivalent number of Hanford employees. To incorporate this assumption into the forecasting procedure for secondary employment we have added back into basic sector employment for each quarter from 1987:4 through 1989:1 10\% of the change in DOE and contractor employment (i.e., 200 early retirements divided by a total change of 2,000 employees). Beginning the second quarter of 1989, 300 "Hanford equivalent" workers are added to the basic sector, which offsets a large proportion of the projected total reductions in Hanford employment in that quarter.

In essence, over the two-year period starting in the third quarter of 1987, we have assumed that the income losses due to the total DOE and contractor reductions in employment may be offset by about one-sixth due to early retirements. About one-sixth of the payroll losses from the drop of 3,000 or so Hanford workers may be offset by the early initiation of pension benefits to the approximately 500 early retirements.

\section{A.3 ANALYSIS OF RECENT EMPLOYMENT CHANGES}

In light of PNL's $\mathbf{N}$ Reactor Closure Study released in the summer of 1987, a question that is being increasingly asked is why hasn't there been more of an impact on the rest of economy from the Hanford cutbacks? Many readers of that study may recall that a major finding of that study was that about 1.2 other jobs would be lost in the Tri-Cities for every job lost at Hanford. From the roughly 2,200 bi-county resident jobs lost at Hanford thus far, one interpretation of the previous study is that we should have seen a decline in non-Hanford employment of 2,650. Instead, the published employment figures indicate that only several hundred jobs have been lost outside of Hanford.

\section{A.3.I Major Issues}

Three issues must be addressed to try to resolve this apparent inconsistency. The first issue relates to the time phasing of the response of jobs in the secondary sector to changes in the basic sector. As is sometimes

(a) This estimate is also predicated on the assumption that most of these retirees remain in the Tri-Cities. The exit survey described in Section 2 of the report suggests that this is the case. 
overlooked in the 1987 study, the full impact of any Hanford cutbacks was expected to take several years or longer to be fully realized. These lags occur because consumers don't immediately reduce expenditures when income declines (or is lost via a layoff) and neither do employers immediately reduce staff when sales decline. Unfortunately the empirical evidence regarding these lags is scanty, and what evidence that does exist may not apply well to the particular situation in the Tri-Cities.

The second issue involves the behavior of segments of the economy outside of Hanford. As Table 2.5 shows, the non-Hanford basic sector is est $i$ mated to have grown by 400 jobs over the 1987:Q3-1988:Q4 time frame. To maintain some consistency with the 1987 study, the tables in this report continues to focus on the interrelationship of employment changes in the various segments of the economy. In reality, incomes and spending drive the employment picture in the secondary sector. As intimated in section 2.3, increases in farm income, growth in the general retirement population, and early retirement programs for Hanford workers all helped to maintain overall spending in the Tri-cities during 1988. (a) None of these sources of income can be directly tied to current employment. (a)

The third issue involves interpretation of the available employment statistics. One aspect of this issue involves employment changes in industries that we normally think of as only secondary. As explained Section 2.4.1, maintaining a distinction between basic and secondary sectors requires us to view changes in employment in any particular industry with caution. Published changes in secondary employment in the retail industry may include offsets to losses of "normal" retail employment by estimated changes in employment involved in regional retailing (i.e. becoming part of the basic sector).

Another aspect of this third issue involves the statistical uncertainty of the primary published data. Nearly all of the employment data used in this report are preliminary in the sense that they are dependent upon a sample of firms in each industry. Revised and final employment figures are based upon tax data supplied by most firms to $01 y$ mpia, a by-product of the state unemployment insurance program. These revisions to the 1987 data will not available until early in 1989. Benchmark revisions for the 1988 data will not be available until early in 1990. What relevance does this have to this study? On occasion, the differences in year-over-year changes from the preliminary total employment estimates to the final estimates have been as much as 1\%. Applied to the roughly 30,000 workers in the secondary sector, a revision of this magnitude would be approximately 300 workers, a large figure in comparison to the estimated change in Table 2.5. Any deficiencies in the sampling framework are magnified when large numbers of firms are entering or leaving the market, a situation that may characterize the latter part of 1988.

(a) By farm income we mean income to farm owners. The number of farmers shown as part of the basic sector employment cannot serve as a short term indicator of farm income due to variability of farm product prices. 


\section{A.3.2 Decomposing Recent Employment Change}

With these issues in mind, a natural question is how can we explain the events of 1988. By using the time-phased multipliers and estimates of the components of the basic sector, the employment projection model was used to simulate the period from 1987:03 through 1988:Q4.

Two different simulations were performed. In the first, all components of the basic sector were set at their historical values in each quarter. Using the time-phased multipliers as discussed in the section A.2.2, secondary employment was forecast for each quarter from the fourth quarter of 1987 through the fourth quarter of 1988. As described above, there are unfortunately sufficient uncertainties in the exact nature of the multiplier lags and in the estimates of the "actual" sector employment to preclude any type of formal validation of the projection methodology. Accordingly, this initial simulation could be classed as a calibrating simulation. Some minor experimentation of the lag structure was undertaken to yield reasonable similarity to the approach used in PNL's $1987 \mathrm{~N}$ Reactor study. The adjust ments were well within the confidence intervals suggested by prior statistical analysis. The final set of time-phased multipliers continue to imply that, in the long run, about 1.2 jobs in the secondary sector are lost for each job loss at Hanford.

The second simulation is an impact analysis, similar to that performed in the $1987 \mathrm{~N}$ Reactor Closure report. Here only Hanford basic employment was allowed to change; the time phased multipliers were used again to project secondary employment by quarter through 1988.

The results of these simulations are shown in Table A.3. By the third and fourth quarter the predictions of the time-phased multiplier analysis are reasonably close to the secondary employment estimates developed from the published resident employment numbers. By the fourth quarter, the forecasting methodology would have indicated a drop of 573 jobs. Rounded to the nearest 50 as in the main text tables, this translates into a drop of 550 jobs.

Without including the growth in non-basic Hanford sector or applying any of the income adjustments described in the previous section, employment would have fallen by 983 (or, again, a rounded estimate of 1000). Thus, following the rounding procedures used el sewhere in the report, the effect of the offsetting factors is roughly 450 jobs $(1000-550)$. Given the overall uncertainties in the underlying information, perhaps a more appropriate estimate would indicate that about half of the potential impact of 1,000 jobs was offset from other factors, i.e. about 500 jobs.

Before much is made of any comparison of predicted versus published as a measure of model performance (i.e. lines one and two of Table A.3), one should also keep in mind the difficulty in accurately measuring total employment in a local area such as the Tri-Cities. A closer look at three months of published total employment figures in the Tri-Cities (Benton and 
TABLE A.3. Secondary Employment: Impact Versus Forecast

1987:3 Through 1988:4 (seasonally adjusted)

\begin{tabular}{|c|c|c|c|c|c|c|}
\hline & $1987: 3$ & $1987: 4$ & 1988:1 & $1988: 2$ & 1988:3 & 1988:4 \\
\hline $\begin{array}{l}\text { Computed from } \\
\text { Published Data }\end{array}$ & 31785 & 31957 & 31857 & 31162 & 31271 & 31273 \\
\hline $\begin{array}{l}\text { Projection Methodology } \\
\text { with offsets }\end{array}$ & 31785 & 31775 & 31730 & 31611 & 31417 & 31212 \\
\hline $\begin{array}{l}\text { Impact Case--No } \\
\text { Offsets }\end{array}$ & 31785 & 31760 & 31671 & 31477 & 31170 & 30802 \\
\hline
\end{tabular}

Frankl in Counties) leads us to conclude that comparisons of model-predicted employment and actual employment can only be considered suggestive at this point in time.

Table A.4 shows the 1987 and 1988 total employment estimates for the months of July, August, and September. Along with tota $\}_{\text {a }}$ yesident employment the number for total nonagricultural jobs are included.

Perhaps the most striking aspect of Table A.4 is the magnitude of monthly fluctuations in the year-over-year changes in employment. Part of the explanation lies in differences in food processing employment which

TABLE A.4. Total Resident and Nonagricultural Jobs--Recent Monthly Estimates (published estimates--not seasonaliy adjusted)

\begin{tabular}{lcc} 
& Total Employment & Total Nonagriculture \\
\cline { 2 - 3 } Jufy 1987 & 64,600 & 55,900 \\
July 1988 & 63,200 & 53,500 \\
Change & $-1,400$ & $-2,400$ \\
August 1987 & 63,500 & 55,790 \\
August 1988 & 60,600 & 52,840 \\
Change & $-2,900$ & $-2,950$ \\
September 1987 & 64,200 & 56,120 \\
September 1988 & 61,800 & 53,880 \\
Change & $-2,300$ & $-2,240$
\end{tabular}

(a) Total employment pertains to all residents of Benton or Franklin counties who were employed during the month. Total nonagricultural jobs refers the number of jobs in these two counties. Some of these jobs could be filled by residents of other counties. 
differ slightly from one year to the next. Another component involves different government programs during the summer months that can distort underlying trends. Finally, as was mentioned above, all of the 1987 and 1988 data are preliminary in the sense that they are dependent on a sample of firms in each sector. (a) Revised and final employment figures are based on tax data supplied by most firms to 01 ympia, a by-product of the state unemployment insurance program. These revisions for the monthly 1987 data will not be available until early in 1989. Benchmark revisions for the 1988 data will appear a year later than that.

Our basic approach has been to measure secondary employment as a residual. As the discussion above indicates, the potential measurement errors in both total employment and in our own estimates of the basic sector can obscure short-term trends in secondary employment. Another approach, however, is to look closely at the nonagricultural employment data to see if changes in particular sectors correspond to our definition of secondary employment.

Table A.5 provides an approximate decomposition of the nonagriculturat employment changes over the fourth quarter of 1987 to the fourth quarter of 1988. The first three columns are taken or caiculated from the Employment Security Oepartment estimates. Column four attributes the drop of some 2,100 Hanford workers into three major sectors--Chemicals, Construction, and Business Services. In this context, the total number of Hanford job losses is used, not just losses estimated for area residents. Column five suminarizes our judgment concerning other changes in the basic sector. The increase of 30 jobs in primary and fabricated metals is assumed to be in the basic sector.

The increases of 250 jobs in the retail sector and 50 jobs in miscellaneous services is assumed to be associated with the higher volume of convention business reported in 1988 as compared to 1987 and the opening of the Columbia Center expansion. These are the assumptions described in Section 2.4.1.

The last column in Table A.5 shows the remaining change by sector, after the estimates of basic employment have been accounted for. The largest drops occur in business services, other services, and in public education. The net change across all sectors is about 470 workers. This estimate compares favorably with the estimated drop of 500 secondary workers from 1987:03 to 1988:04 using the residual calculation method and resident employment data as described above. Comparing strictly from 1987:04 to 1988:Q4, the resident employment method implies a drop of about 700 . Given the quality of the

(a) More variation can be expected in the resident employment figures, since they depend, in part, on a survey of households that is conducted on a statewide basis. According to Dean Schau, the area economist for the Washington State Employment Security Department, this factor may be responsible for the rather low estimate of resident employment change for July. 
TABLE A.5. Fourth-Quarter Change in Nonagriculture Employment, Fourth Quarter 1987--Fourth Quarter 1988 (averages of monthly published estimates)

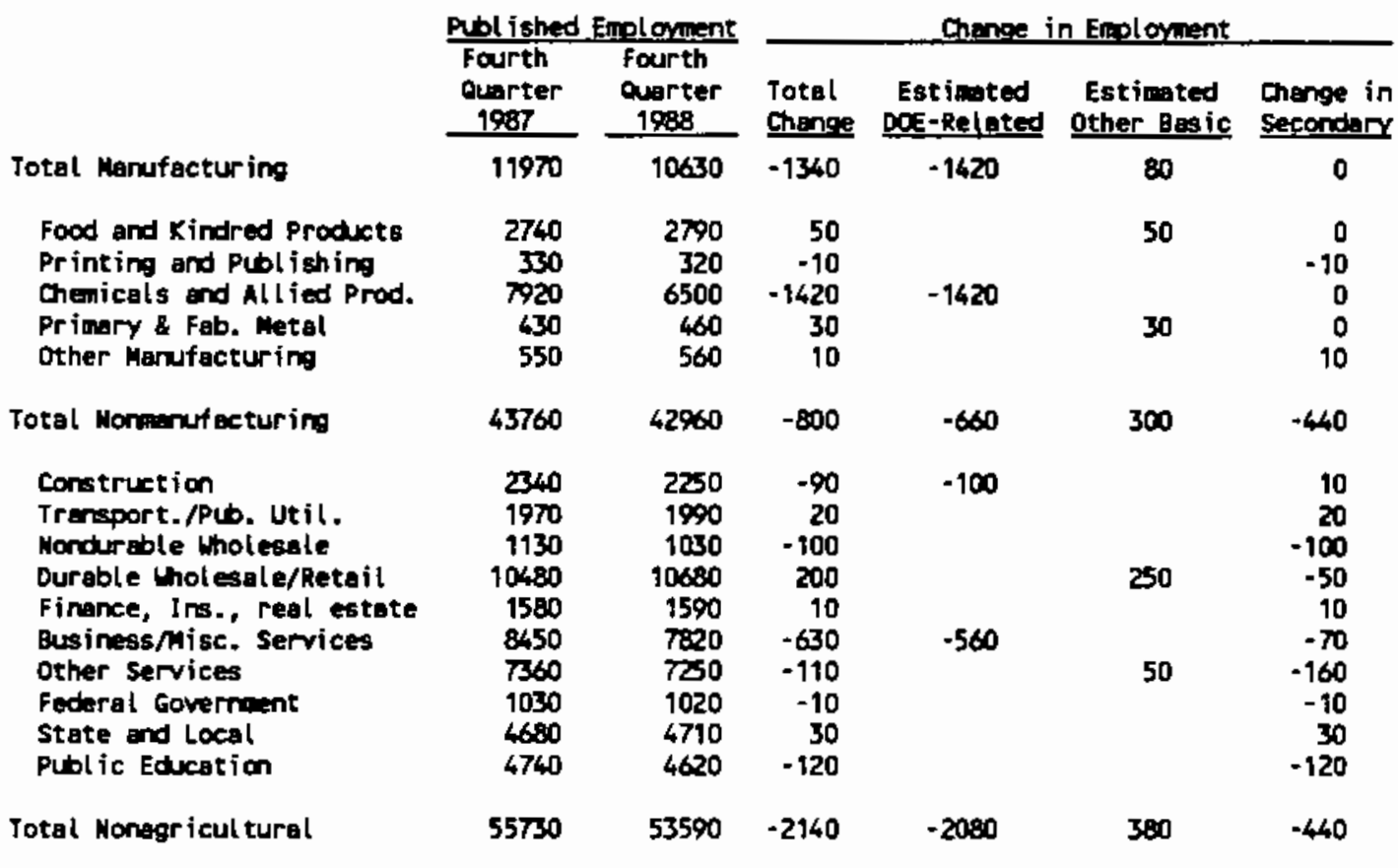

Source: Published enployment from Uashington State Emplament Security Departinent.

existing information there is no simple way to provide a better reconciliation of the two sources. One should again be remindful that both of these figures are based on the preliminary estimates by the Employment Security Department.

\section{A.4 PERSONAL INCOME}

Total personal income in Benton and Frank] in counties was nearly $\$ 2$ billion dollars in 1986, the latest year for which official government estimates are available. Since all historical data are reported on an annual basis and because these projections are intended to drive annual projections of tax revenues, the personal income projections were done only on an annual basis. Since the last official estimate is 1986, the projection methodology must al so be employed to estimate 1987 .

Although the Bureau of Economic Analysis in the Department of Commerce distinguishes over 20 components of personal income in the historical estimates, the projection methodology uses only six major categories: 1) wage income, 2) farm proprietors' income, 3) government transfer payments for retirees, 4) dividends interest and rent, 5) unemployment benefits, and 
6) a11 other income. The last category includes such items as fringe benefits, non-farm proprietors' income, and other types of government transfer payments.

The projection procedure is straightforward. An estimate of wage income in the bi-county area is constructed as the sum of payrolls of the total basic sector and the secondary sector. The average annual wage income in the basic sector is about $\$ 35,000$ and in the secondary sector is about $\$ 15,000$. The projected basic and secondary employment is multiplied by these two wage levels, respectively, and then summed to generate total annual income.

Both farm proprietors' income and government transfer payments are already treated separately as part of overall projection of the basic sector. These components were discussed in the previous section.

The total of dividends, interest, and rent (\$273 million in 1986) is projected by the use of a statistical equation. Historical annual data on dividends, interest, and rent (DIR) was related to two variables: 1) total Benton and Franklin County wage income, and 2) the national total for dividends, interest, and rent. Based on this relationship, a $1 \%$ increase in local wage and salary income has been accompanied historically by $0.85 \%$ increase in dividends, interest, and rent. A $1 \%$ increase in national dividends, interest, and rent has been associated with a $0.26 \%$ increase in area income from these same sources. Although this procedure is somewhat crude, lack of data prevents much more sophisticated approaches from being pursued. In any event, this procedure does capture the principal influences: 1) wage income as a proxy for investment by local residents, and 2) national dividends, interest, and rent which reflect general interest rates.

In 1986 the total of the remaining components of personal income was $\$ 183$ million. There is no simple method to make credible projections of many of the other components of personal income at a local level. For this study, it was assumed that income from these sources together would move proportionately to total wage income.

The above projection methodology was used to generate an historical estimate of personal income for 1987. For 1988 and 1989 a simpler approach was used that linked directly to the methodology used in predicting the change in secondary employment. In effect, we apply the annual changes in income, $1987 / 1988$ and 1988/1989 that are used in computing "Hanford equivalent" employment described in section A.2.5. Thus, 1988 personal income is equal to the 1987 estimate of personal income plus: 1) the change in total wages and salaries, 2) the change in other labor income (calculated as $9.5 \%$ times wages and salaries, 3) the change in government transfer payments, 4) the change due to Hanford workers taking early retirement, and 5) the change in farm income. Table A.6 summarizes these changes for 1988 and 1989.

The positive change in farm income for 1989 is still consistent with our assumption that farm income does not grow beyond the fourth quarter of 1988 . Income is calculated to be higher, on average, in the four quarters of 1989 as compared to 1988 . 
IABLE A.6. Components of Change in Personal Income, 1987-1988 and 1988-1989, Low Employment Case (millions of $\$ 1988$ )

\begin{tabular}{|c|c|c|}
\hline Component & $\underline{1987-1988}$ & $1988-198$ \\
\hline Wages and Salaries & -60.9 & -46.7 \\
\hline 0ther Labor Income & -5.8 & -4.4 \\
\hline $\begin{array}{l}\text { Government Transfer } \\
\text { Payments }\end{array}$ & +5.4 & +5.6 \\
\hline Hanford Early Retirement & +4.7 & +4.5 \\
\hline Farm Income & +9.6 & +9.4 \\
\hline Tota] & -47.0 & -31.6 \\
\hline
\end{tabular}

This procedure implies that we hold dividends, interest, and rent (DIR) and non-farm proprietors' income constant at 1987 levels. These components have likely moved in offsetting directions with DIR increasing and proprietors' income declining. Further work will be required to analyze these components in more detail and to incorporate their impact on total local employment.

\section{A.5 POPULATION CHANGE}

In the $1987 \mathrm{~N}$ Reactor study, a migration-employment "multiplier" was used to estimate the long-run impact on population (in Benton and Franklin counties) from a loss of jobs at Hanford. This estimate was derived from two independent approaches. The first approach related the estimated migration from 1981 through 1986 to the drop in area employment. The second approach looked at the likelihood employees within certain broad occupational categories would migrate. This approach used data collected as part of the 1980 population census.

Akin to the issue of how fast the secondary sector adjusts to changes in basic employment is how migration responds over time after the loss of jobs within the local economy. Unfortunately, the only source of information on the timing question specific to the Tri-Cities is from the WPPSS experience. As we mentioned in the body of the report, drawing strong quantitative conclusions from this one episode should be avoided. A decision to migrate depends upon various factors, including: 1) job markets in other areas of the country, 2) the prospects for selling a house, and 3) expectations of recovery in the local economy. In several of these respects, the situation in 1988 is markedly different from 1982-1983. 
With these caveats in mind, we turn to the historical data to see if they can provide any guidance to the future. Table A.7 shows employment and population in the bi-county area from 1981 through 1988 . Compared to the 1987 report, column one in Table A.7 shows the average employment in the first quarter of the year, rather than the annual average. The first quarter is used as it represents a period corresponding more closely in time to the April 1 population estimates that are prepared by the state office of Financial Management (OFM). The approach is to relate the annual population changes measured for April 1 to the changes in employment over the same time period.

The employment numbers in the table were not seasonally adjusted, and thus the levels are slightly lower than the annual averages.

Total employment as measured in the first quarter peaks in 1981 . By the first quarter of 1985, total employment had fallen by over 18,000 jobs. The employment picture began to turn around in 1986. The decline in 1988 represent the first round of Hanford layoffs that started in the fall of 1987 .

The OFM population estimates for Benton and Franklin counties are shown in column three. The year 1980 represents a true count of population as part of the last official census. The subsequent estimates are based on a variety of indicators including school enrollment, automobile registrations, and housing vacancy rates. The uncertainty level associated with these estimates is not known.

TABLEA.7. Population and Employment Changes in Benton and Franklin Counties, 1980-1988

\begin{tabular}{|c|c|c|c|c|c|c|c|c|c|}
\hline Year & $\begin{array}{l}\text { Total } \\
\text { Emplogy) } \\
\text { ment } \\
\end{array}$ & $\begin{array}{c}\text { Change } \\
\text { fram } \\
1981 \\
\end{array}$ & $\begin{array}{l}\text { Total } \\
\text { Popu- } \\
\text { lotion }\end{array}$ & $\begin{array}{l}\text { Mmual } \\
\text { Change }\end{array}$ & Births $^{(b)}$ & Deaths & Migration & $\begin{array}{l}\text { Cumulative } \\
\text { Migration }\end{array}$ & $\begin{array}{l}\text { Cumlative } \\
\text { Migration/ } \\
\text { Cumulat ive } \\
\text { Employment } \\
\text { Change } \\
\end{array}$ \\
\hline 1980 & $-\cdot$ & -- & 144669 & $\cdots$ & $\cdots$ & $\cdots$ & -. & -- & -. \\
\hline 1981 & 73233 & -. & 147200 & 2731 & 2983 & 765 & 513 & 0 & -. \\
\hline 1982 & 71700 & -3533 & 147900 & 700 & 2801 & 856 & -1245 & -1245 & 0.35 \\
\hline 1983 & 61067 & -14166 & 144700 & -3200 & 2986 & 727 & -5459 & .6704 & 0.47 \\
\hline 1984 & 58133 & -17100 & 146000 & -700 & 3243 & 774 & -3169 & -9873 & 0.58 \\
\hline 1985 & 56767 & -18466 & 140900 & -3100 & 2745 & 807 & -5038 & .14911 & 0.81 \\
\hline 1986 & 58667 & -16566 & 139300 & -1600 & 3142 & 662 & $-40 B 0$ & -18991 & 1.15 \\
\hline 1987 & 59933 & -15300 & 139000 & 300 & 2148 & 1078 & -770 & -19761 & 1.29 \\
\hline 1988 & 59100 & -16133 & 139600 & 0 & 2499 & 926 & -1573 & -21334 & 1.32 \\
\hline
\end{tabular}

(a) Total enployent is neasured as the overage of first quarter resident enploynent.

(b) Births and deeths fron 1981-1985 are annul overeges for these four years. 
The change in population shown in column four can be split into three components: births, deaths, and migration. Births and deaths can be fairly precisely measured on a county basis. Migration is then computed as a residual or balancing element. The nature of the overall estimation process implies that sma11 relative errors in the measurement of population can be reflected in large errors in migration.

The annual estimates of migration after the 1981 employment peak are cumulated in column eight. Based on the official estimates, net migration out of the area has continued even after the labor market began to improve in 1986, albeit at lower levels than previously.

The last column in the table shows the cumulative migration since 1981 divided by the change in area total employment over the same period. In the previous report, we chose the 1981-1986 figure to represent the long-run migration-employment multiplier. Based on the different definition of employment in this study (first quarter as compared to annual average), the multiplier over this particular period is slightly lower, 1.15 versus the previous 1.3. As the previous estimate of 1.3 relied on survey evidence as well the time series analysis, there seems no strong reason to change the earlier estimate.

What is clear, however, from the more detailed year-by-year figures shown in the last column of Table A.7 is that migration responds only very gradually to a major drop in employment. In particular, perhaps less than a third of the full response occurs in the first year. This is not surprising due to the impediments to moving out of the area that most people face-finding a new job, selling a house, waiting until the end of a school year.

What is not so clear from Table $A .7$ is exactly how to use the results to forecast future migration (and consequentiy population) changes. The numbers in the last column of the table cannot be used directly if we assume that each "vintage" of layoffs has its own time profile of migration. We are inclined to prefer a model of the distributed lag form used in the estimation of secondary employment above. Thus, the percentage of people migrating in 1983, for example, will be different for these two groups: 1) those losing jobs in 1982, and 2) those losing jobs in 1983 . The figure in the last column of the table, 0.47 , is an average of these underlying percentages applied to the two separate vintages.

With episodes of rising and falling employment, a standard approach would be to statistically estimate the time-phased multipliers. Lacking this type of data, the approach here is to choose a set of time-phased multipliers, at least for the first several years, that will reasonably explain the pattern of outmigration in the Tri-Cities over 1982 through 1984 . On the basis of trial and error data fitting, the following values were chosen for the short-run migration multipliers: 0.35 in the first year, 0.30 in the second year, and 0.25 in the third year. Table A.7 shows actual cumulative migration from 1982 through 1984 as -1245 in 1982, -6704 in 1983, and -9703 in 1984. Using the above multipliers, the corresponding predicted cumulative increases for these years are $-1236,-6018$, and -11118 . 
The projections of population for (April) 1989 and 1990 involved several steps. First, we assumed that there has been and will continue to be some level of outmigration unrelated to the employment declines at Hanford.

According to the OFM population estimates, some 770 people moved out of the Benton-Frank] in county area in 1986 (April 1986 to April 1987), in spite of an increase in overall employment. In 1987, some 1,600 people migrated. Some of the 1987 decline can be associated with the drop of 800 jobs in Tri-Cities between the first quarter of 1987 and the first quarter of 1988 . Based upon the analysis of multipliers from the WPPSS downturn, perhaps $20 \%$ $(0.35 \star 800)$ of these jobs might have been related to the decline in employment. This would imply that about 1,200 migrants are not directly related to the employment decline. Taking the average of the approximately 800 migrants (rounded from the 770 shown in Table A.7) in 1986 and approximately 1,200 migrants in 1987, we have assumed that roughly a net 1,000 people per year will leave the Tri-Cities over the next several years, even if the employment picture were to stabilize.

The second step involves using the time-phased multipliers to project migration from (Apri1) 1988 to 1989 and then from 1989 to 1990 . Table A.8 illustrates how the year-over-year employment changes were used in this process. The April 1990 population estimate partially depends upon projected employment in the first quarter of 1990. This projection lies outside the scope of the remainder of the report. Employment in this quarter was based on holding basic employment in 1989:4 and 1990:1 at the 1989:3 level and using the forecasting methodology as described above to project secondary employment.

The annual change in bi-county population (shown for the low employment case) is the sum of the change in Table A.8 plus the exogenous migration ( 1,000 as discussed above), plus births, minus deaths. From Table A.7 births in the 1986 and 1987 averaged a little over 2,300 per year. Deaths in the two counties were about 1,000 per year. Combined with the assumption that 1,000 people will still migrate out of the area even if employment stabilized, we estimate that these factors alone would lead to an increase of about 300 people per year. Added to the employment-related migration in Table A.8 we project a population drop of about 600 between 1988 and 1989 $(-923+300)$ and a drop of about 900 in the next year $(-1,153+300)$.

TABLE A.8. Use of Time-Phased Multipliers to Project Migration from Tri-Cities

Change in Employment

$-800 \quad-1950$

$-1050$

(low employment case)

Outmigration
$4 / 1 / 87-4 / 1 / 88$
$0.35 *-800$
$=-280$
$4 / 1 / 88-4 / 1 / 89$
$0.30 \star-800+0.35 \star-1950$
$=-923$
$4 / 1 / 89-4 / 1 / 90$
$0.25 \star-800+0.30 \star-1950+0.35 \star-1050=-1,153$ 
To compute population changes by jurisdiction, we first allocated primary and secondary employment changes in Benton and Franklin Count ies using the residence weights in Table B.14 of Scott et al. (1987). The annual "normal increase" of 300 owing to births, and exogenous outmigrants was allocated based on population lagged one year, with $90 \%$ of changes in the unincorporated areas first allocated to Benton County. 
APPENDIX B

SURVEY DESIGN 


\section{APPENDIX B}

\section{SURVEY DESIGN}

Much of the data concerning the characteristics of the Hanford workers leaving the site was collected in the Hanford Worker Exit Survey, a brief voluntary questionnaire first administered in May, 1988 by the site contractors as part of the separation process. As part of the scope of the Tri-Cities Socioeconomic Monitoring and Analys is Study, 8attelle Pacific Northwest Laboratory social science research staff talked to administrators of the survey and users of the information, examined the questionnaire's design, and redesigned and pretested the new questionnaire, which clears up some ambiguities in the old one.

\section{B.1 REVIEW OF EXIT SURVEY PROCEDURES}

The initial discussions with individuals responsible for analyzing and coding the exit survey data suggested some weaknesses in both the survey form and the way it is administered. Figure B.l shows a facsimile of the original survey form. Several of the survey questions appeared to be confusing the respondents. For example; respondents answering the question on household size (question 12) often included themselves in the total even though they were instructed not to; this results in an inflated number of reported household members. Similar problems existed with several of the other questions. Furthermore, a7though a 11 of the various Hanford contractors were implementing the survey, they were administering it in different ways. In some cases the respondent was allowed to take the survey home to complete, while in other cases the respondent answered the questionnaire in the personne] office. This variation in how the questionnaire is administered may partially explain the wide variation in response rates reported by the different contractors.

\section{B.2 EXII SURVEY REDESIGN}

In response to these concerns, Battelle staff members contacted each of the persons responsible for administering the survey to discuss how the survey instrument and process could be improved. Based on this feedback, and standard survey design principles, a draft of a new survey instrument was developed. A small scale pre-test to evaluate questionnaire wording and the ease by which the survey could be filled out was conducted using Battelle employees. Currently the redesigned questionnaire has been submitted to DOE for review and to determine if the changes to it will require office of Management and Budget clearance under Paperwork Reduction Act rules. A facsimile of the redesigned form is shown in Figure B.2.

Once a redesigned survey form is approved, we recommend that a formal pre-test be conducted to evaluate the accuracy and completeness of the 
answers we receive. This will entail orientation to the new form of all of the individuals responsible for administering the questionnaire, and instituting standardized survey implementation practices. We are confident that as a result of this survey redesign effort both the quality of data we collect and the survey response rate will improve.

OMB CONTROL NO. 1910-1100

\section{HANFORD WORKER EXTT SURVEY}

:-ocal government agencies have asked the Department of Energy to provide socioeconomic Jata as a result of layofts at Hanford. This information will be used to assist them in their planning and budgeting activities. Your help is needed in conducting this survey. Your sarticipation is completely voluntary and will be greatly appreciated.

1. Today's date:

2. Occupation:

Management

Clerical
Engineer/Scientist

Administrative/Support $\square$ Technician/Specialist

Other

3. Employer:

$\square$ Department of Energy

Westinghouse Hantord
Pacilic Northwest Lab.

Kaiser Engineers
Boeing Computer Services

Other

4. How long have you worked for this employer? (ruumber of years)

-(Employment with UNC/RHOWestinghouse Hanford Co.. and JAJ/Kasser Engineers Hanford should be considered as either Westinghouse or Kaiser service.)

7. Where do you live?

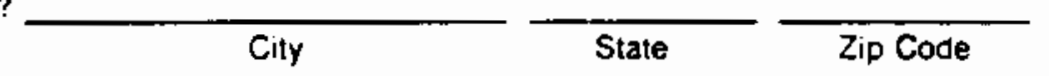

j. Do you live in the
City limits
County

7. What type of housing do you live in?
An apartment
A mobile home/trailer
A nouse
Other
A duplex

PLEASE TUPN OVER AND COMPLETE THE OTHER SIDE

BD-6000-175 (06/88)

\section{FIGURE B.1. Original Hanford Worker Exit Survey Form}


8. Do you own or rent this housing?

$\square$ Own, how long

Rent

9. How many people live in this household (including yourself)? people

10. How many household members attend?

Public School

Private School

- A preschool?

- Grade school (grades K-6)?

- Middle school (grades 7-8)?

- High school (grades 9-12)?

- College, vo-tech, etc.?

11. Which school district do you live in?

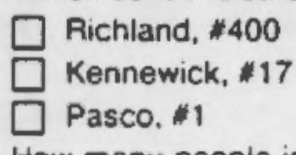

$\square$ Kiona-Benton, $\# 52$

Burbank

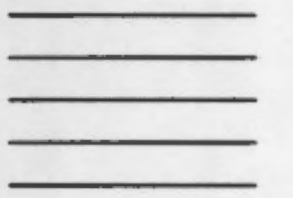

Private School

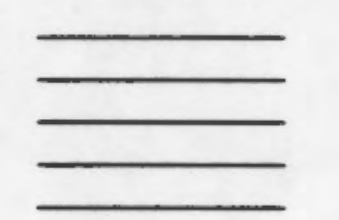

12. How many people in this household are employed (excluding yourself)?

12a. How many other household members work at Hanford?

13. Why are you leaving?

$\square$ Take retirement

Resıgnation

Reduction in force (including voluntary)

Other

14. What is your residential location or preference?

$\square$ Relocate for a new job $\square$ Stay in Tri-Cities, look for a new job

Don't know

15. If you retire, will you choose to:

$\square$ Stay in the Tri-Cities

Relocate to (if known)

Dont know

\section{City}

State

Pease Return To: Hanford Placement

Center

H9.17

BD-6000-175R (06/88)

\section{FIGURE B.1. (contd)}




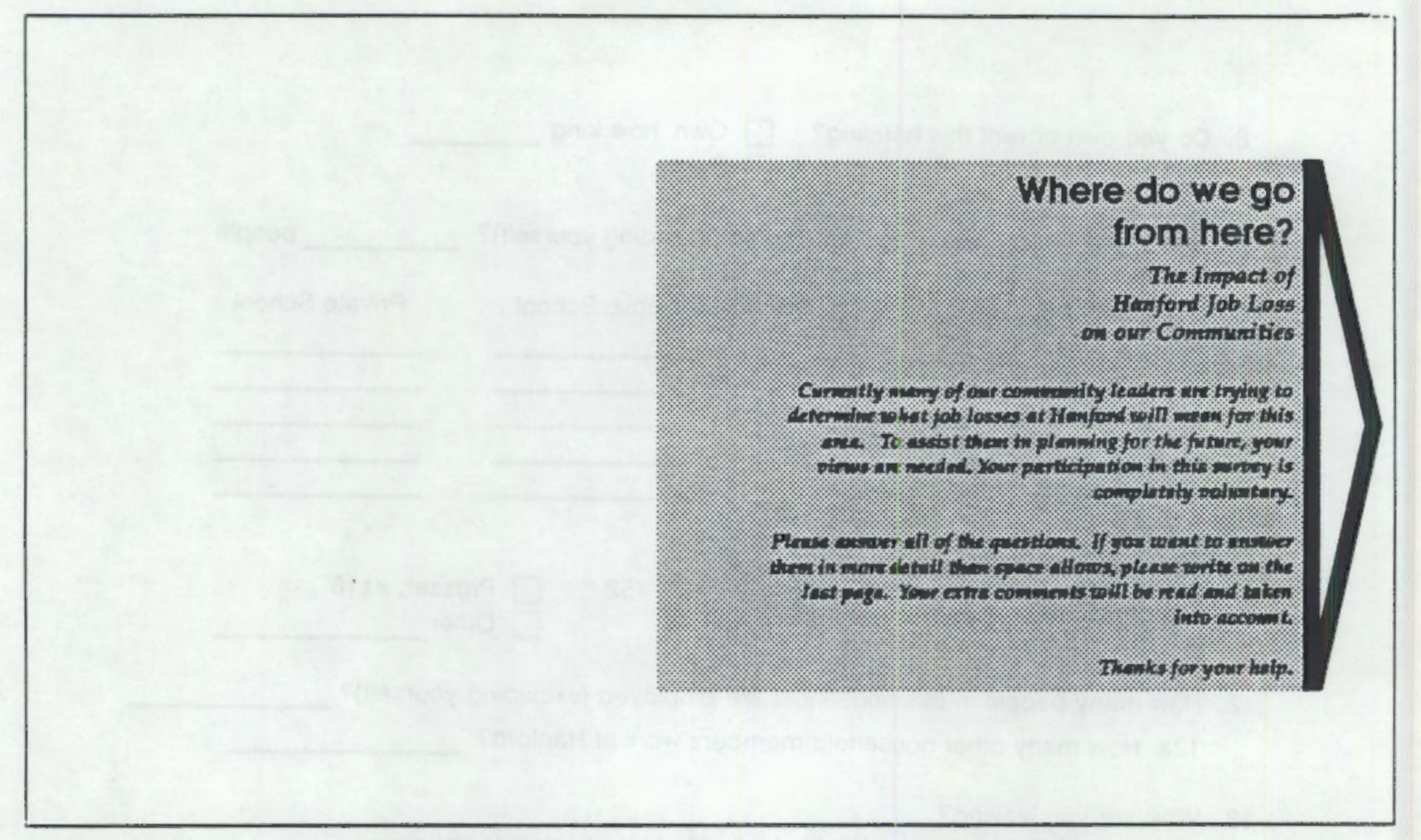

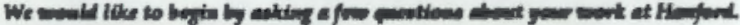
Pinave chele the mondar of your eneswer.

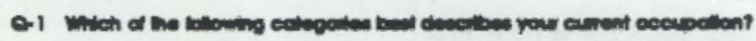
1 Cerical/Secruturlel
2 Solential/Enginee
3 Technidan
4 Mrage/Adentrietestar
5 Research Amiant
6 Other (ploen opedty)

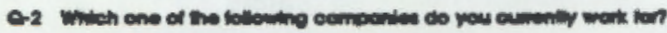
1 Wethghame Hanford
2 Kener Enginens
3 Battalle
4 US. Depermant of Enery
5 boeing Computer Serviou
6 Hanford Enviromenel Helwh Roundation

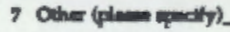

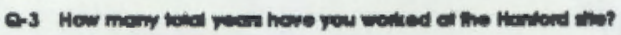
1 La then two geen
2 Two to forr yon
3 Pive to ten yor
4 Eleven to tweiny yein
5 More than twenty man

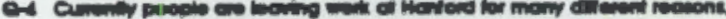

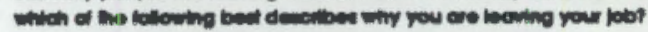

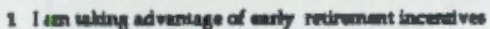

2 I tan ruting

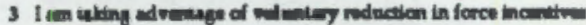

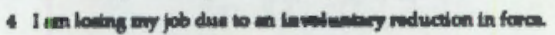

5 oter (pines repdy)

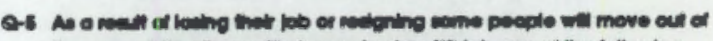

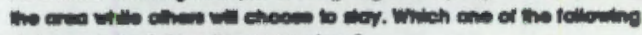

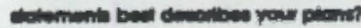

1 Iluve no deflutu plans at this time.

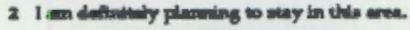

3 I an deffatwily plming to move cut of the eres.

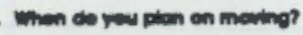

1 Whith the next monech

2 Writh the nea 2-3 manths

3 With the nes 46 monthe

4 Socnevime ofier 6 manthe

3 Dent know

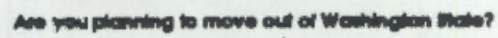

$1 \mathrm{Y}=$

2 No

3 Dont lenow

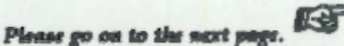

\section{FIGURE B.2. Redesigned Hanford Worker Exit Survey Form}




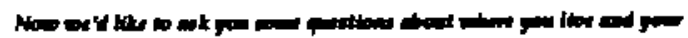

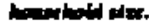

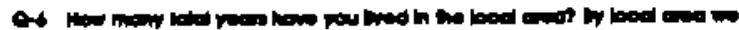

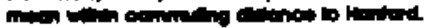

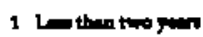

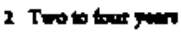

3 Anष

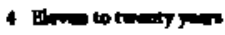

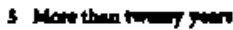

0)

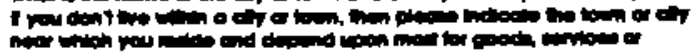

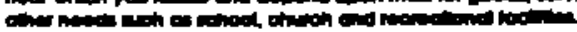

\section{Tom on Ory Crom}

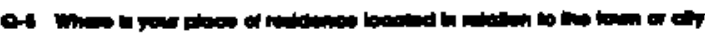

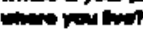

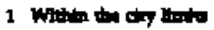

2 Ould the of the

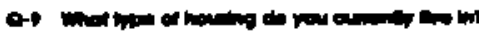

1 An Apratis

2 A Howe

3 A Tomber.

4 A Dor

5 A Motel Herm/trellar

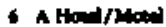

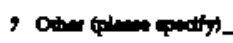

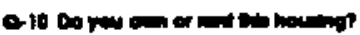

10 .

2 매

Now

1 The

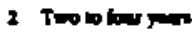

3 Pow to

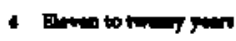

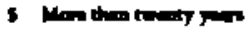

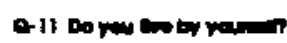

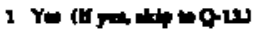

2 No

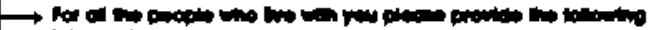
nomolion:

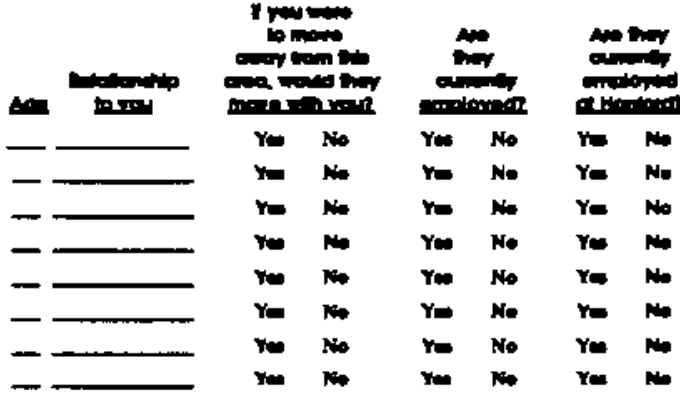

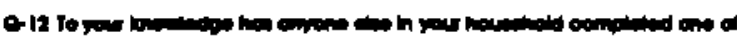

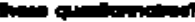

Tr ro

2 No

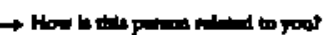

1 spone

2 Pre

3 and

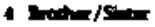

5 fim

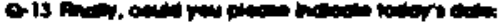

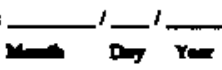

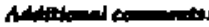

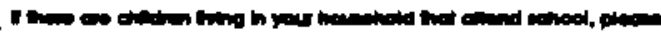

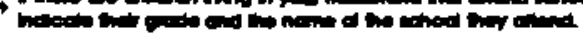
con
Nam of Solver
המשיח

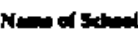

-

-

-

$-$

$-$

\section{FIGURE B.2. (contd)}


$\because$ 


\section{APPENDIX C}

DETAILS OF HANFORD EMPLOYMENT FORECAST 
APPENDIX C

\section{DETAILS OF HANFORD EMPLOYMENT FORECAST}

The economic and social impacts forecasted in this report depend to a large extent on the forecasts that DOE Richland Operations Office is able to make of budgets and required manpower for the Hanford Site. Table C.I contains the most recent official scenario concerning the future employment by mission at the Hanford Site. In the past, there has been a tendency among offsite analysts to treat these scenarios as "absolute," so several cautionary notes are in order. We note that these are scenarios or forecasts, not assured levels of activity. Budgetary and employment data for FY 1989 are still uncertain, pending future congressional action.

IABLE C.1. Forecast of Hanford Site Employment by Program, February 1988

\begin{tabular}{|c|c|c|c|}
\hline \multirow[b]{2}{*}{ Hanford (DOE and GOCO Contractors) } & FY 1987 & FY 1988 & FY 1989 \\
\hline & & & \\
\hline Materials Production & 6,400 & 5,100 & 4,100 to 4,200 \\
\hline $\begin{array}{l}\text { Defense Waste and Environmental } \\
\text { Restoration }\end{array}$ & 2,900 & 3,200 & 3,450 to 3,650 \\
\hline Basalt Waste Isolation Project & 1,300 & 200 & 50 to 50 \\
\hline Nuclear Energy R\&D (FFTF) & 1,300 & 1,300 & 1,300 to 1,400 \\
\hline Other Programs & 2,600 & 2,600 & 2,600 to 2,600 \\
\hline $\begin{array}{l}\text { Total Hanford Employment } \\
\text { (excludes construction) }\end{array}$ & 14,500 & 12,400 & 11,500 to 11,900 \\
\hline Annual Change & & $-2,100$ & -900 to -500 \\
\hline Cumulative Change & & $-2,100$ & $-3,000$ to $-2,600$ \\
\hline
\end{tabular}




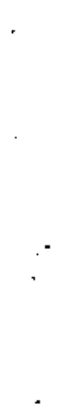




\section{DISTRIBUTION}

No. of

Copies

\section{OFFSITE}

10 DOE/Office of Scientific and Technica] Information

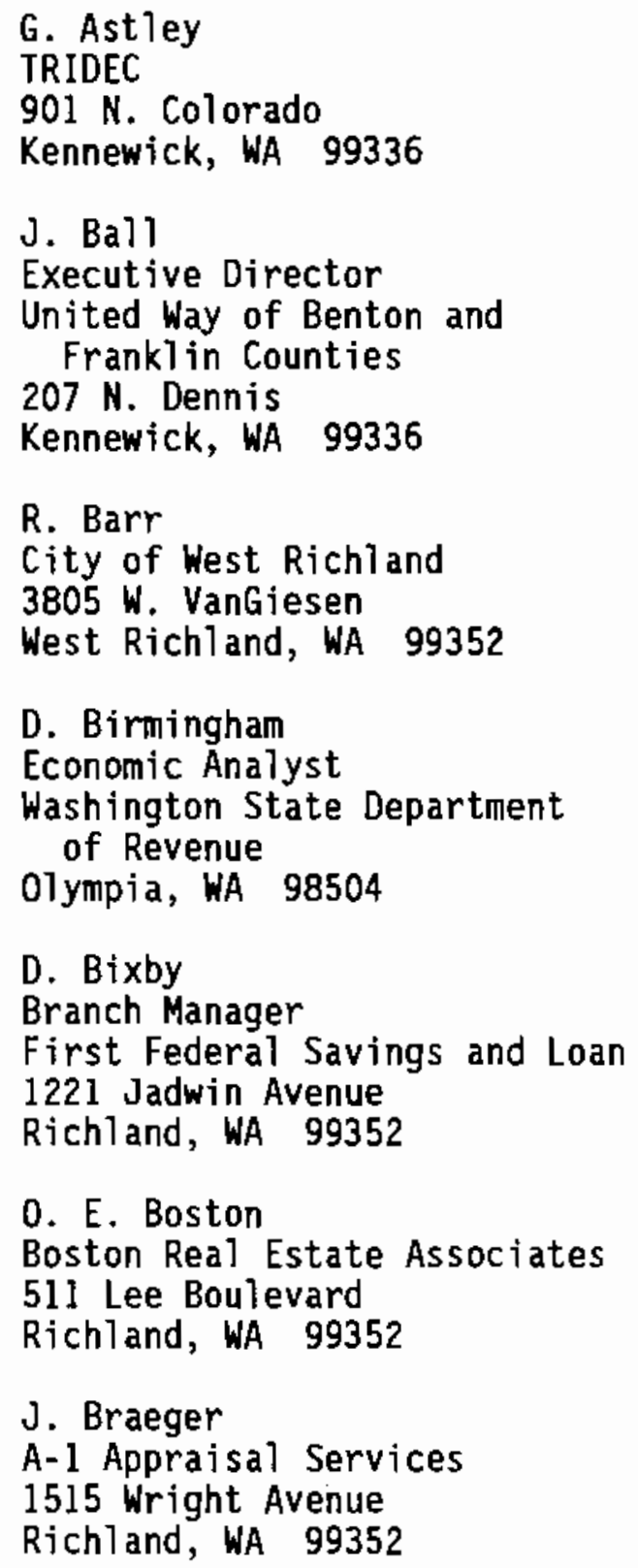

No. of

Copies

\author{
A. Bryant \\ Director \\ Tri-Cities Food Bank \\ 1301 Sacramento Boulevard \\ Richland, WA 99352 \\ R. Cantrel] \\ Corondelet Psychiatric Care \\ Center \\ 1175 Gribble \\ Richland, WA 99352 \\ D. E. Carlson \\ Richland School District \\ 615 Snow Avenue \\ Richland, WA 99352
}

L. Carlson

Financial Supervisor Washington State Department of Social and Health Services $800 \mathrm{~W}$. Court Street Pasco, WA 99301

\section{R. Chase}

Department of Trade and Economic Development General Administration Bujlding

Olympia, WA 98504

J. Conner

Finance Director

City of Pasco

P.0. Box 293

Pasco, HA 99301

G. Crutchfield

City of Pasco

412 W. Clark

Pasco, WA 99301 
No. of

Copies

R. Dean

Russ Dean Ford and Family RV Center

P.0. Box 2347

Pasco, WA 99302

D. Dillman

The Bon

400 Columbia Center Boulevard

Kennewick, WA 99336

R. Drake, Sr.

Benton County Commission

Courthouse

Box 190

Prosser, WA 99350

L. Dunbar

City of Richland Electrica? Services

505 Swift Boulevard

Richland, WA 99352

V. Erickson

Economic Development Partnership

18000 Pacific Highway South

Suite 400 , Tower 1

Seattle, WA 98188

R. Ferguson

TRIDEC

901 N. Colorado

Kennewick, WA 99336

J. Finigan

Tri-City University Center

100 Sprout Rd.

Richland, WA 99352

B. Fisher

City of Kennewick

210 W. 6th Ave.

Kennewick, WA 99336
No. of

Copies

R. Fleming

Branch Manager

Yakima Federal Savings and Loan

1007 Jadwin Avenue

Richland, WA 99352

Frankl in County Planning

Director

County Court House

1016 N. 4th

Pasco, WA 99301

M. Frazer

Administrator

Kennewick General Hospital

900 S. Auburn

Kennewick, WA 99336

L. Hammon, Fiscal Director

Pasco School District

1004 N. 16th

Pasco, WA 99301

H. J. Hansen, Superintendent

Kiona-Benton City School

District \#52

P.0. Box 488

Benton City, WA 99320

M. Henderson

TRIDEC

$901 \mathrm{~N}$. Colorado

Kennewick, WA 99336

$P$. Henderson

Henderson, Vining and Associates

8300 Gage Boulevard \#515

Kennewick, WA 99336

E. Hendler

City of Pasco

412 W. Clark

Pasco, WA 99301 
No. of

Copies

D. Holland

Department of Agricultural Economics

Washington State University

Pullman, WA 99164

J. Holman

Port of Benton

2952 George Washington Way

Richland, WA 99352

S. Kavanaugh

House Ways and Means Committee 216 House Office Building

01ympia, WA 98504

R. Kinnier

Office of Economic Adjustment

7500 Sandpoint Way N.E.

Seattle, WA 98115

L. Laffaw

Sears Roebuck

455 Columbia Center

Kennewick, WA 99336

R. Leedy, Director

Community Development Department

City of Richland, City Hall

505 Swift Boulevard

Richland, WA 99352

I. Lefberg

Office of Financial

Management

Insurance Building $\mathrm{AQ}-44$

07 ympia, WA 98504

L. Linder

GTE

P.0. Box 1003 3-EP

Everett, WA 98206
No. of

Copies

\author{
M. Lindsay \\ Tri-Cities Visitor and \\ Convention Bureau \\ 6951 W. Grandridge Boulevard \\ Kennewick, WA 99336
}

T. A. Marden

Planning Director

Benton County

P.0. Box 910

Prosser, WA 99350

H. Mathews

Frankl in County Commission

1016 N. 4th

Pasco, WA 99301

K. Matzkin

Office of Economic Adjustment

Office of Assistant Secretary of Defense

Room 4C767,

The Pentagon

Washington, DC 20301-4000

B. McCurley

Bi11 McCurley Chevrolet

P.0. BoX 2698

Pasco, WA 99302

R. McVicker

Housing Gui]d, Inc.

8300 Gage Boulevard

Kennewick, WA 99336

R. Menasco

City of West Richland

City Hall

3805 W. Van Giesen

West Richland, WA 99352

L. Miller

Tri-City Board of Realtors

7151 W. Clearwater Avenue

Kennewick, WA 99336 
No. of

Copies

R. Mussen

Support Services

City of Richland

Richland, WA 99352

R. Noland

City of Kennewick

P.0. Box 6108

Kennewick, WA 99336

J. 01son, Director

Ben-Franklin Transit

1000 Columbia Drive S.E.

Richland, WA 99352

Our Lady of Lourdes Hospita1

Administrator

520 N. 4 th

Pasco, WA 99302

J. Painter

City of Kennewick

210 W. 6th Ave.

Kennewick, WA 99336

M. Padelford

Department of Social and Health Services

$800 \mathrm{~W}$. Court

Pasco, WA 99301

J. Pennington, Forecaster

Pacific Northwest Bell

421 S.W. Oak Room 452

Portland, OR 97204

J. Poynor

City of Richland

505 Swift Blvd.

Richland, WA 99352

Director

Private Industries Counci]

$6515 \mathrm{~W}$. Clearwater

Kennewick, WA 99336
No. of

Copies

R. Robinson

Ferguson and Associates

7601 W. Clearwater

Kennewick, WA 99336

J. Sanders

Benton Co. P.U.D.

P.0. Box 6270

Kennewick, WA 99336

D. Schau

Department of Employment Security

3900 West Court Street

Pasco, WA 99301

S. Scheran

House Ways and Means Committee

216 House office Building

$07 y m p i a$, WA 95804

N. Schulman

City of Richland

505 Swift Blvd.

Richland, WA 99352

M. Schwenk

TRIDEC

901 N. Colorado

Kennewick, WA 99336

M. Shumate

Shuntate Pontiac-Cadillac-Mazda

P.0. Box 3229

Pasco, WA 99302

15 D. Silver

Office of the Governor

Insurance Building, $\mathrm{AQ}-44$

01ympia, WA 98505

T. Stegbauer

Associate Administrator

Kadlec Medical Center

888 Swift Boulevard

Riclitand, WA 99352 
No. of

Copies

J. Taylor

Department of Housing and Urban Development

Mail Stop 10-SRM

1321 2nd Avenue

Seattle, WA 98101

T. Thompson

Associated Appraisers

1613 Dawes

Kennewick, WA 99336

P. Vick

Port of Pasco

$904 \mathrm{E}$. Ainsworth

Pasco, WA 99301

S. Volpentest

TRIDEC

901 N. Colorado

Kennewick, WA 99336

J. L. Walker

Kennewick School District \#17

200 S. Dayton Street

Kennewick, WA 99336

S. Watkins

Port of Kennewick

1 Clover Island

Kennewick, WA 99336

M. Weiss

Columbia Basin College

2600 N. 20th

Pasco, WA 99301

R. Zengerle

Benton County Treasurers Office

Prosser, WA 99350

\section{ONSITE}

58 DOE Richland 0perations Office

J. S. Abernethy

J. D. Kautzky
No. of

Copies

E. C. Norman

J. E. Ollero

J. L. Rhoades

A. J. Rizzo

R. M. Rosselli

R. R. Tibbatts

K. J. Wheeless (50)

Hanford Environmental Health Foundation

B. D. Breitenstein

Kaiser Engineers Hanford

R. T. French

6 Westinghouse Hanford

G. Belew

J. G. Burk

A. R. Hawkins

J. E. Nolan

S. A. Weber

47 Pacific Northwest Laboratory

R. C. Adams

J. F. Bagley

D. B. Belzer

D. B. Cearlock

J. W. Currie

A. F. Johnston

D. K. Kreid

R. C. Liikala

R. P. Marshall

T. A. Nelson (25)

R. W. Schultz

M. J. Scott (2)

E. J. Stenehjem

J. W. Thielman

W. R. Wiley

Publishing Coordination MH (2)

Technical Report Files (5) 


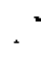




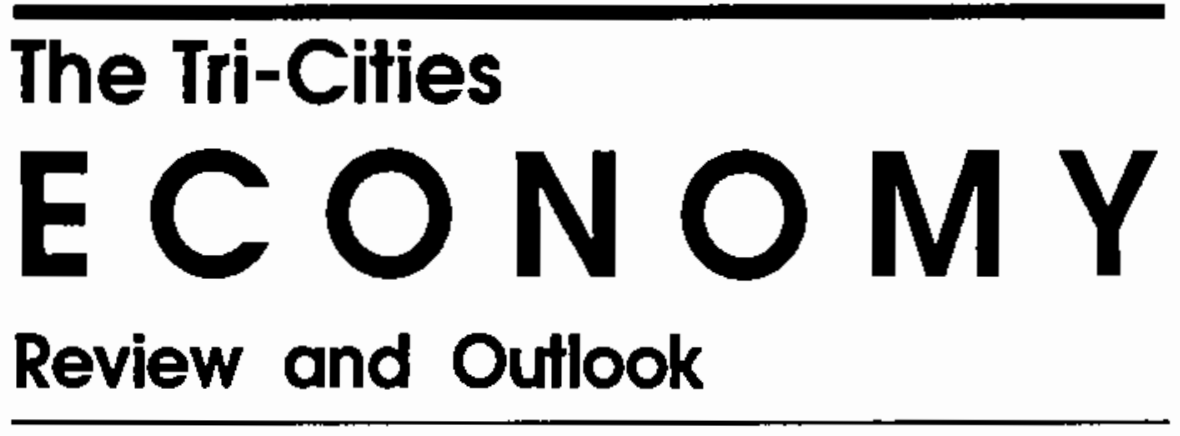

March 1989 Summary 


\section{Preface}

The economies of the Tri-Cities (Richland, Kennewick, and Pasco) and Washington State are being adversely affected by the cutbacks in employment at the federally operated Hanford Site. In an effort to monitor and assess this situation and provide local and state leaders information to plan and respond most effectively, the Department of Energy's Richland Operations Office and the Department of Defense's Office of Economic Adjustment are jointly funding the Pacific Northwest Laboratory to accomplish an economic assessment study. This report reviews recent economic developments in the Tri-Cities and presents a look ahead, through 1989 . This information is intended to help readers understand and adjust to changes in the local economy.

Every six months through 1991, we plan to update this report to provide a continuing record of events in the changing Tri-Cities economy. It is our intent that this ongoing monitoring and analysis of the economy will be useful to local citizens, businesses, and others with an interest in the Pacific North west and the Tri-Cities. 


\section{Summary}

Through 1988, Hanford lost 2200 bicounty resident jobs. As noted in the N Reactor Closure Study of 1987, for each Hanford job lost, about 1.2 additional local secondary or service sector jobs are eventually lost over a period of approximately 4 years. In the first year (1988), the negative economic effects expected from the Hanford job losses were moderated by the growth in the non-Hanford basic sector. However, in 1989 we expect the Tri-Cities economy to weaken further. This is primarily due to limited growth foreseen in the non-Hanford basic sector, additional Hanford job losses, and the secondary sector responding to both the job losses that occurred in 1988 and the additional job losses in 1989.

The following tables summarize the results of our monitoring of the Tri-Cities economy in 1988 and our forecast for 1989 .

\section{ECONOMIC HIGHLIGHTS 1988 Benton and Fronklin Counties \\ Total Employment Down-2,250 since third quarter 1987 \\ Personal Income Down-2\% since 1987 \\ Population Down-600 by Aprll 1, 1989 \\ Housing Prices Down-2.5\% since 1987}

\section{FORECAST HIGHLIGHTS 1989 \\ Benton and Fronkin Countles}

Total Employment Down-550 to 1050

Personal income Down-0.9\% to $1.5 \%$

Population Down-700 to 900 by April 1, 1990

Housing Prices Down-1\% to $2 \%$ 
Recent losses at Hanford interrupt a slow recovery of the Tri-Cities economy.

\section{Tri-Cities in the 1980s}

In the early 1980 s the Tri-Cities was one of the fastest growing metropolitan areas in the United States as the Washington Public Power Supply System was building three nuclear power plants simultaneously on land just north of Richland. This construction boom came to a halt in 1982 as work stopped on two of these reactors.

Overall employment in Benton and Franklin counties peaked in 1981 at about 76,000 jobs. By 1984, total employment had fallen by over 16,000 jobs.

Meanwhile, jobs at Hanford for the Department of Energy and its contractors were growing in number, especially in nuclear materials production (producing plutonium for the Nation's defense). In the next three years (1985 through 1987) the economic climate improved. The number of people working in the TriCities began to increase slowly, so that by 1987 about 4,000 of the lost jobs were recovered. But in 1988 major cutbacks at Hanford once again applied the brakes to local economic growth.

\section{Hanford-The Year in Review}

The fall of 1987 through the winter of 1988 was a time of transition for the Tri-Cities - a time of adjusting to new economic realities at the nearby Hanford site.

The latest economic trouble began in December 1987 when the Basalt Waste Isolation Project (BWIP) abruptly ended. That unexpected announcement was followed in February 1988 by the announcement that the $\mathrm{N}$ Reactor would be placed in cold standby, due to reduced national defense demand for its main product-plutonium. 


\section{Job Losses of Hanford}

While the BWIP-related job loss was swift and final, the loss of N Reactor and potential loss of additional nuclear materials production jobs is not over.

Job losses in FY 1988, and additional job losses in FY 1989 and thereafter are expected to have lingering effects as the nuclear materials mission winds down over the coming years.

Benefitting from the 1980s defense buildup, Hanford jobs had been at about 14,500 at the end of Federal fiscal year (FY), September 30, 1987. One yeur later, September 30, 1988, employment at Hanford was down to 12,400 . By the end of calendar year ( $\mathrm{Cr}$ ) 1988 , total Hanford jobs measured 12,200 . Of the total 2,300 drop, 2,200 were residents of Benton and Franklin Counties.

\section{Dtversity Honford, But How?}

Meanwhile, the Department of Energy (DOE) and its major Hanford contractors, including Westinghouse Hanford Company (Westinghouse Hanford), which operated both BWIP and N Reactor, Battelle Northwest, which operates the Pacific Northwest Laboratory (PNL), and with the support of Kaiser Engineers Hanford (KEH) and the Hanford Environmental Health Foundation (HEHF), are attempting to diversify Hanford by taking on new research in areas as diverse as space power, environmental research and molecular science.

Westinghouse Hanford, while continuing to manage operations on the Hanford Site, including the Fast Flux Test Facility (an advanced test reactor), deferise waste cleanup and storage programs, and the declining production program, is focusing increased attention on isotope production and space power systems. PNL is pursuing the establishment of an Environmental Center of Excellence and a Molecular Science Research Center, in response to two DOE research

Hanford total bi-county resident job losses through the end of CY 1988 were 2,200 .

END-OF-QUARTER

\section{HANFORD}

\section{EMPLOYMENT BY} MISSION
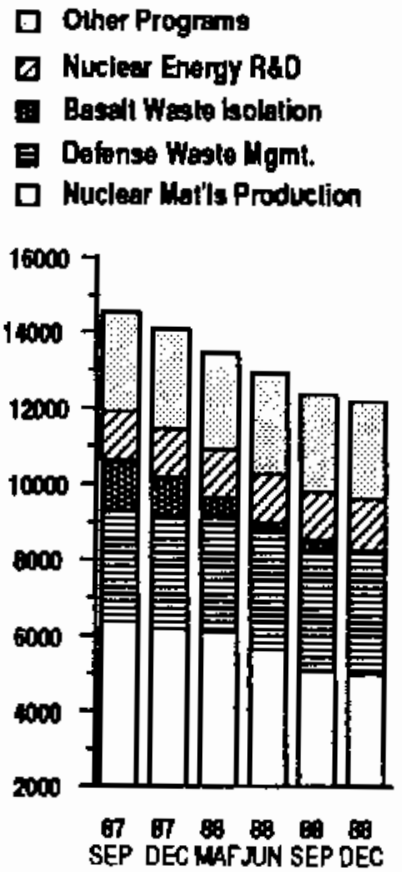
New research

areas, operation

of the Fast Flux

Test Focility and

defense waste

cleanup are key

elements to future

Hanford

diversificotion. interests environmental research and basic research in materials and energy resources. Both interest areas would significantly diversify the Hanford Site research mission.

One likely element in any Hanford recovery that is expected to combine research, construction, and operations is to clean up existing nuclear wastes created during more than 40 years of defense production. The effort is needed and has broad public support. Proposed Hanford budgets show growth in this area, somewhat offsetting the substantial declines in defense materials production and the elimination of BWIP.

\section{The Tri-Cities Area in 1988}

The Tri-Cities felt the impact of Hanford cutbacks on jobs, income, housing, population and school enrollment in 1988. Fortunately, it was not as severe as originally anticipated due to unexpected strength in the non-Hanford economy and a reduced level of Hanford layoffs. How long the good news can offset the bad is highly contingent upon growth in other major sectors outside of Hanford. But it seems likely that the efferts of Hanford cutbacks will begin to be more evident in 1989 (see What's Ahead for Jobs).

\section{Jobs Through December 1988}

After increases in the number of jobs in 1986 and stability in 1987, total jobs in Benton and Franklin Counties declined sharply in 1988 due to the Hanford layoffs. Total resident employment dropped by 2,250 between the third quarter of 1987 and the fourth quarter of 1988 , on the basis of seasonally adjusted quarterly average figures.

Use of seasonal adjustment and quarterly averages smoothes out many of the month-to-month variations caused by factors such as weather and the 
Christmas retail season, giving a clearer picture of underlying changes in the economy. The chart on the following page focuses on those workers resident in the two counties.

In examining employment changes in Benton and Franklin Counties, the underlying analysis in this report distinguishes between a basic sector of the economy and a secondary or service sector. The basic sector includes those businesses that sell goods and services outside of the bi-county area. Hanford (DOE and its major contractors) is the largest single component of the basic sector. The non-Hanford basic sector includes agriculture and major employers such as the Washington Public Power Supply System, Advanced Nuclear Fuels and Sand vik Spexial Metals. The secondary sector is essentially a support sector. It sells goods and services locally to those involved in the basic sector and others in the secondary sector. The secondary sector would include most of retail trade, services, construction, local schools, and city and county govemment workers.

The chart on the following page shows that resident Hanford employment, on a quarterly average basis, dropped by about 2,200 jobs between the third quarter of 1987 and the fourth quarter of 1988 (about 13,450 to 11,250). Non-Hanford resident basic employment increased by about 450 over the same period, while secondary sector resident employment declined by about 500 .

\section{The Effects of Non-Hanford Growth in 1988}

Economic growth outside of Hanford was strong in 1988. Key factors offsetting the economy-wide impact of Hanford job losses were higher farm prices, expansion of retailing activity in and around Columbia Center, relocation of Lamb-Weston headquarters, a new coliseum, and increases in transfer payments to retirees (reflecting real growth in the region's retire population). 
important areas of non-Hanford growth included agriculture, retirees, expanded regional retailing. a new coliseum. and LambWeston headquarters.
It was widely feared that job losses in the secondary sector would be severe during 1988 in the face of the substantial layoffs at Hanford. As noted earlier, the methodology employed in PNL's 1987 study of a possible N Reactor closure suggests that for each Hanford job lost, approximately 1.2 additional local secondary sector jobs are eventually lost over a period of four years. Consequently, with the loss of 2200 Hanford jobs through CY 1988 and with no other changes in the non-Hanford basic sector, nearly 2,650 local secondary or service jobs could eventually be lost. Of the 2,650 , about 1,000 jobs were expected to have been lost by the end of 1988 .

\section{BENTON AND FRANKUN COUNTY AVERAGE QUARTERLY EMPLOYMENT BY MANOR SECTOR (Seasonally Adjusted)}

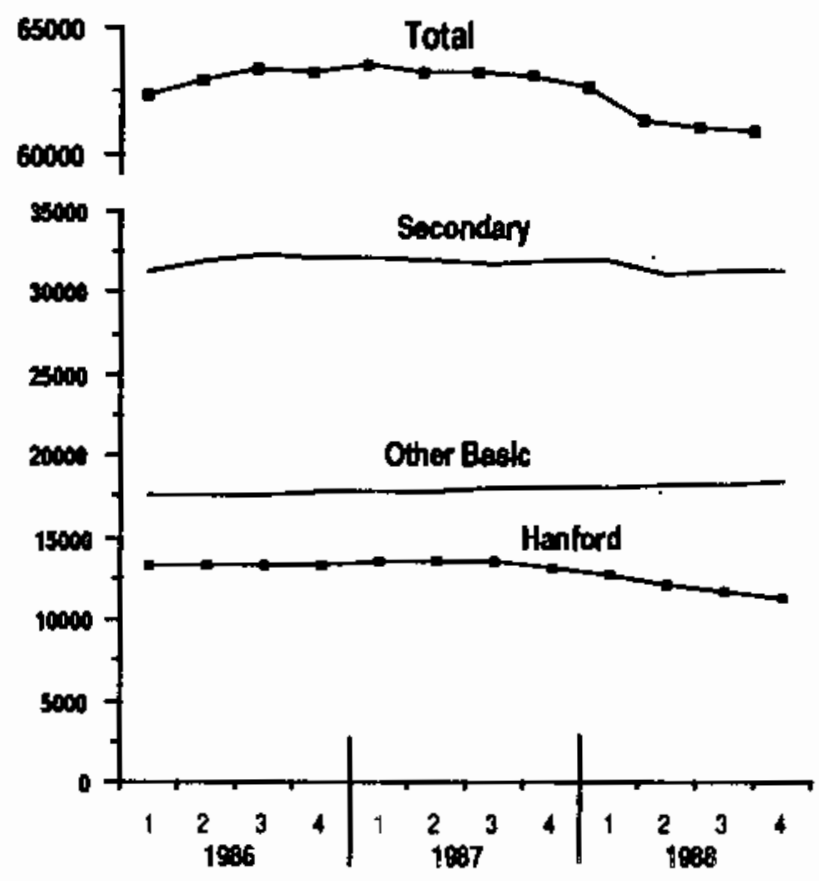


Fortunately, the positive developments in the remainder of the economy offset about 500 of these potential job losses during the year. Continued significant growth in the non-Hanford sector or an upturn in Hanford's programs will be required to offset the lingering effects of the 1988 Hanford losses, as well as to counteract any further reductions at Hanford.

\section{Income Estimates For 1988}

Personal income in the Tri-City area (Benton and Franklin Counties) is estimaked to have been about $\$ 2.10$ billion in 1988, a decline of a little more than 2 percent from 1987 after adjustment for inflation. Personal income is perhaps the best measure of total purchasing power of the area's local population. Personal income includes wages and salaries, farm income, transfer payments such as social security, and dividends and interest income. The drop in personal income in 1988 stemmed primarily from the loss of Hanford payroll, but the impact of Hanford was partially offset by growth in other components.

Total wage and salary income declined from $\$ 1.40$ billion in 1987 to around $\$ 1.34$ billion in 1988 (again, after adjusting for inflation) which was a $4.3 \%$ decline, estimated increases in farm income and government payments to retires helped to cushion this loss.

Famm income is estimated to be up sharply in 1988 (between $\$ 5$ and $\$ 10$ million) over the previous year. Prices are higher for wheat, potatoes, and apples, key mid-Columbia commodities.

Transfer payments to retirees in the region increased by about $\$ 5$ million over the previous year. The number of retirees continues to increase. In addition, approximately one-sixth of the people who lost jobs at Hanford took advantage of early retirement programs, and over two-thirds of these people intend to stay in the Tri-Cities, according to surveys of exiting Hanford workers. This group helps maintain regional purchasing power.
Declines in wage and salary income were partially offset by increases in farm income and retiree transfer payments. 


\section{AVERAGE SELLING PRICE OF SINGLE- FAMILY HOME (\$thousands)}

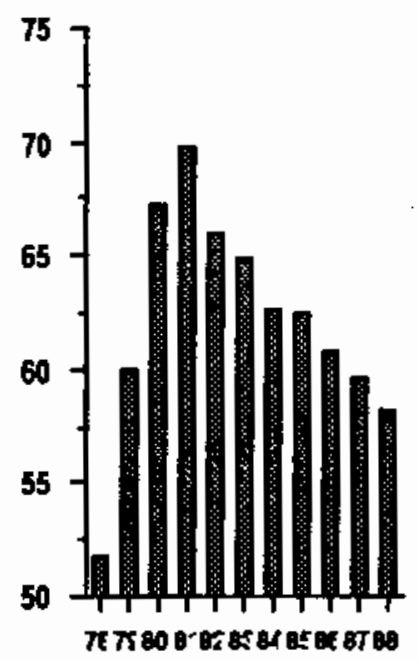

\section{BENTON AND FRANKLIN COUNTY POPULATION (April 1)}

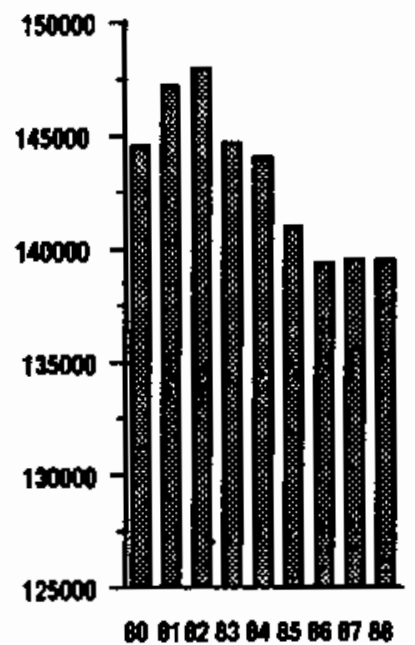

Income losses at Hanford totaled about $\mathbf{\$ 5 0}$ million during 1988 , as compared to 1987 . This was partially offset by $\$ 5$ to $\$ 10$ million in agriculture, and additional spending by retirees and tourists.

\section{Housing}

Housing values have been in decline since the Supply System slowdown. In 1988, average single family housing prices were actually lower than in 1979. Prices continued a slow decline during the first half of 1988 , although there were signs of stability and increase by year's end.

\section{Population and Schools}

Through the first part of 1988, total population in Benton and Franklin Counties was nearly 140,000, essentially unchanged from the previous two years. Population figures are based on annual estimates of population as of April 1. This leveling follows a fiveyear decline from a peak of nearly 148,000 in 1982. The rapid growth in population in the 1970s had changed to declines after the 1982 Supply System slowdown.

The available data indicate that births in the local area exceeded deaths by approximately 1,500 . The State's Office of Financial Management estimates no change in total population between April 1987 and 1988, which suggests probable outmigration.

Although some of this outmigration can be altributed to the first round of job losses at Hanford, the remainder likely is due to other factors. State population data were available only through A pril 1. Based on telephone subscriber data through September, we estimated outmigration of almost 1,200. This loss was most heavily concentrated in Richland. The 1988 outmigration indicates a possible net population loss in the last half of the year. By April 1, 1989 we expect the net loss in population to be about 600 . 
Consistent with the estimated population drop in Richland, school district enrollment in that city declined by 240 students in the past year. However, Kennewick and Pasco enrollments were up a total of 130 students. The relationship between enrollments and population is still unclear and we are continuing to evaluate it.

\section{The Outlook for 1989}

The experience through the third and fourth quarters of calendar year 1988 indicates that Hanford job cutbacks were offset somewhat by a stronger nonHanford basic sector. However, in 1989 the Hanford impacts are expected to increase in size, while nonHanford basic sector activity is not expected to be strong enough to offset the impacts. Without additional substantial increases among non-Hanford employers or at Hanford itself, this employment decline will continue into $\mathbf{1 9 9 0 .}$

\section{BENTON AND FRANKLN COUNTY AVERAGE RESIDENT EMPLOYMENT BY QUARTER}

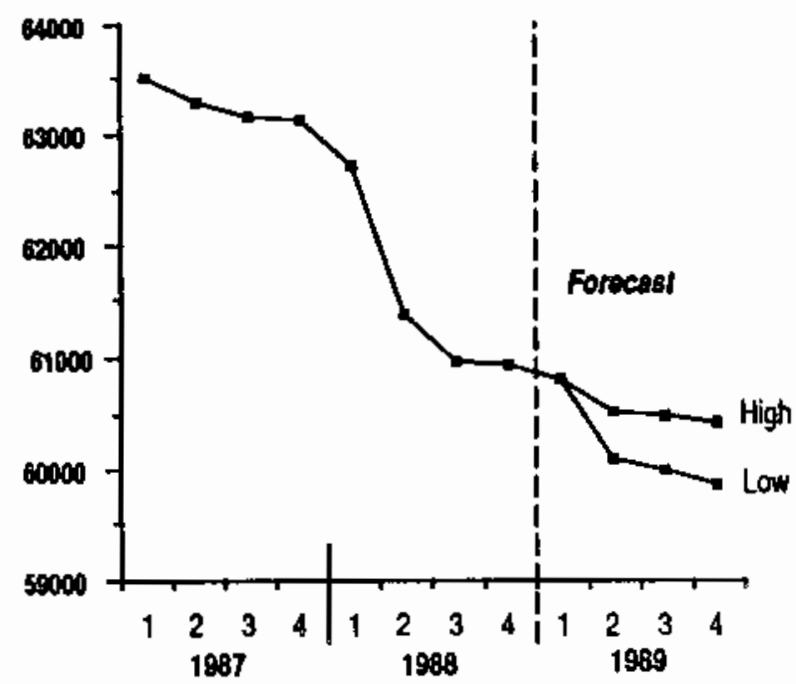


Total area

employment is

projected to foll

by 550 to 1050

jobs during

CY 1989.
CHANGE IN BENTONFRANKLIN COUNTY EMPLOYMENT BY SECIOR (Fourth Quorter 1988 to Fourth Quarter 1989)

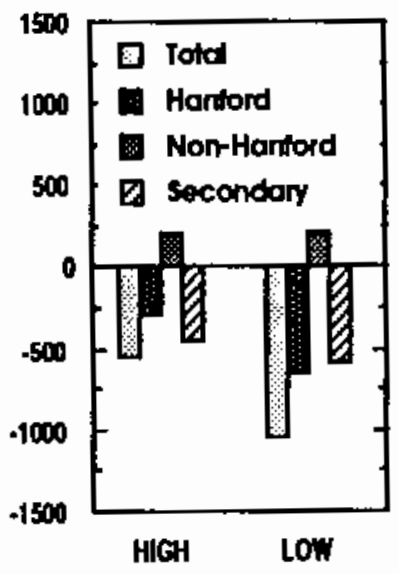

\section{What's Ahead for Jobs}

As the year 1988 illustrates, predicting short term changes in jobs is difficult. To predict changes in 1989 jobs, we assumed the following:

- The removal of fuel from the N Reactor leads to further declines in Hanford jobs. These declines are only partially offset by moderate growth in defense waste and environmental restoration activities. Department of Energy estimates a loss of between 500 and 900 jobs between September 1988 and the end of the federal fiscal year in September 1989. On a quarterly average basis, this translates into a loss of 300 to 650 Hanford job slots for residents of Benton and Franklin counties during calendar year 1989. (Significant additional funding for environmental restoration is currently pending Congressional action.

Approval would favorably influence the current employment forecast.)

- The farm economy remains strong but does not grow further.

- Food processing employment increases by 100 as the new Cascade Columbia food processing plant starts operation.

- Little increase at other major employers (approximately 50 jobs).

- About 200 of the 1988 jobs associated with the Columbia Center expansion are assumed to be part of the community's "export" sector, that is supported by shoppers outside the Tri-Cities. This number is assumed to grow about $25 \%$ in 1989.

- Total government payments to retirees increase by about $3.5 \%$, as in recent years.

Based upon the assumptions above, total nonHanford basic employment is projected to increase by about 200 between the fourth quarter of 1988 and the fourth quarter 1989. The secondary sector, however, will continue to experience job losses from the 
ongoing repercussions of the 1988 Hanford losses, plus the expected Hanford reductions during 1989. Assuming the lower number of 1989 resident Hanford reductions, secondary employment is expected to fall by 450 . Total area employment in this case falls by 550 ( -300 at Hanford, +200 in other basic, -450 secondary). Using the higher estimates of Regional personal income will decline for $a$ second straight year. Hanford job losses, total Benton Franklin County employment is projected to fall by 1,050 ( -650 Hanford, +200 other basic, -600 secondary).

\section{Income and Spending Oullook}

Based upon the employment projections for 1989, regional personal income is expected to fall by an additional $0.9 \%$ to $1.5 \%$ in 1989 after inflation.

Farm income is expected to remain high for the second year in a row but not increase sharply as in 1988. A growing retirement population will be primarily responsible for a $3 \%$ to $4 \%$ increase in government transfer payments in 1989.

A reduction in total personal income should be reflected in retail sales and housing markets. A drop in retail sales and construction activity should result in reduced tax revenues.

Although retail sales and sales tax revenues may decline in proportion to personal income, other factors could upset this relationship. For example, new businesses may be attracted to the Tri-Cities. Additional retail sales to people outside the Tri-Cities may increase the sales-related receipts of state and local govemments beyond what locally eamed incomes would support. Alternatively, additional layoffs at Hanford may make remaining Hanford workers into more cautious consumers - concerned about their own jobs. They might reduce spending and increase savings. 
Housing prices will fall slightly in 1989. Population will likely fall during 1989 , but the magnitude of the decline is uncertain.

\section{Housing}

Average housing prices, which dropped about $2.5 \%$ in 1988 from the previous year, ane expected to decline another $1 \%$ to $2 \%$ in 1989 . However, low cost of land and housing though generally undesirable for existing horneowners, is a positive factor for outside businesses considering new locations. Low housing prices may also attract additional retires into the area.

\section{Population Outlook}

As in the mid-1980s, the Tri-Cities area faces the prospect of renewed declines in total population over the next few years. If fewer job opportunities exist, more workers and their families will end up leaving the area.

We expect that enough people will leave so that population will slightly decline despite more births than deaths.

By April of 1989, we estimate that total bi-county population will have dropped by about 600 from a year earlier. By 1990 , there may be an additional decline of between 700 and 900 people, leaving slightly more than 138,000 people in Benton and Franklin counties. Over half of the decline over these two years will occur in Richland.

These projections, however, are more uncertain than er.ployment projections. The 1982 slowdown showed that many families have considerable flexibility in deciding when to permanently leave the area. Lower housing prices and programs to lure retires into the area may also make the population losses smaller than discussed above.

\section{Conclusion}

In summary, while the Tri-Cities did experience signifcant exonomic impacts during 1988, the economy did not experience as severe a downturn as had been anticipated. This was due largely to the unexpected strong growth in the non-Hanford basic sector as well as the reduced level of Hanford layoffs. However, for 1989, the non-Hanford basic sector growth is expected to only 
partially offset the growing impact of Hanford job losses. The impacts associated with the 1988 Hanford job losses as well as those occurring in 1989 have yet to play themselves out fully in the local economy. We expect employment, population, income and real estate values to be weaker a year from now.

A strong and successful diversified growth in both the non-Hanford and Hanford basic sertor will be crucial to mitigating the impacts of the near term Hanford losses. The local area displays the momentum and hopeful signs of a long-term rebound as diversification proceeds. The Tri-Cities will noed to sustain that momentum.

\section{Acknowledgments}

This report is published by Pacific Northwest Laboratory, Richland Washington 99352.

Manager, Technology and Market Systems: Erik Stenehjem

Economic Analyst: Michael Scott and David Belzer

The detailed data and methodology on which this summary is based is published in a longer technical report, Hanford and the Tri-Cities Eomomy: Review and Outlook, March 1989, produced by M. J. Scott, D. B. Belzes, S. J. Marsh, D. M. Beck, R. W. Schultz, and S. A. Harkreader, Pacific Northwest Laboratory, Richland Washington, 99352.

We want this report to be useful as a planning tool, and would appredate any suggestions for improvement to its content. Please send your comments to: Mr. James Kautzky, Strategic Planning, U.S. Department of Energy, A1-55, Richland Operations Office, Richland, Washington 99352 , Telephone (509) 376-2801.

\section{Disclaimer}

This report was prepared as an account of work sponsored by an agency of the United States Covernment. Neither the United States Government nor any agency thereot, nor Battelle Memorial lnstitute, nor any of their employees, makes any warranty, expressed or implied, or assumes any legal liability or responsibility for the accuracy, completeness, or usefulness of any information disclosed. The views and opinions of authors expressed herein do not necessurily state or reflect those of the United States Government. 
